\title{
Geology of the
}

Bridgewater Quadrangle

Aroostook County, Maine

GE L OG ICAL S URVEY B ULLETIN 1206 


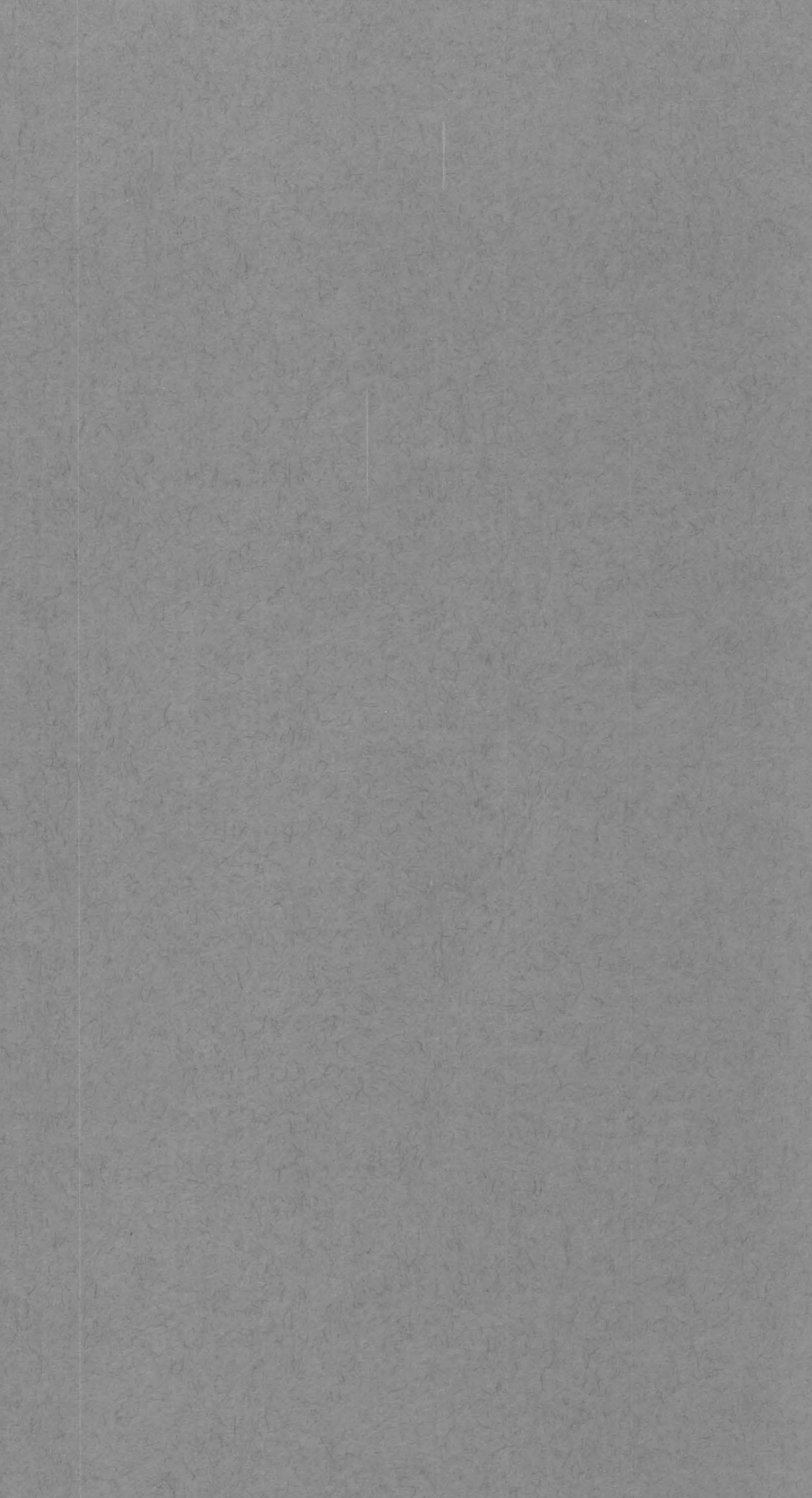




\section{Jeology of the}

\section{Bridgewater Quadrangle}

\section{Aroostook County, Maine}

$y$ LOUIS PAVLIDES

With a section on GEOPHYSICAL SURVEYS

$\begin{array}{llllllllllllllll} & \text { E O L O G I C A L S U R V E Y B U L L E T I N } 1206\end{array}$

Description of the geology of a laciated terrane of folded and veakly metamorphosed lower aleozoic rocks in northeast Maine

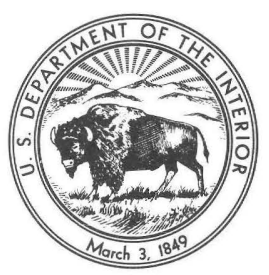


UNITED STATES DEPARTMENT OF THE INTERIOR

STEWART L. UDALL, Secretary

GEOLOGIGAL SURVEY

THOMAS B. NOLAN, Director

Library of Congress catalog card No. GS 65-309 


\section{CONTENTS}

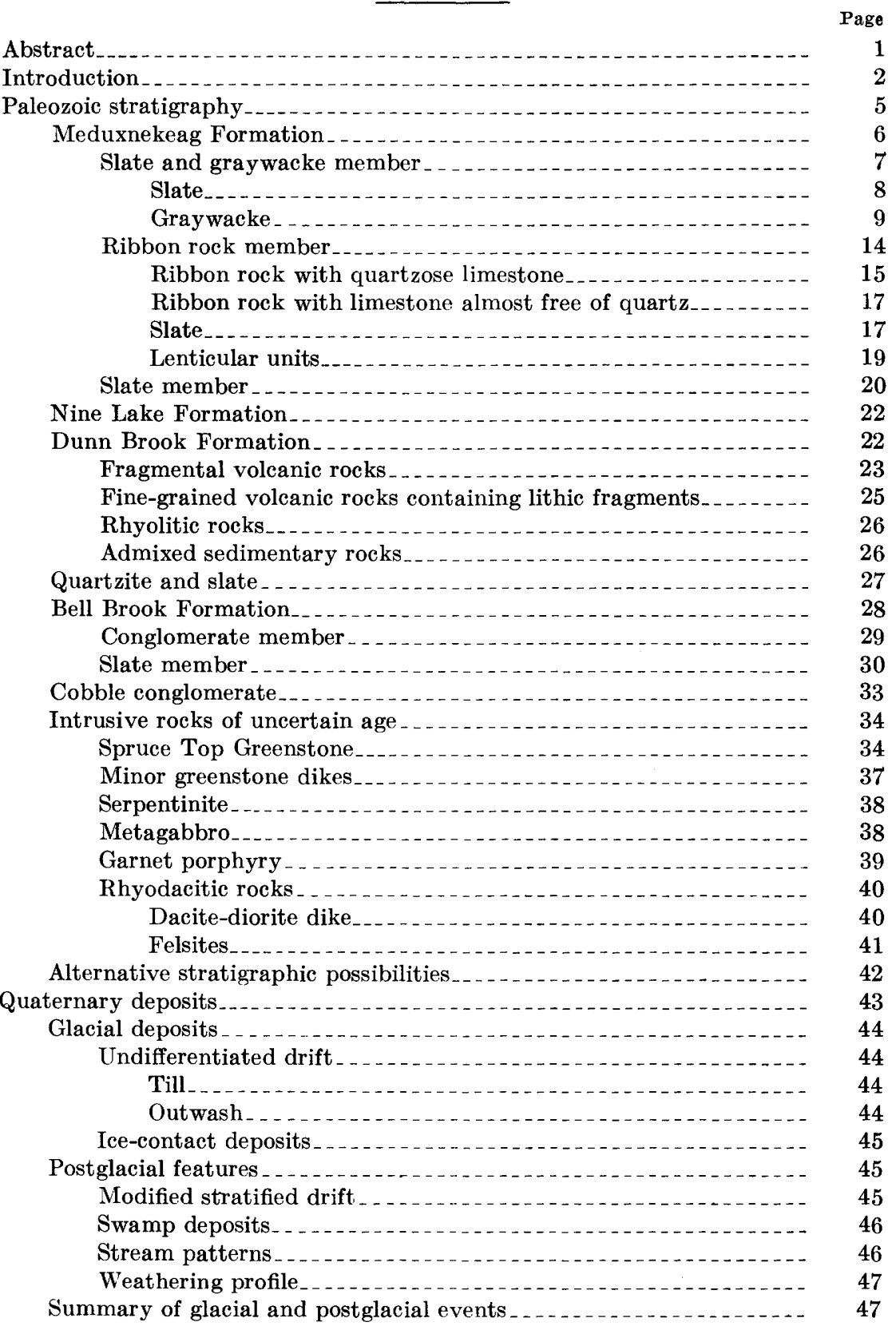




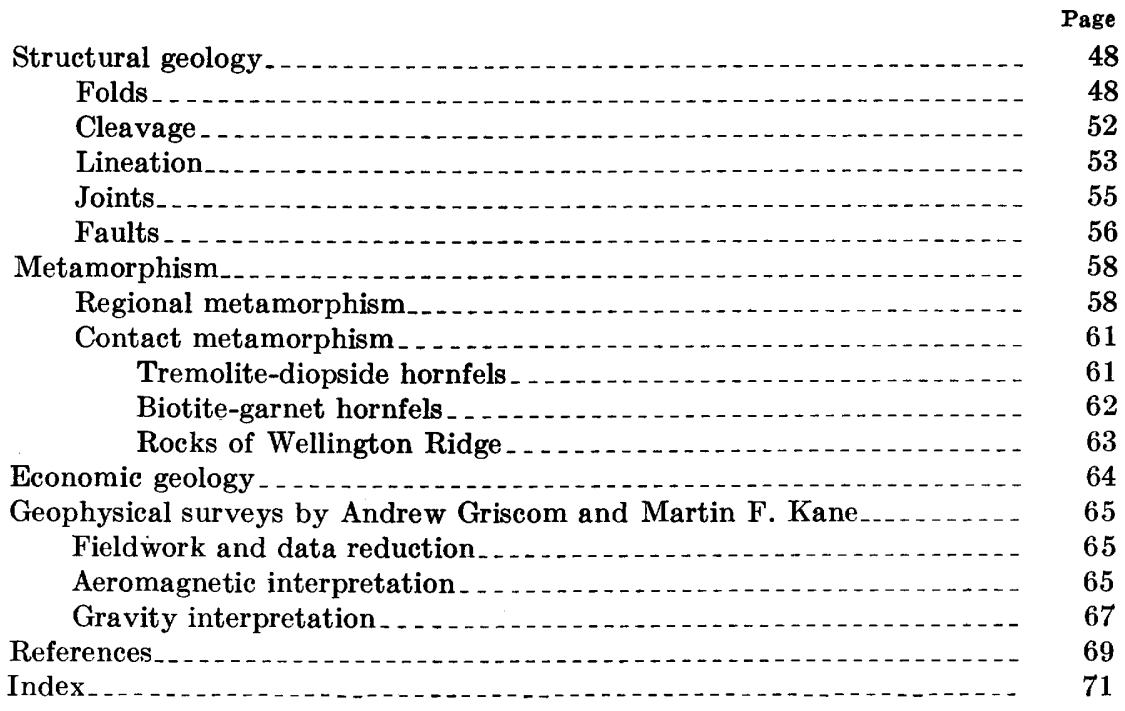

\section{ILLUSTRATIONS}

[Plates are in pocket]

Plate 1. Bedrock geologic map and sections of the Bridgewater quadrangle, Maine.

2. Sketch map of major glacial features, Bridgewater quadrangle, Maine.

3. Aeromagnetic and Bouguer gravity map of the Bridgewater quadrangle, Maine.

Figure 1. Index map showing the Aroostook manganese belt and the position of the Bridgweater and nearby quandrangles, Maine

2. Classification of graywacke

3. Photomicrographs of graywackes from the slate and graywacke member of the Meduxnekeag Formation. . . . . . . . .

4. Convolute layering in ribbon limestone of the Meduxnekeag Formation.

5. Photomicrographs of impure carbonate rocks from the ribbon rock member of the Meduxnekeag Formation ..........

6. Photomicrograph of a mixed volcanic conglomerate and breccia.

7. Photomicrograph of a fragmental volcanic rock containing volcanic chips

8. Geologic sketch map of the road-metal quarry along U.S. Highway 1 , Monticello Township, Maine

9. Small shear fold formed by differential slip of rock slices along cleavage planes.

10. Incipient slip cleavage formed in slate layer

11. Horizontal view of generalized sketches of fracture cleavage and fold relationships in ribbon rock of the Meduxnekeag Formation. 
FIGURE 12. Schematic diagrams of intrastratally refracted cleavage

13. Pencil lineation in calcareous rocks of the Medusnekeag Formation

14. Lineation band in slaty calcareous rocks of the Meduxnekeag Formation

15. Photomicrograph of feathery quartz growths at the ends of pyrite crystals in calcareous slate.

16. Tension joints in quartzose limestone layers enclosed between less brittle limy beds of the Meduxnekeag Formation......

17. Photomicrograph of spotted hornfels from Estabrook Hill_...-

\section{TABLES}

TABLE 1. Approximate thicknesses of stratigraphic units, Bridgewater quadrangle, Maine.

2-5. Modal analyses:

2. Graywacke from the slate and graywacke member of the Meduxnekeag Formation..................

3. Graywacke from quartzite and slate unit.

4. Graywacke from the Bell Brook Formation........

5. Greenstone from the Spruce Top Greenstone from Collins Ridge and Nineteen Mountain.......... 



\title{
GEOLOGY OF THE BRIDGEWATER QUADRANGLE AROOSTOOK GOUNTY, MAINE
}

\author{
By Louts Pavlmes
}

\begin{abstract}
Glacial deposits of various types cover most of the Bridgewater quadrangle in eastern Aroostook County, Maine. Outwash that has a thin modified upper zone and apparently rests directly on bedrock underlies most of the eastern part of the quadrangle. Till has been recognized only locally in the western part of the area. Ice-contact deposits occur chiefly in the southwestern part of the region where kame and kettle topography typifies kame fields and narrow sinuous, interrupted ridges (eskers) are distinctive of ice-channel fillings.

Postglacial surficial features include swamp deposits, disrupted stream patterns, and a shallow weathering profile normally consisting of three zones with gradational boundaries. The drift in the region is probably Cary, and the area possibly was deglaciated more than 11,000 years ago.

Weakly metamorphosed sedimentary rocks underlie most of the Bridgewater quadrangle; the most extensive of these is the Meduxnekeag Formation of Ordovician age. The oldest unit recognized in the Meduxnekeag is composed of graywacke and slate. Conformably above this unit is the ribbon rock member consisting mostly of quartzose, argillaceous, or relatively pure limestone beds separated by layers of gray-green to green slate or shale. Enclosed within the ribbon rock member are numerous lenses of slate or slate and graywacke. Conformably overlying parts of the ribbon rock member is a green and gray slate member, which apparently thickens to the west. (Note: Recent fieldwork indicates a Middle Ordovician to Early Silurian Age for the ribbon rock member of the Meduxnekeag Formation.)

Slate and conglomerate that crop out in a small area in the northwest part of the Bridgewater quadrangle are assigned to the Nine Lake Formation of Silurian or Ordovician age. Tuff, volcanic breccia and conglomerate, rhyolite, mixed fragmental and effusive volcanic rocks, and admixed metasedimentary rocks comprise the Dunn Brook Formation, also of Silurian or Ordovician age.

Greenstone sills(?) of the Spruce Top Greenstone, considered of Ordovician (?) to Devonian (?) age, are enclosed by the Dunn Brook Formation in this region.
\end{abstract}

In the extreme northwest corner of the quadrangle, and apparently in fault contact with Ordovician and Silurian(?) or Ordovician(?) units to the southwest, are some poorly exposed undifferentiated quartzites, graywackes, siltstones, and slates of Silurian age.

The Bell Brook Formation of Silurian(?) or Devonian(?) age, or both, consists of two members. The older member is mostly conglomeratic; a younger member, which typically consists of olive-green siltstone and slate, conformably overlies the conglomerate member.

Devonian(?) cobble conglomerate occurs in one small area in the northwestern part of the quadrangle. It contains pebbles and cobbles of volcanic 
rocks which closely resemble volcanic units of Ordovician(?) to Devonian(?) age in the area.

Intrusive igneous rocks form only a small part of the bedrock of the Bridgewater quadrangle. The most extensive of the igneous rocks is the biotitic dacite-diorite dike, 5 miles long, in the central part of the quadrangle. At its north end, rhyolite and felsic fragmental rocks occur directly on strike with the dike. Garnet porphyry that contains highly altered feldspars forms two small plutons to the north and northwest of the dike. Both the plutons and the dike have thin thermally metamorphosed aureoles of tremolite-diopside hornfels wherever they have intruded limy rocks of the ribbon rock member of the Meduxnekeag Formation. The garnet porphyry plutons, especially the northernmost one of Estabrook Hill, contain inclusions of biotite-garnet hornfels formed from pelitic rocks.

A few small dikes of greenstone cut rocks of the Meduxnekeag Formation in the southeastern part of the area. Two small masses of serpentinite and a small body of metagabbro occur near a fault in the northwest part of the quadrangle.

Except for the dike and the small plutons, all the rocks in the area have been folded. More open folds predominate in areas underlain by massive competent rocks, as in the southwestern part of the quadrangle. With local exceptions, the folds in the north half and the southeast part of the quadrangle trend northeasterly. Elsewhere the folds trend northerly and to the northwest.

Vertical and steeply dipping fracture cleavage that trends northeast is common in most of the rocks. It has not developed in the brittle rocks, such as greenstone or massive conglomerate and quartzite, and is absent in the intrusive rocks which were emplaced after the cleavage formed. The intersection of cleavage and bedding, especially in slate, produces a conspicuous lineation. The most pronounced lineation, however, is that of the trend of fold axes, particularly of the larger folds. Additional lineation of local extent includes mullion structure, pencil lineation, and a peculiar lineation banding. Mineral lineation and boudinage are rare or of an incipient nature. Normally the more brittle rocks that lack cleavage are cut by widely spaced joints that generally have steep or vertical dips.

Faults are difficult to recognize in the Bridgewater quadrangle, and those that have been mapped strike either north or northeast. The movement on them is not known.

Most of the rocks in the Bridgewater quadrangle have undergone progressive regional metamorphism up to the greenschist facies; limy rocks into which small plutons and a dike have been intruded have been thermally metamorphosed locally. The plutons show no evidence of having undergone regional metamorphism, although chloritization of biotite and garnet indicates that, in part, they have been retrogressively metamorphosed.

The Bridgewater quadrangle has been covered by regional aeromagnetic and gravity surveys.

\section{INTRODUCTION}

Large potential resources of manganese in layered low-grade deposits of sedimentary origin occur in the Aroostook manganese belt of northeastern Maine (White, 1943; Miller, 1947; Pavlides, 1962). Knowledge of the stratigraphic sequence and structural framework of the rocks in this belt will be desirable if these resources of manganese are used in the future. At present, information about the 
geology of the Aroostook manganese belt consists of disconnected, generally reconnaissance-type bedrock maps of the three principal areas where manganese deposits occur (fig. 1). Systematic geologic mapping of the Bridgewater quadrangle (pl. 1) was undertaken primarily to obtain stratigraphic and structural data in terrane that partly bridges the gap in geologic mapping between the southern manganese district and the Maple and Hovey Mountains area (fig. 1).

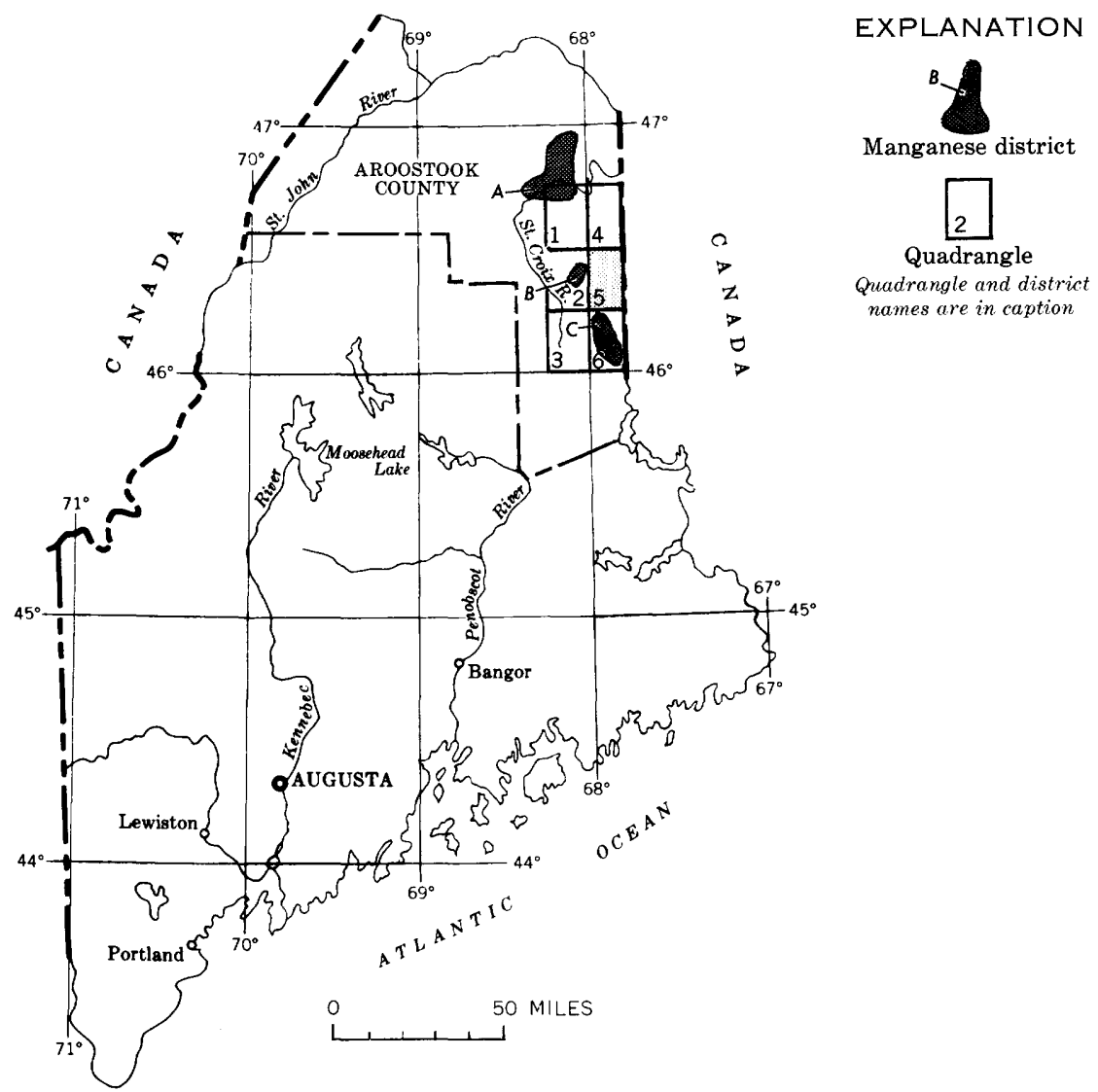

Quadrangles:
1, Presque Isle
4, Mars Hill
2, Howe Brook
5, Bridgewater
3, Smyrna Mills
6, Houlton

Manganese districts:

A, Northern manganese district

B, Maple and Hovey Mountains area

$C$, Southern manganese district

Figure 1. Index map showing the Aroostook manganese belt and the position of the Bridgewater and nearby quadrangles, Maine. 
During 1952 and 1953 the writer made a reconnaissance geologic map of a small part of the west-central part of the Bridgewater quadrangle (Pavlides, 1962, pl. 1). Fieldwork described in this report was done during the field seasons of 1956-59. The Bridgewater quadrangle is covered by a blanket of glacial drift of uneven thickness. Exposures of bedrock are locally abundant, particularly in the eastern part of the quadrangle, where there is much cleared and cultivated land; they are sparser and more widely scattered in the western, wooded part (pl. 2). Bedrock crops out where the drift is thin, as on or near the crests of hills and ridges, or where streams have incised themselves through the drift to bedrock. Typically, bedrock exposures are small (a few square feet), and many are smooth pavement surfaces that have been planed and polished by glaciation. Such pavement outcrops are of limited value because the rock is hard to break and it is therefore difficult to determine its lithology and to establish the presence and attitude of features such as bedding and cleavage. In the areas under cultivation, some bedrock exposures are ephemeral, being exposed by plowing during one season and covered by soil the next. Natural outcrops in the western, wooded part of the quadrangle are scarce, except along stream beds; construction of tote roads by means of bulldozers has provided more exposures here in recent years.

Generally, after the drainage, roads, and trails in the wooded part of the quadrangle were examined for exposures, steep slopes and crests of hills were mapped and the entire region crossed by numerous pace-and-compass traverses. Both aerial photographs and a topographic base map were used for compilation. The eastern, agricultural strip of the Bridgewater quadrangle is readily accessible, and was mapped by using aerial photographs for field compilation.

Gently rolling hills and broad undulating lowlands characterize much of the quadrangle. Relief is moderate, ranging from 100 to 300 feet in most places and attaining a maximum of nearly 500 feet in the northwest part of the quadrangle. The lowest altitude (about $340 \mathrm{ft}$ ) is in the southeast corner of the quadrangle. Nineteen Mountain, in the northwestern part of the quadrangle, is the highest feature, at an altitude slightly greater than 1,180 feet. Most of the eastern and northern parts of the quadrangle are readily accessible by a network of surfaced and unsurfaced roads. U.S. Highway 1 and the Bangor and Aroostook Railroad transect the Bridgewater quadrangle from south to north within the agricultural belt (pl. 2).

Severe winters with heavy snowfalls and freezing temperatures and short but pleasant and mild summers characterize the climate of the region. 
The economy of the area, part of the famous potato-growing region of Aroostook County, is chiefly agricultural. A striking correspondence between surficial and bedrock geology and the distribution of farmlands is apparent. In general, cultivated land is underlain by limy rocks that are covered by a thin mantle of unconsolidated glacial drift, much of which is outwash. Limy rocks make up parts of the bedrock at many places north and northeast of the Bridgewater quadrangle, and consequently the outwash deposits contain rocks of relatively local origin. Bedrock lithology, reflected in surficial deposits, apparently is of considerable importance, therefore, in determining the fertility of farm lands. Cleared land overlying noncalcareous or weakly calcareous slate is mostly used for pasture. Wood for pulp and lumber is harvested from the woodlands in the western part of the quadrangle. Deciduous trees grow mostly on ridges and slopes whereas the conifers occupy lowlands.

The few fossils found in the quadrangle were examined by several paleontologists, cited at appropriate places in this report. R. B. Neuman and A. J. Boucot, of the Geological Survey, were especially helpful in this regard. William R. Barton, Jr., Stepan Peniuk, Richard L. Mauger, and William P. Williams ably assisted the writer in the field.

\section{PALEOZOIC STRATIGRAPHY}

Sedimentary rocks ${ }^{1}$ underlie about 90 percent of the Bridgewater quadrangle. Various types of intrusive rocks or crudely layered volcanic rocks underlie the remaining 10 percent, chiefly as small disconnected masses. The sedimentary and volcanic rocks are highly folded, broken by faults, and generally transected by slaty cleavage. Obviously, well-established stratigraphic relationships between formations that have been defined through mapping are essential in working out the regional geology of the area. Many problems exist, however, in attempting to establish a stratigraphic sequence of the formations. The chief obstacle is the absence of index fossils from most of the rock units in the area. In the absence of paleontologic evidence, age relationships between some of the formations in the quadrangle based on sedimentary and structural evidence are equivocal. The possibility that unrecognized facies changes may exist between formations is a further complication.

1 Although the rocks within the Bridgewater quadrangle have been weakly metamorphosed, the original character of many is still well preserved. Metamorphic rock names or prefixes have not been used, therefore, for all rocks; the nomenclature of sedimentary and volcanic rocks is used for such rocks as graywacke and conglomerate, and tuff and trachyte, for example, even though all these rocks are in a sense, metasedimentary and metavolcanic rocks. 
The stratigraphic sequence presented herein is the one deemed most consistent within the limits of available information. Alternative stratigraphic interpretations are discussed. Additional mapping in contiguous or in geologically critical areas in the Bridgewater quadrangle wherever manmade exposures become available may necessitate a revision of some of the stratigraphic concepts here presented.

Thicknesses of the stratigraphic units in the quadrangle are not well known, chiefly because the rocks have undergone such deformation that complete or nearly complete sections free of repetition from faulting or folding are not available. Furthermore, the discontinuous nature of the bedrock exposures precludes good measurements across partial sections even where structural complications are not severe. The thicknesses given in table 1 are estimates based on measurements taken from geologic cross sections. These thickness estimates, therefore, are directly dependent upon the interpretation of the deformation pattern and the geometry of the folds used in the cross sections. Hence, the thickness values in table 1 are to be considered only as orders of magnitude.

TABLE 1.-Approximate thicknesses of stratigraphic units, Bridgewater quadrangle, Maine

\begin{tabular}{|c|c|c|c|c|}
\hline System & Formation & Member & Lenticular units & Thickness (feet) \\
\hline Devonian(?) & Cobble conglomerate & & & $120 \pm$ \\
\hline \multirow{2}{*}{$\begin{array}{l}\text { Devonian(?) or } \\
\text { Silurian(?) }\end{array}$} & \multirow{2}{*}{ Bell Brook } & Slate & & $6,000 \pm$ \\
\hline & & Conglomerate & & $0(?)$ to $5,000 \pm$ \\
\hline Silurian & Quartzite and slate & & & $4,000+$ \\
\hline $\begin{array}{l}\text { Ordovician(?) to } \\
\text { Devonian(?) }\end{array}$ & Spruce Top & & & 0 to $1,500+$ \\
\hline \multirow{2}{*}{ Ordovician or Silurian } & Dunn Brook & & & $2,000 \pm$ \\
\hline & Nine Lake & & & $18,000+$ \\
\hline \multirow{4}{*}{ Ordovician } & \multirow{4}{*}{ Međuxnekeag } & Slate & & $5,000+$ \\
\hline & & Ribbon rock & & $1,5 \mathrm{C} 0 \pm$ to $12,000+$ \\
\hline & & & $\begin{array}{l}\text { Slate and slate } \\
\text { and graywacke }\end{array}$ & 0 to $4,000 \pm$ \\
\hline & & $\begin{array}{l}\text { Slate and } \\
\text { graywacke }\end{array}$ & & $\begin{array}{l}0(?) \text { to } 5,000 \pm \\
44,600\end{array}$ \\
\hline
\end{tabular}

1 Thickness is from estimates made in the Howe Brook quadrangle (Pavlides, 1962). Only a small part of this unit is present in the Bridgewater quadrangle.

2 Total does not include the Nine Lake Formation because only a small part of it is present in the Bridgewater quadrangle.

\section{MEDUXNEKEAG FORMATION}

The Meduxnekeag Formation, as originally described (Pavlides, 1962, p. 9-12, fig: 3), was divided into three units, based on scattered exposures within a limited area in the west-central part of the Bridgewater quadrangle. The original subdivision of the Meduxne- 
keag Formation into three units is retained, but some of the units are lithologically more complex than was deduced from the exposures in the small area originally mapped.

Most of the Bridgewater quadrangle is underlain by the Meduxnekeag Formation, but two of its three members are of limited distribution. The slate and graywacke member is the oldest. It is composed chiefly of slate mixed with graywacke and is exposed in the 6road uplands of the northwest part of the quadrangle (pl. 1). The younger, ribbon rock member, is the most extensive; it covers the entire eastern part of the quadrangle and locally extends into western parts. Commonly, its limy rocks underlie broad undulating lowlands, whereas the slate or slate and graywacke lenses it encloses, because of their greater resistance to erosion, form the hills that locally stand above the lowlands.

Green slate, that occurs as a lenticular unit near the top of the ribbon rock member of the Meduxnekeag, is restricted to the westcentral part of the Bridgewater quadrangle in an area of generally subdued rolling topography.

\section{SLATE AND GRAYWACKE MEMBER}

Dark-gray slate and gray-green slate irregularly interlayered with graywacke sandstone and conglomeratic graywacke are the typical rocks that comprise the oldest member of the Meduxnekeag Formation. Locally siltstone and quartzite are also present. Some of the slate near the north-trending fault in the northwestern part of the quadrangle has been sheared and, in places, microbrecciated. Such rocks are characterized by phyllitic and schistose foliation rather than by slaty cleavage.

Because of poor exposures, there is no adequate section for determining the proportion and frequency of interlayering of the slates with each other and with the graywacke. Rocks of this unit, however, are best exposed on Chandler Ridge and along the east slope of Nineteen Mountain.

In general, graywacke occurs as layers a few inches thick enclosed in slate, or as massive beds a few feet to at least 50 feet thick, commonly separated by slate a few inches thick or many feet thick. Siltstone and quartzite locally occur as thin beds a few inches to a few feet thick enclosed by slate.

Graywacke on the ridge between Number Nine Stream and the head of Jimson Brook in T.D., R. 2., was originally mapped as a lens within the oldest unit of the Meduxnekeag Formation (Pavlides, 1962, pl. 1). Further examination of this area and the presence of comparable thicknesses of graywacke within the slate and graywacke member of the Meduxnekeag east of Nineteen Mountain and on 
Chandler Ridge indicate that such a separation is not warranted; this graywacke is therefore not distinguished as a lens in this report.

The slate and graywacke member is believed to be at least 5,000 feet thick in the northwest part of the Bridgewater quadrangle. It has not been recognized elsewhere in southern Aroostook County and it possibly is a lenticular unit that thins rapidly and wedges out completely at some relatively small distance from its outcrop area in the Bridgewater quadrangle (table 1).

Volcanic lithic fragments that occur in graywacke of the slate and graywacke member resemble some of the volcanic rocks of the Dunn Brook Formation. In addition, a chip of antigoritic serpentinite, similar to that of the small masses of serpentinite within the northwest part of the Bridgewater quadrangle is present in one thin section of graywacke from the slate and graywacke member. These clasts suggest, but do not prove, derivation from the Dunn Brook and serpentinite of the region. If the clasts are indeed derived from this source, then the slate and graywacke member of the Meduxnekeag Formation is younger than the Dunn Brook Formation of Silurian(?) or Ordovician(?) age (see below) as well as the serpentinite. It might also be younger, therefore, than the ribbon rock member (Middle Ordovician age) of the Meduxnekeag Formation, beneath which it is placed stratigraphically in this report. Another source for the volcanic clasts in graywacke within the slate and graywacke member of the Meduxnekeag Formation is the volcanic rocks of Early Ordovician age about 30 miles to the southwest (Neuman, 1964), although no serpentinite has been reported from this area (Ekren, 1961). In general, however, evidence as to top facing direction of sedimentary features, although sparse, supports an age older than the ribbon rock member and this evidence is accepted in this report for dating the graywacke and slate member as of Middle Ordovician age or older.

\section{SLATE}

Dark-gray to nearly black slate, commonly of a dark gray-blue shade, is the most abundant variety of slate found in the slate and graywacke member. Much of this slate is finely laminated but it also occurs as unlaminated slate, and, in a few places, as massive and uncleaved argillite. Fine-grained pyrite is normally the only mineral megascopically recognizable where present. In weathered outcrops such pyritic slate is commonly stained brown.

The dark-gray to nearly black slate contains a micaceous and chloritic groundmass which encloses clastic grains. The mica is mostly fine-grained sericite (the term is here used in the petrographic sense of finely divided flakes of white mica), but fine-grained flakes of muscovite are also present. Colorless or pale-green, weakly pleo- 
chroic chlorite of low interference colors is typical of this slate. It occurs as small subequant flakes or as an irregular fine-grained constituent intimately mixed with sericite and distinct flakes of muscovite. The chloritic and micaceous groundmass forms a mat in which silt and finer sized fragments of quartz and sparser grains of feldspar, zircon, sphene, and pyrite or other opaque grains are embedded. In some places, finely divided carbonaceous matter is also present and may locally contribute to the dark color of the slate.

Dark-gray or nearly black slate also grades to graywacke. Such gradational slate commonly has a slightly gritty feel and very fine grained clastic grains are generally visible with the aid of a hand lens. In thin section this rock shows a typical graywacke texture, insofar as it is composed of unsorted clastic grains embedded in a micaceous and chloritic paste. The clastic grains are commonly quartz with lesser amounts of feldspar and chert.

Gray-green slate within the slate and graywacke member also occurs as finely laminated to unlaminated rock. Similarly colored slate, however, occurs in many other formations in the region and an individual exposure of such slate is indistinguishable as to its stratigraphic position, except insofar as is suggested by its field relationship to the surrounding rocks. Gray-green slate is similar to the dark-gray to black slate described above, except that carbonaceous matter is absent and gradation to graywacke has not been observed.

\section{GRAYWACKE}

Graywacke is used in this report as defined by Gilbert (Williams, Turner, and Gilbert, 1958, p. 289-294). It is an impure sandstone containing 10 percent or more of argillaceous matrix which encloses unsorted or poorly sorted grains of stable (quartz, chert, quartzite) and unstable (feldspar, rock fragments) constituents, or both. The ratio of stable constituents, feldspar, and unstable rock fragments is used as the basis for subdividing graywacke into different compositional types (fig. 2).

Most of the graywacke in the slate and graywacke member of the Meduxnekeag Formation occurs as a dark-gray rock that may contain vitreous quartz grains, rock fragments (among which slate is the most readily recognized), and feldspar, set in an argillaceous matrix. Any or all of the above grains may be present in different amounts in any particular rock. Commonly, the rock weathers to a rust color or is speckled with rust-colored dots or small patches, formed from the weathering of ferruginous carbonate or sulfide grains, or from both. Most of the graywacke layers are massive but a few show a subtle graded bedding although distinct graded bedding is not common. Crossbedding normally is not megascopically visible, but thin section examination indicates that it is present 


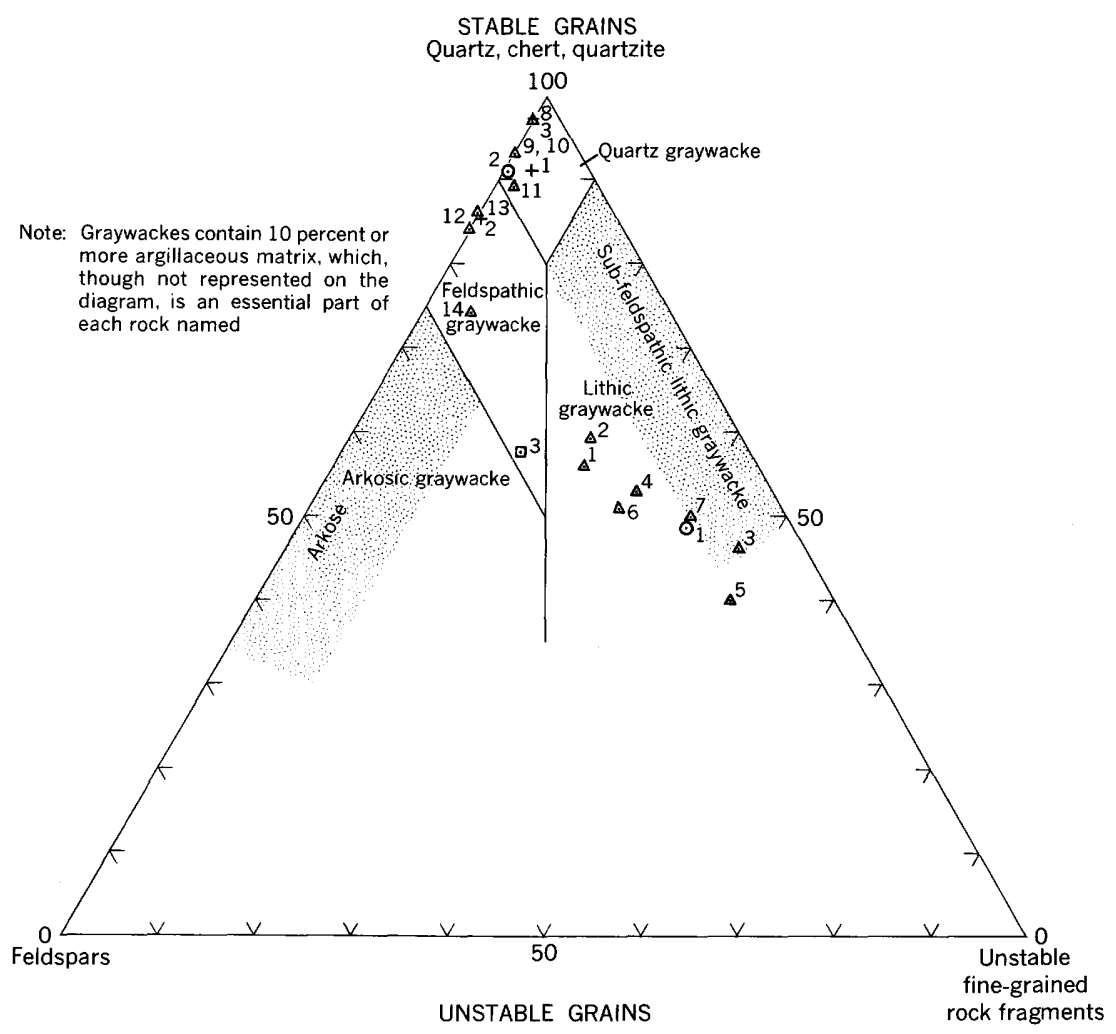

Figure 2.-Classification of graywacke (after Williams, Turner, and Gilbert, 1958). Graywackes from the Bridgewater quadrangle are plotted as follows: $\triangle$, slate and graywacke member of the Meduxnekeag Formation; $\odot$, conglomerate member of the Bell Brook Formation; $\square$, slate member of the Bell Brook Formation; and + , quartzite and slate unit. Numbers correspond to specimens in tables 2,3 , and 4 .

as a small-scale feature in some of the finer grained rocks. Typically, the foreset beds of such small-scale crossbedding are outlined by heavy mineral grains along the layering. At a few places, graywacke beds underlain by slate layers contain pebble-sized slate chips similar to the slate beneath the graywacke. Some of the slate chips are bent or slightly curled.

Modal analyses of graywacke from the lower member of the Meduxnekeag Formation are given in table 2. Individual grains of muscovite and chlorite larger than silt size $(0.06 \mathrm{~mm})$ were counted separately from the matrix mica and chlorite. All grains less than silt size were counted as matrix. Some detrital quartz, therefore, was included with the micaceous paste as matrix. In the lithic graywacke samples of table 2, however, such detrital quartz is a small fraction of the matrix constituents, which are mostly fine chlorite and sericite. 
TABLE 2.-Modal analyses of graywacke from the slate and graywacke member of the Meduxnekeag Formation and the proportion of quartz, feldspar, and rock fragments calculated to $10 \mathrm{C}$ percent

\begin{tabular}{|c|c|c|c|c|c|c|c|c|c|c|c|c|c|c|}
\hline \multirow[b]{2}{*}{ Sample.. } & \multicolumn{7}{|c|}{ Lithic graywacke } & \multicolumn{4}{|c|}{ Quartz graywacke } & \multicolumn{3}{|c|}{ Feldspathic graywacke } \\
\hline & 1 & 2 & 3 & 4 & 5 & 6 & 7 & 8 & 9 & 10 & 111 & 12 & 131 & 14 \\
\hline Specimen ...... & $\mathrm{P}-56-2$ & P-56-11 & $\mathrm{P}-56-12$ & P-56-62 & P-56-114 & $\mathrm{P}-56-129$ & $\mathrm{P}-56-134$ & P-50-12 & $\mathrm{P}-52-8$ & $\mathrm{P}-57-60$ & P-56-141 & P-56-135 & $\mathrm{P}-57-62$ & P-57-63 \\
\hline Point counts_.. & 1350 & 1385 & 1392 & 1343 & 1505 & 1000 & 530 & 1103 & 1342 & 2051 & 508 & 1051 & 717 & 1747 \\
\hline $\begin{array}{l}\text { Quartz } \\
\text { Feldspar } \\
\text { Rock fragments } \\
\text { Chlorite } \\
\text { Muscovite- } \\
\text { Matrix } \\
\text { Carbonate } \\
\text { Other }\end{array}$ & $\begin{array}{r}17.3 \\
5.6 \\
8.3 \\
4.2 \\
.3 \\
62.2 \\
0 \\
1.9\end{array}$ & $\begin{array}{r}21.9 \\
6.1 \\
9.3 \\
.6 \\
1.2 \\
57.6 \\
3.0 \\
.1\end{array}$ & $\begin{array}{r}18.7 \\
2.7 \\
18.9 \\
.1 \\
.4 \\
56.3 \\
2.9 \\
.1\end{array}$ & $\begin{array}{r}24.6 \\
6.4 \\
15.7 \\
.9 \\
.7 \\
40.0 \\
11.2 \\
.5\end{array}$ & $\begin{array}{r}20.4 \\
5.6 \\
25.4 \\
.1 \\
.3 \\
30.1 \\
17.9 \\
.1\end{array}$ & $\begin{array}{r}22.9 \\
7.7 \\
14.3 \\
1.0 \\
.1 \\
53.5 \\
.2 \\
.3\end{array}$ & $\begin{array}{r}25.5 \\
5.1 \\
20.0 \\
1.1 \\
.9 \\
33.6 \\
13.8 \\
0\end{array}$ & $\begin{array}{r}52.8 \\
1.6 \\
0 \\
.3 \\
1.7 \\
42.7 \\
0 \quad .9 \\
\quad .9\end{array}$ & $\begin{array}{r}47.2 \\
3.5 \\
0 \\
.7 \\
2.5 \\
44.8 \\
0 \\
1.2\end{array}$ & $\begin{array}{r}20.6 \\
1.5 \\
0 \\
3.1 \\
1.3 \\
58.8 \\
13.8 \\
.9\end{array}$ & $\begin{array}{r}8.1 \\
.8 \\
.2 \\
3.0 \\
3.0 \\
32.9 \\
49.8 \\
2.4\end{array}$ & $\begin{array}{r}14.5 \\
2.8 \\
0 \\
2.2 \\
.7 \\
69.5 \\
9.4 \\
.9\end{array}$ & $\begin{array}{r}25.0 \\
4.0 \\
0 \\
.8 \\
.4 \\
24.1 \\
44.5 \\
1.1\end{array}$ & $\begin{array}{r}21.4 \\
6.1 \\
1.6 \\
1.3 \\
.3 \\
69.0 \\
0 \\
.3\end{array}$ \\
\hline Total. & 99.8 & 99.8 & 100.1 & 100.0 & 99.9 & 100.0 & 100.0 & 100.0 & 99.9 & 100.0 & 100.2 & 100.0 & 99.9 & 100.0 \\
\hline \multicolumn{15}{|c|}{ Ternary composition } \\
\hline $\begin{array}{l}\text { Quartz } \\
\text { Feldspar } \\
\text { Rock fragments. }\end{array}$ & $\begin{array}{l}56 \\
18 \\
26\end{array}$ & $\begin{array}{l}59 \\
16 \\
25\end{array}$ & $\begin{array}{r}46 \\
7 \\
47\end{array}$ & $\begin{array}{l}53 \\
14 \\
33\end{array}$ & $\begin{array}{l}40 \\
11 \\
49\end{array}$ & $\begin{array}{l}51 \\
17 \\
32\end{array}$ & $\begin{array}{l}50 \\
10 \\
40\end{array}$ & $\begin{array}{r}97 \\
3 \\
0\end{array}$ & $\begin{array}{r}93 \\
7 \\
0\end{array}$ & $\begin{array}{r}93 \\
7 \\
0\end{array}$ & $\begin{array}{r}89 \\
9 \\
2\end{array}$ & $\begin{array}{r}84 \\
16 \\
0\end{array}$ & $\begin{array}{r}86 \\
14 \\
0\end{array}$ & $\begin{array}{r}74 \\
21 \\
5\end{array}$ \\
\hline Total_. & 100 & 100 & 100 & 100 & 100 & 100 & 100 & 100 & 100 & 100 & 100 & 100 & 100 & 100 \\
\hline
\end{tabular}

1 The high carbonate content makes this rock a calcareous graywacke; because of the herein used.

argillaceous content of the matrix, however, it is still included in the classification

\section{Location of specimens}

1. P-56-2, about 1.04 miles S. $83^{\circ} 00^{\prime} \mathrm{W}$. from the northwest corner of Cox Patent. 2. P-56-11, from the North Branch Whitney Brook about 1.11 miles S. $16^{\circ} 00^{\prime} \mathbf{E}$. from the northwest corner of Cox Patent.

3. P-56-12, from the North Branch Whitney Brook about 1.45 miles S. $20^{\circ} 00^{\prime}$ E. rom the northwest corner of Cox Patent.

of Cox Patent.

5. P-56-114, about 2.22 miles S. $51^{\circ} 00^{\prime}$ W. from the northwest corner of Cox Patent.

7. P-50-129, about 0.91 mile N. $25^{\circ} 00^{\prime}$ W. from the northwest corner of Cox Patent.

corner of Cox Patent.

8. P-50-12, about 3.73 miles S. $52^{\circ} 00^{\prime}$ W. from the northwest corner of Cox Patent. 9. P-52-8, from Number Nine Stream about 3.38 miles S. $57^{\circ} 00^{\prime}$ W. from the north10. P-57-60 about 0.79 mile, S. $32^{\circ} 00^{\prime}$ E. from the northwest corner of Cox Patent. 11. P-56-141, about 0.54 mile, N. $64^{\circ} 00^{\prime}$ E. from the northwest corner of Cox Patent 12. P-56-135, from Chandler Ridge about 2.06 miles S. $56^{\circ} 30^{\prime}$ W. from the southeas

13. P-57-62, about 0.25 mile, N. $33^{\circ} 30^{\prime}$ E. from the southeast corner of Cox Patent. 14. P-57-63, about 1.16 miles, S. $50^{\circ} 30^{\prime}$ E. from the northwest corner of Cox Patent. 
Lithic graywacke.-Most of the graywacke from the oldest member of the Meduxnekeag Formation is lithic graywacke (fig. $3 A$ ). Petrographic examination, however, indicates considerable differences among such rocks. For example, chert (included with quartz in modal analysis) is present in samples 1 and 2 (table 2) but absent in the other 5 samples of lithic graywacke. Carbonate is abundant in samples 4, 5, and 7 and absent or minor in the other rocks. There is also a wide range in composition among the essential constituents of these rocks; the quartz content ranges from approximately 17 to 25 percent, the feldspar content from nearly 3 to 8 percent, and the rock-fragment content from about 8 to 25 percent. Matrix is present in amounts ranging from about 30 to 62 percent.

There is also a wide range in content and variety of rock fragments in the lithic graywackes. In some, sedimentary rock chips are the most common lithic fragments, and in others, volcanic rock fragments are the principal lithic constituents. In a few rocks, chips of sedimentary and volcanic rocks are present in about equal amounts. The volcanic rock chips are almost entirely felsic, being mostly trachyte, tuff, and rhyolite.

Strained and unstrained quartz are both common in lithic graywacke and occur together in the same rock. In some rocks the quartz is rutilated. Plagioclase and potassium feldspar are also both present in lithic graywacke, but plagioclase is the more abundant. Both feldspars have sericitic alteration but plagioclase is commonly less altered or nearly fresh in appearance.

A total of 17 lithic graywacke samples (including those of table 2) were studied petrographically. A textural feature common to them, as well as to all graywacke of the region, is the poorly sorted character of the grains. In general, the average grain size of lithic graywacke is sand ( 0.06 to $2.0 \mathrm{~mm}$ ), but all gradations from fine to very coarse sand occur in different graywacke layers. The over-all range in grain size is normally from silt (less than $0.06 \mathrm{~mm}$ ) to coarse sand (1 to $2 \mathrm{~mm}$ ), but some grains, particularly lithic fragments, are of granule ( 2 to $4 \mathrm{~mm}$ ) and pebble (4 to $64 \mathrm{~mm}$ ) gravel sizes, although the coarsest pebble (slate) measured in such rocks is about $30 \mathrm{~mm}$ long. Inasmuch as granules and pebbles generally form a small proportion of these rocks, the rocks properly are graywackes (sandstone size) rather than conglomerates. The coarser grained rocks, however, also contain the larger sized grains, which normally are lithic fragments and principally slate chips.

Quartz graywacke.-Although less abundant than lithic graywacke, quartz graywacke is common in the slate and graywacke member. Graywacke exposed on the ridge between the headwaters of Jimson Brook and Number Nine Stream in the northwest part of 


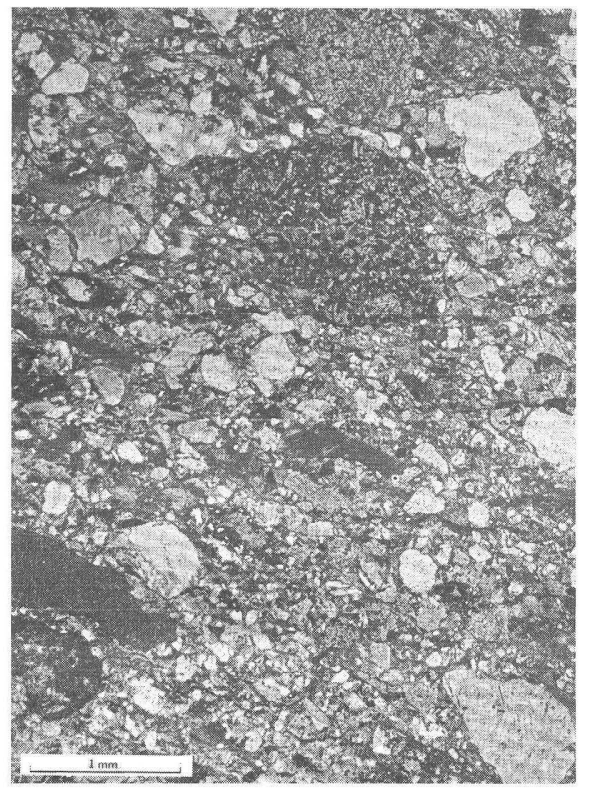

A

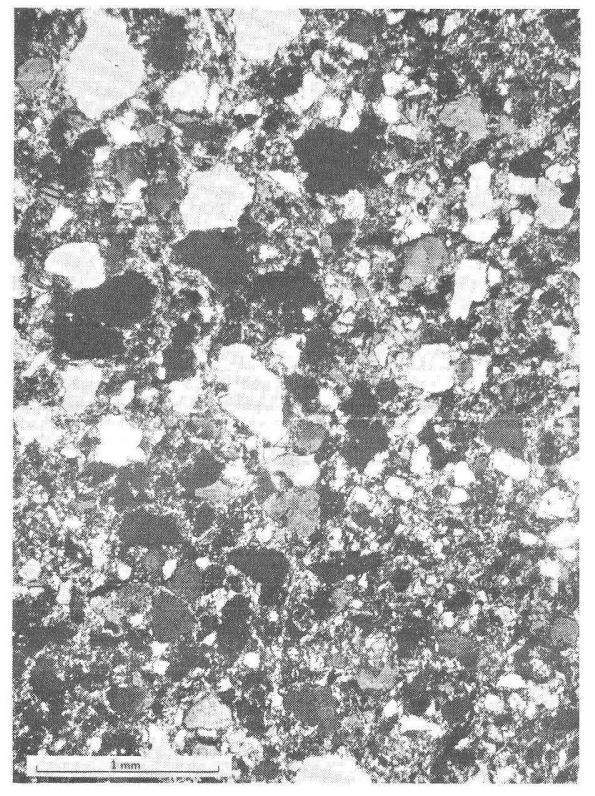

$B$

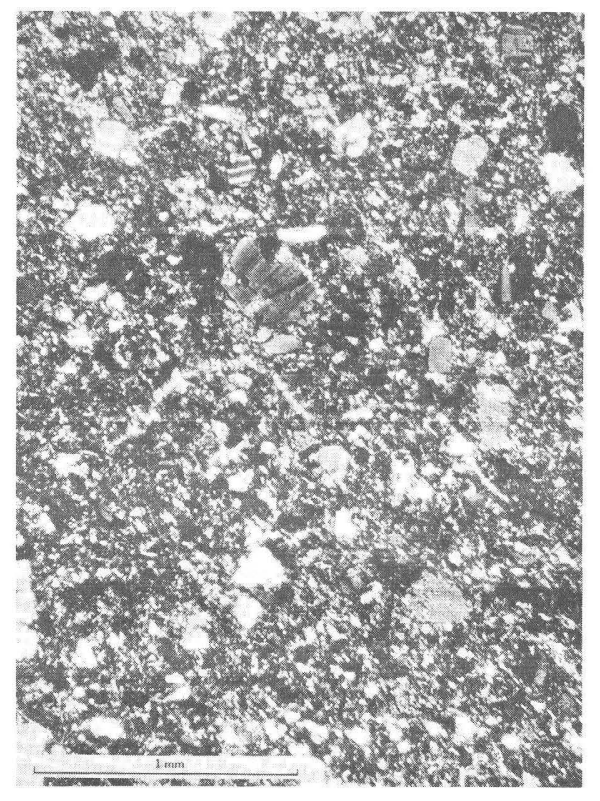

C

FIGURE 3.-Photomicrographs of graywackes from the slate and graywacke member of the Meduxnekeag Formation. A, Lithic graywacke (No. 1 of table 2), plane-polarized light. B, Quartz graywacke (No. 8 of table 2), crossed nicols. C, Feldspathic graywacke (No. 14 of table 2), crossed nicols. 
T.D., R. 2. (pl. 1) is a typical quartz graywacke (fig. $3 B$ ). It is poorly sorted and contains subrounded to angular grains that are mostly quartz (see No. 8, table 2), much of which appears rutilated. Plagioclase is present but sparse, and rock fragments are absent. The matrix consists of a paste of fine sericite and chlorite. Leucoxene-coated sphene and zircon are minor accessory constituents.

Quartz graywacke has a rather wide range in bulk composition, however, as illustrated in part by the modal analyses of table 2 (Nos. 8-11), but is distinct from lithic graywacke (fig. 2). Besides the wide range in composition of the essential constituents, matrix, quartz, and feldspar, there is also a wide range in carbonate content. In some rocks, carbonate is absent, and in others it is present in different amounts making up almost 50 percent of the rock (see No. 11, table 2). Tourmaline, ilmenite, leucoxene-coated sphene, and zircon are detrital accessory minerals. Pyrite is common; its cubic habit and the fact that it appears to replace quartz in some rocks, indicate that it is probably authigenic.

Feldspathic graywacke.-These rocks are similar in hand specimen to quartz graywacke, but can be distinguished in thin section (fig. $3 \mathrm{C}$ ). Generally, a modal analysis is needed to differentiate between quartz and feldspathic graywacke. Modal analyses of three feldspathic graywacke samples from the lower Meduxnekeag are listed in table 2, and the analyses are also plotted on figure 2. Feldspathic graywacke also has a rather wide range in bulk composition including marked differences in carbonate content. The carbonate is ankeritic and commonly iron stained. Feldspathic graywacke is distinguished from lithic graywacke by the virtual absence of rock fragments and from the quartz graywacke by a greater feldspar to quartz ratio. Rock fragments may or may not be present in feldspathic graywacke, but where present they are commonly of felsic rocks.

\section{RIBBON ROCK MEMBER}

The ribbon rock member of the Meduxnekeag Formation described elsewhere (Pavlides, 1962, p. 11-12) is the most widespread unit in the Bridgewater quadrangle. Although it consists of a wide variety of sedimentary rocks, it is chiefly buff-weathered, gray to blue limestone irregularly interlayered with gray to gray-green slate. On weathered outcrops and in outcrops in stream beds, the limestone layers are commonly more deeply eroded than the slate interbeds. This differential erosion imparts a pronounced ribbed appearance to such outcrops; hence they have been variously described as "ribbon rock" and "ribbon limestone." Calcite, locally derived from the limy rocks during deformation, commonly is present in irregular veinlets or sometimes along cleavage. The slate interbeds generally 
have few, if any, of these calcite veinlets because the slate was more plastic during deformation (slate intruded cleavage in limestone layers at several places) and less prone to open fracturing than the more brittle limestone layers. Thin (one-half inch or less) white, nearly pure calcite layers are also locally present as interbeds of gray-blue ribbon limestone and are conformably folded with the limestone. These layers may have been predeformation calcite fillings along bedding joints which were subsequently folded conformably with the enclosing limestone. Thin, intricately contorted, nearly pure calcite veinlets that crosscut bedding are also present.

The ribbon rock member has the greatest thickness of any unit mapped in the Bridgewater quadrangle. (See table 1.) It is estimated to be more than 12,000 feet thick in most of the eastern part of the quadrangle. In the west-central part of the area (pl. 2), however, it is only about 1,500 feet thick. This difference in thickness from east to west may be due to original westward stratigraphic thinning, inasmuch as the more westward rocks of the same age are of different kinds (Pavlides and others, 1964, p. C31-C32).

Ribbon rock can be classed as thin bedded or thick bedded, depending upon the thickness of individual layers of limestone and slate. Thus, thin-bedded ribbon rock is composed of limy layers 0.5 to 1.0 inch thick which are commonly separated by slate layers 0.5 inch thick or less. Thick-bedded ribbon rock consists of limy layers 0.5 foot thick or more, separated by slate layers several inches or more thick. There are all gradations of ribbon rock between thick-bedded and thin-bedded varieties, and such gradational types make up the bulk of this lithology.

In addition to its thin- and thick-bedded features, ribbon rock is also characterized by two distinctive compositional varieties, namely, quartzose limestone and a variety that is megascopically free of quartz.

In the northwest part of Littleton Township, in the south-central part of the Bridgewater quadrangle (pl. 1), normal ribbon rock lithology changes along strike into a facies consisting mostly of dark-gray slate which has sparser interbeds of gray-blue to gray quartzose and relatively quartz-free limy rock. The slate in this facies is dark gray and noncalcareous, and commonly has a fine lamination. Thin silty or quartzitic layers 1 to 2 inches thick are also present locally.

\section{RIBBON ROCE WITH QUARTZOSE LIMESTONE}

Quartzose limestone typically has silty laminae which stand in higher relief on weathered surfaces than the carbonate matrix. Such fine-grained quartzose layers commonly impart a fine lamination to limestone beds; in many rocks a very complex crossbedding is evi- 
dent that normally is not usable in determining tops of beds. Silty quartzose laminae in many of the limestone beds generally are also intricately contorted between even-layered beds of slate and resemble small-scale intraformational folds or curled bedding (fig. 4) that is similar to convolute bedding described by Kuenen (1953a, p. 1056). Some geologists have found convolute bedding useful in determining the top-facing direction of beds, and also in roughly estimating the current direction (Haaf, 1956; Kuenen, 1953b). Although a thorough study of convolute bedding in ribbon rock of the Meduxnekeag Formation has not been made, wherever tested convolute layering was found to be consistent with the top-facing direction of beds determined by associated features, such as graded bedding. The use of convolute bedding to estimate current direction is founded on the assumption that convolute bedding is indeed a current phenomenon, such as plastically deformed ripple marks (Kuenen, 1953b, p. 14-24). This interpretation has not been conclusively documented as being the only way in which convolute bedding may form. Migliorini (1950; in Haaf, 1956, p. 193), for example, proposed an equally plausible hypothesis of convolution formation by dewatering of a hydroplastic sediment during compaction. Rich (1950) believes such intrastratal contortions form in unconsolidated, water-saturated silty layers (quicksand) and that they act as glide zones along which the overlying sediments may slide down a slope. In this process the bedding within the water-saturated silty glide zone is contorted. In view of the uncertainty as to the origin of convolute bedding, no attempt was made to interpret current direction from it.

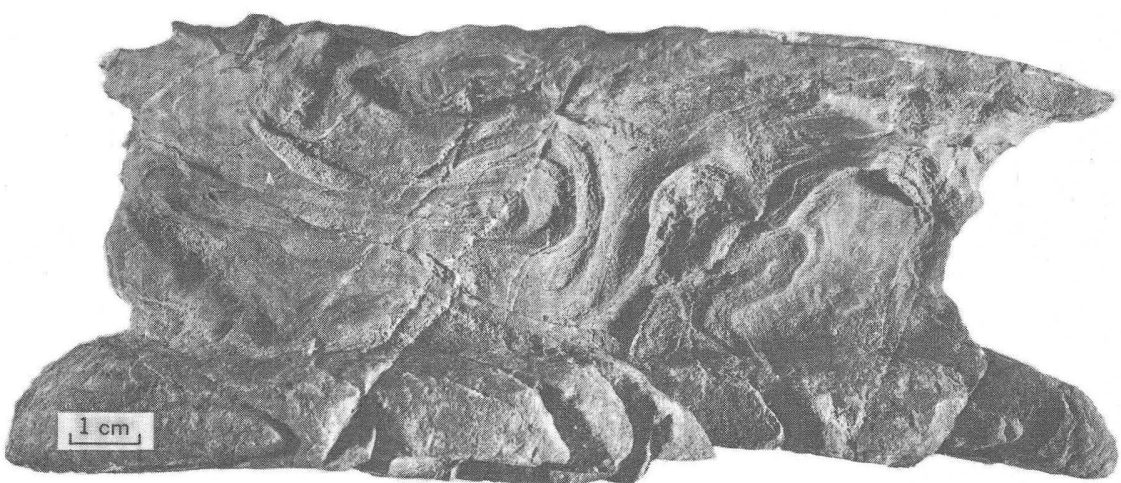

Figure 4.-Convolute layering in ribbon limestone of the Meduxnekeag Formation. Silty quartzose laminae enclosed in limestone are intricately contorted. The slate layers that enclose the contorted limestone are undisturbed. Topfacing direction not known. Specimen collected from Number Nine Stream about $11,500 \mathrm{ft}, \mathrm{S} .69^{\circ} \mathrm{W}$. from the southwest corner of Cox Patent. 
Graded bedding is also present in some of the quartzose limestone layers. It is characterized by a gradation from quartzose limestone at the base of a bed that grades upward into slate, which in turn has a sharp contact with overlying quartzose limestone. Such graded bedding is not present as an extensive cyclical sequence at any one place. It commonly occurs in one or a few layers which are interbedded with, or enclosed by, nongraded quartzose limestone beds, and is thus a subordinate feature. In general, graded bedding is not common and is not readily detectable in ribbon rock.

Very fine grained muscovite and pyrite are also present as megascopic constituents of quartzose ribbon rock. Generally, muscovite flakes are alined along bedding. Pyrite, where present, normally occurs as finely disseminated grains which are commonly cubic.

Quartzose ribbon rock consists mostly of fine-grained angular quartz grains set in a carbonate matrix (fig. 5A) which may be calcitic or ankeritic. ${ }^{2}$ In addition to quartz, some fine-grained angular to subrounded fragments of slate, felsic volcanic rocks, and chert are present and sorting is poor (fig. 5B). Plagioclase is also present but is not abundant. Additional minor constituents commonly are leucoxene-coated sphene, pyrite, zircon, and epidote. Muscovite, though minor, is ubiquitous and occurs as flakes along bedding planes (fig. $5 \mathrm{C}$ ). The fact that in some rocks the coarsest carbonate grains occur in layers containing the coarsest detrital quartz grains suggests that such grains were transported and deposited together and that the carbonate also was detrital.

\section{RIBBON ROCK WITH LIMESTONE ALMOST FREE OF QUARTZ}

Relatively quartz-free limestone in ribbon rock occurs as massive and dense gray-blue layers that have slate interbeds; such ribbon rock is commonly thick-bedded rather than thin-bedded. The limy beds may be calcareous argillite, argillaceous limestone, or limestone. Some of the more dense limy rocks break with a subconchoidal fracture. Limestone beds that appear megascopically as relatively quartz-free rocks commonly contain some detrital quartz visible only under the petrographic microscope. Such rocks consist of very fine grained carbonate that contains sparse quartz grains, flakes of sericite, and fine opaque grains.

\section{SLATE}

The slate interbeds or partings in ribbon rock generally are gray, gray green, or green and are massive or finely laminated; they may or may not be calcareous. Generally, gray slate is calcareous, con-

2 The term "ankeritic carbonate" as used in this report refers to carbonate which has indices of refraction greater than canada balsam and, when weathered, imparts a buff to brown coloring to the rocks. X-ray diffraction analyses of bulk rock samples also indicate that the carbonate has a dolomite structure. Hence, ankeritic carbonate has a compositional range between ferruginous dolomite and ankerite. 


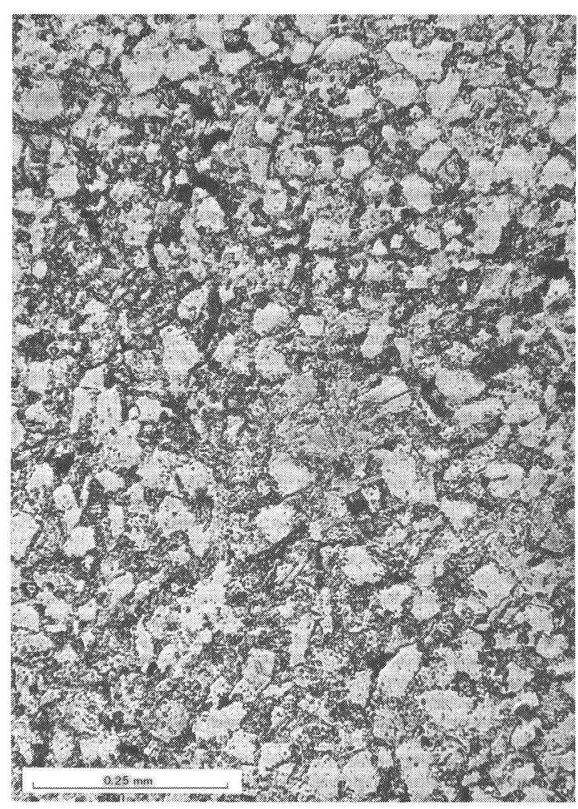

$A$

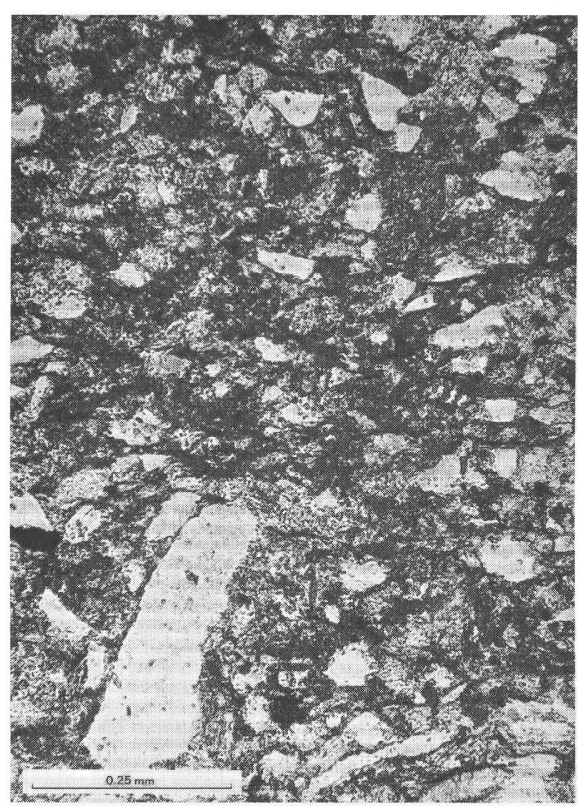

$B$

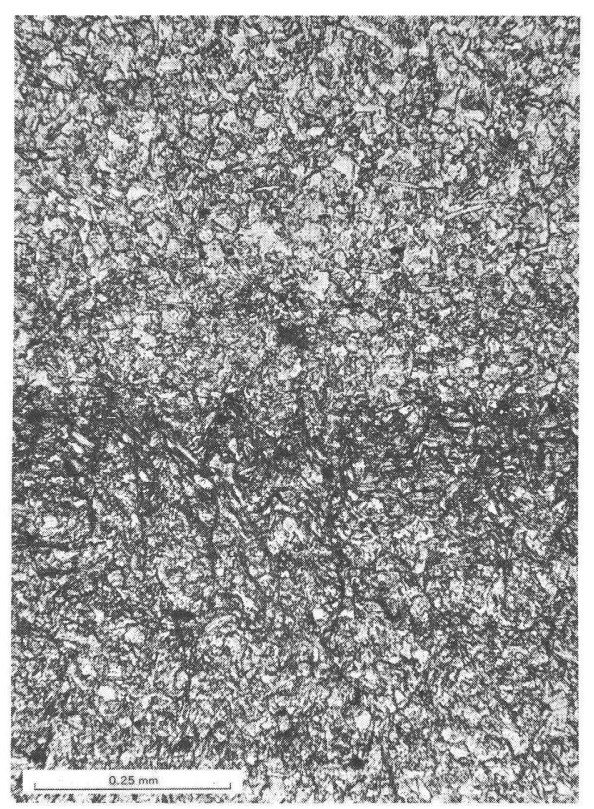

$C$

FigURE 5.-Photomicrographs of impure carbonate rocks from the ribbon rock member of the Meduxnekeag Formation. A, Quartzose limestone; consists chiefly of angular quartz grains in a carbonate matrix. Not discernible in the photograph but also present are feldspar and some fine sericite and chlorite. The opaque grains are leucoxene-coated sphene and magnetite. B, Poorly sorted quartzose limestone; consists chiefly of angular quartz grains in a carbonate matrix. Also present in this thin section but not discernible in the photograph are rock fragments (slate, tuff(?), and chert), feldspar (rare), white mica, and leucoxene-coated sphene and epidote. $C$, Fine-grained quartzose limestone that has a lamina of slate cut by fracture cleavage which does not cut the enclosing quartzose limestone. Fine flakes of mica in the quartzose limestone and in the slate are subparallel to bedding rather than to cleavage. 
tains calcitic carbonate, and is chiefly distinguished by its effervescence when treated with cold, dilute hydrochloric acid. Noncalcareous slate may or may not contain carbonate. Where carbonate is present it is probably ankeritic, because it is commonly iron stained, and where unweathered, it does not effervesce when treated with dilute hydrochloric acid.

These slates consist of a matrix composed of fine-grained white mica, chlorite, carbonate, and fine-grained quartz grains. Commonly the chlorite and mica flakes lie in the plane of the bedding. Palegreen or colorless chlorite and white mica both occur as fine flakes in the matrix and as larger porphyroblastic flakes, which are believed to have formed through metamorphism. Feldspar is present in some slate; opaque grains are common. In some slate, the fine lamination results from the presence of quartzose silty layers which may range from a quartz graywacke (consisting of silt-size detrital quartz grains embedded in a micaceous paste) to nearly pure quartzite.

\section{LENTICULAR UNITS}

Numerous, apparently lenticular units, are enclosed by the ribbon rock member of the Meduxnekeag Formation and locally underlie considerable areas of the quadrangle. (See pl. 1.) The stratigraphic position of these lenses within this member is not known, but they seem to lie at several levels; the order in which they are discussed below may not be chronological.

Some lenticular units are as much as 4,000 feet thick; they may wedge out completely or grade into enclosing ribbon rock over short distances. (See table 1.)

Graywacke and slate lenses.-Graywacke interlayered with slate crops out in two small areas near Harvey in the northwestern part of Monticello Township (pl. 1). Lithologically these rocks are similar to slate and graywacke of the slate and graywacke member of the Meduxnekeag Formation. The slate is generally dark gray to dark green and noncalcareous; the graywacke ranges in composition between lithic and feldspathic graywacke.

In addition to the graywacke and slate areas near Harvey, slate and graywacke also occur locally as thin strata interlayered with ribbon rock. Such graywacke-slate beds are present in ribbon rock along South Brook (formerly called South Branch Meduxnekeag River) west of the dacite-diorite dike and along the North Branch Meduxnekeag River west of its junction with Number Nine Stream (pl. 1). Compositionally, the graywacke of such layers includes both lithic and feldspathic types.

Graywacke mixed with slate, and locally containing quartzose ribbon rock, is also present as an ill-defined lens in the west-central part of Monticello Township. The graywacke is in massive mica- 
ceous gray beds about 1 to 2 feet thick; it ranges in composition from quartz graywacke to lithic graywacke.

Slate lenses.-Large areas of the eastern part of the Bridgewater quadrangle are underlain by slate. Generally the slate occurs in masses surrounded by ribbon rock that appear to represent several lenticular horizons of slate within ribbon rock. At some places the ribbon rock and slate lenses appear to have sharp contacts, but contacts are mostly gradational, particularly those of the slate lenses in the east-central part of the quadrangle.

Composition of the slate lenses within ribbon rock varies considerably. Generally, the slate is gray to gray-green and may or may not be calcareous. The slate lens along and near the Canadian border in the northeast part of the quadrangle locally is dark gray and finely laminated. The lenses in the northeastern and east-central part of the quadrangle have sparse gritty layers of quartzitic graywacke.

South of about the latitude of Britton Road, graywacke layers become more abundant in the slate lenses in the eastern part of the quadrangle. The graywacke content increases so rapidly to the south that actually the lithology of the slate lens in the southeastern part of the quadrangle, which is bounded by a fault on its northwest side, changes southward along strike from slate with sparse graywacke layers to a sequence composed of nearly equal amounts of slate and graywacke. This lithology extends as such from Lowell Hill to the southwest limit of the lens near Ross School (pl. 1). The slate in this part of the lens is gray green or green and is not calcareous; the sandy beds that are commonly interlayered with it generally range in composition between quartz and feldspathic graywacke.

\section{SLATE MEMBER}

Gray, gray-green, and green slate, estimated to be about 5,000 feet thick (table 1), occurs west of the thin ribbon rock member of the Meduxnekeag in the western part of T.D., R. 2 (pl. 1). To the east the unit may wedge out rapidly. (See section $B-B^{\prime}$, pl. 1.) It is normally not calcareous, although locally limy layers, some of which resemble limestone beds of the ribbon rock member of the Meduxnekeag, are present. The slate may be massive or finely laminated. Megascopically it is not distinguishable from the gray and green slate of Silurian age of the Maple Mountain Formation (Pavildes, 1964, p. B5) of the Hovey Group (formerly the upper part of the Hovey Formation (Pavlides, 1962, p. 16)) to the west in the Howe Brook quadrangle. It is herein tentatively included as an upper member of the Meduxnekeag Formation on the basis of its field relationships; it is structurally conformable with the ribbon rock 
member to the east which in turn structurally and stratigraphically overlies the slate and graywacke member. Additional mapping in the Howe Brook quadrangle may more closely establish the stratigraphic position and age assignment of this slate unit.

The Ordovician age ${ }^{3}$ assigned the Meduxnekeag Formation is based on the dating of the ribbon rock member and the supposition that the slate member above and the slate and graywacke member below are a conformable sequence of virtually similar age.

The ribbon rock member of the Meduxnekeag Formation is believed to be of Middle or Late Ordovician age. The fossils that date this unit occur, however, outside of the Bridgewater quadrangle. A late Middle Ordovician age for these rocks was established by the discovery of graptolites about 36 miles northwest of Bridgewater near Colby (Pavlides, Neuman, and Berry, 1961, p. 65-66). The graptolites recognized by W. B. N. Berry from this locality (USGS, loc. 4132-CO) are: Amplexograptus sp.; A. cf. A. perexcavatus (Lapworth); Climacograptus ef. C. typicatis mut. postems Reudemann; Diplograptus (?) spp. (two distinct kinds of this form are represented; one is long and slender, the other is shorter and wider); Orthograptus aff. O. truncatus (Lapworth); O. truncatus cf. var. intermedius (Elles and Wood); other orthograptids of the O. truncatus type. These fossils, although poorly preserved, nonetheless are considered as a characteristic assemblage of Trenton age. At Houlton, about 21 miles south of Bridgewater, a few fossils were found in 1961 in small limy lenses in ribbon rock, including a leptellid and Zygospira and date the enclosing rock as Middle or Upper Ordovician in age (R. B. Neuman, written commun., 1961; A. J. Boucot, written commun., 1964). The Matapedia Group of Gaspé, Quebec, with which the ribbon rock member of the Meduxnekeag Formation is believed to be coeval, in part (Pavlides, Neuman, and Berry, 1961, p. 66-67), is dated as Late Ordovician by Beland (1958, p. 3-4).

Within the Bridgewater quadrangle itself, however, fossils were found in the ribbon rock member at only two places. Elongate aggregates of ovoid pellets from near Snow Settlement (loc. 1, pl. 1, USGS loc. 4133) were identified as Tomaculum cf. T. problematicum Groom by Häntzschel (Pavlides, Neuman, and Berry, 1961, p. B66). This fossil was first described from the Lower Ordovician (Tremadoc)

${ }^{3}$ On July 11, 1965, the writer discovered a Silurian graptolite fauna of both monograptids and climacograptids near the top of the ribbon rock member of the Meduxnekeag Formation along a new roadcut in the Smyrna Mills quadrangle, Maine (fig. 1). W. B. $\mathbf{N}$. Berry examined this collection and dates it as Early Silurian, about coeval to British Zones 18 and 19 (written commu., July 19, 1965). Thus the age of the ribbon rock member of the Meduxnekeag Formation ranges from Middle Ordovician to Early Silurian. This new age range should be noted where reference is made to the Ordovician age of the Meduxnekeag (text and pl. 1). 
Bronsil shales of England (Groom, 1902). Penau (1941) illustrates similar structures from Ordovician rocks in Germany and notes their occurrence in Ordovician rocks of Czechoslovakia, France, and England.

At locality 2 (USGS loc. 4134), west of the North Branch Meduxnekeag River (pl. 1), large boulders, like the adjacent outcrops of ribbon rock, yielded a few minute brachiopods and other fossils, largely unidentifiable, from thin sandy layers intercalated with calcareous siltstone.

\section{NINE LAKE FORMATION}

A few scattered outcrops of graywacke and slate of the Nine Lake Formation are present in a narrow strip along the northwest edge of the Bridgewater quadrangle. These rocks are contiguous with similar rocks to the west in the Howe Brook quadrangle which were originally mapped as belonging to the lower part of the Hovey Formation (Pavlides, 1962, pl. 1), but subsequently were renamed the Nine Lake Formation of the Hovey Group and dated as of Ordovician or Silurian age (Pavlides, 1964).

\section{DUNN BROOK FORMATION}

Volcanic rocks on and near Nineteen Mountain in the northwestern part of the Bridgewater quadrangle constitute a suite that is similar to the volcanic rocks originally assigned to the Dunn Brook Member of the Hovey Formation (Pavlides, 1962). Subsequently (Pavlides, 1964), the name Dunn Brook was given formational rank and removed from the Hovey Formation.

The Dunn Brook Formation on Nineteen Mountain consists of altered volcanic rocks of several kinds including fragmental rocks such as tuffs and mixtures of volcanic conglomerate and breccia, finegrained volcanic rocks with lithic fragments, and rhyolitic rocks. Minor amounts of sedimentary rocks are locally interlayered with these volcanic rocks.

There is no pronounced localization of any one rock type anywhere within the areas underlain by the Dunn Brook Formation in the Bridgewater quadrangle. Generally, however, the fragmental volcanic rocks on Nineteen Mountain and near Collins Ridge (pl. 1) appear to be at the base of the Dunn Brook Formation. Most crop out east and south of the folded greenstone sills(?) of the Spruce Top Greenstone which, in part, outline the syncline containing the Dunn Brook Formation. Aphanitic rhyolite generally fills the core of the syncline between the greenstone sills. The fine-grained rocks with lithic fragments and the admixed sedimentary rocks occur both with the fragmental volcanic rocks and with the rhyolite. Frag- 
mental volcanic rocks and sedimentary rocks, but no rhyolite, have been found in the Dunn Brook Formation west of the north-south fault (pl. 1).

The Dunn Brook Formation is estimated to be about 2,000 feet thick in the Bridgewater quadrangle.

\section{FRAGMENTAL VOLCANIC ROCKS}

Fragmental volcanic rocks commonly are dark green to light green, and locally may have rust-weathered surfaces. Generally, they are rudely to well cleaved. Tuffaceous rocks are slaty or finely granular and are difficult to distinguish in the field from sedimentary slate and sandstone. Some of the slaty tuffs are aphanitic and break with a subconchoidal fracture, especially when broken at a large angle to cleavage.

Slaty tuffs have an indeterminate, fine micaceous groundmass which closely resembles the argillaceous matrix of slate. Poorly sorted, rounded to angular quartz and angular to subrounded feldspar grains are embedded in the groundmass. The rock normally lacks layering. Chalcedonic quartz and limonite commonly fill original cavities in the rock. Shards have never been conclusively identified in tuff or other volcanic fragmental rocks. If present originally, they have been destroyed or altered by later folding and metamorphism. Small triangular-shaped quartz fragments present in some of these rocks may be pseudomorphs of original shards. Rounded quartz grains in slaty tuff may in part indicate that both tuffaceous and sedimentary detritus were deposited together.

Some of the slaty fragmental volcanic rocks are altered and sheared lithic tuff composed of slate and volcanic rock chips, quartz, and feldspar embedded in a very fine grained groundmass. In one thin section, the volcanic lithic fragments appear to be chloritized chips of volcanic glass.

Granular tuff closely resembles impure sedimentary sandstone. However, tuff contains a cryptocrystalline quartzose groundmass that encloses quartz, feldspar, and lithic fragments of tuff, trachyte, and slate. Some of the feldspar and quartz grains have corroded outlines similar to magmatically corroded crystals in igneous rocks. Chlorite and carbonate are common minor constituents and locally replace and embay some of the mineral grains. Such rocks resemble altered mixed crystal and lithic tuff.

Coarse-grained fragmental volcanic rocks on and near Nineteen Mountain normally consist of cobble- to sand-sized lithic fragments (fine sand- and silt-sized grains are visible in thin sections) embedded in a rudely foliated argillaceous groundmass. The lithic fragments are of slate or volcanic rocks that are angular to round 
and are not arranged in any recognizable layering. Many of the elongate rock chips, however, lie with their long dimension parallel with the regional cleavage. Normally, volcanic breccia and conglomerate are characterized respectively by the angularity and roundness of lithic fragments. The presence of both angular and rounded lithic fragments indicates that the Nineteen Mountain rocks are mixtures of volcanic conglomerate and breccia. Rounded quartz grains are also present in some rocks (fig. 6). The groundmass is generally indeterminate matter. One fragmental volcanic rock contains volcanic chips embedded in a volcanic groundmass consisting of microspherulites of chert and chlorite-filled irregular vesicles which apparently have been flattened into nearly ellipsoidal shapes (fig. 7).

Bedrock exposures are too small and discontinuous to reveal the relationships of the volcanic conglomerate or breccia to the enclosing rocks and to each other. The lack of sorting and stratification, the lithic composition, and the admixture of rounded and angular fragments indicate that these fragmental volcanic rocks may have originally formed, as part, as ash flow deposits (Ross and Smith, 1961) or as laharic deposits.



Figure 6.-Photomicrograph of a mixed volcanic conglomerate and breccia. The two largest fragments are volcanic rock chips. Quartz is present chiefly as rounded grains in lower left and upper right. The other large grains in the photograph are chiefly plagioclase. Plane-polarized light. 


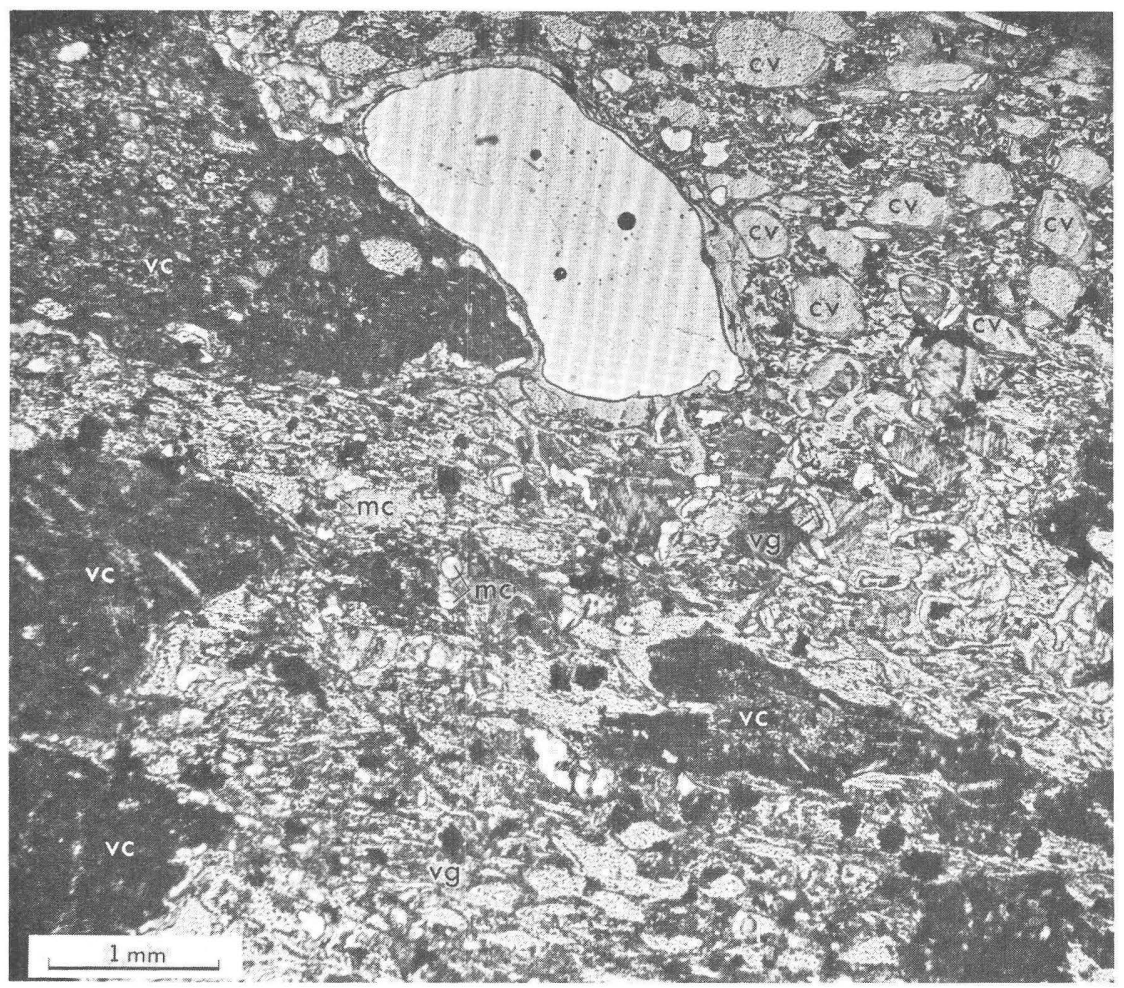

FIGURE 7.-Photomicrograph of a fragmental volcanic rock containing volcanic chips ( $v c$ ) embedded in a volcanic groundmass ( $\mathrm{g})$, microspherulites of chert $(\mathrm{mc})$, and flattened ellipsoidal chlorite-filled vesicles (cv). Plane-polarized light.

FINE-GRAINED VOLCANIC ROCKS CONTAINING LITHIC FRAGMENTS

Fine-grained volcanic rocks containing lithic fragments are only recognizable as such by thin-section examination. In the field, they appear as dense brittle dark-gray to green aphanites, and commonly have a cream-white weathered rind as much as half an inch in thickness.

Thin sections of such rocks generally show a fine-grained to cryptocrystalline quartzose groundmass that has abundant chloritic flakes. Embedded within the groundmass are feldspar, quartz, and irregularly shaped lithic fragments. Albite- and calcite-filled amygdules are abundant locally. The lithic fragments range from angular to rounded and consist of altered volcanic rocks such as tuff and trachyte, as well as of slate. In one rock numerous irregular large shreds of weakly birefringent chlorite appear to contain remnant outlines of spherulitic structures, and these shreds may be chloritized volcanic glass fragments. 
The origin of such rocks is uncertain; they resemble effusive rocks in which lithic fragments become incorporated either in the original vent or after the rocks spilled on the surface as flows.

\section{RHYOLITIC ROCKS}

The rhyolitic rocks of the Nineteen Mountain region are characteristically gray, in contrast to the other volcanic rocks, which commonly are different shades of green. They are typically tough dense flinty aphanite that break with a subconchoidal or hackly fracture and which characteristically have a well-formed white to creamwhite weathered rind as much as half an inch thick. Locally some of the rocks have a spotted appearance on fresh surfaces and a few have irregular small vesicles.

The aphanitic rhyolite in thin section has a fine-grained to cryptocrystalline quartzose groundmass, generally speckled with fine flakes of chlorite and white mica, and larger grains of feldspar and quartz. Leucoxene-coated sphene is an abundant fine-grained accessory in some of the rocks. In others, carbonate is abundant and apparently fills irregular cavities. Except for the absence of lithic fragments, aphanitic rhyolite generally is petrographically similar to the finegrained rocks containing lithic fragments.

\section{ADMIXED SEDIMENTARY ROCKS}

Various types of sedimentary rocks are irregularly admixed with the volcanic rocks of Nineteen Mountain and its immediate vicinity. Slate occurs at one place, as a dark gray-blue, finely laminated rock which in thin section consists of silt-sized quartz mixed with an indeterminate micaceous paste. The slate contains irregular streaks and masses of carbonaceous matter and small subspherical chert nodules. Elsewhere, somewhat phyllitic slate occurs as a dark-gray rudely foliated rock composed of fine micaceous matrix that contains small elongate leucoxene-coated grains and encloses highly folded and disrupted chert laminae.

Siltstone occurs as light-gray finely granular rock or as graygreen dense rock that is irregularly and indistinctly layered. In thin section the granular siltstone consists essentially of silt-sized quartz. White mica is a common minor constituent and a large magnetite porphyroblast having wavy lamellar quartz in pressure growths is present in one rock. Quartz-filled gash fractures are common microscopic features. Dense siltstone appears in thin section as an irregularly layered quartzose rock which has abundant microfaults offsetting the layers. Some layers contain carbonaceous inclusions and spherical chert nodules similar to the carbonaceous slate described earlier. Chert also forms thin crosscutting veinlets. 
Gray impure micaceous sandstone is also present, and in thin section shows angular to subangular sand- to silt-sized quartz (major constituent) and feldspar grains (minor constituent) set in a finely quartzose matrix that includes minor amounts of sericite. Such rocks appear to be arkose rather than graywacke.

The age of the Dunn Brook Formation is not precisely known; it is not younger than Silurian and parts of it may be pre-Silurian. This age is based on information now available in the Howe Brook quadrangle (fig. 1) at Hovey Brook (Pavlides, 1962, loc. A of pl. 1, USGS locality 6048-SD). This locality contains brachiopods including Meristina that indicate a Silurian age (A. J. Boucot, written commun., 1962). The fossils occur in tuffaceous sandstone that is locally conglomeratic and overlies the volcanic rocks of the Dunn Brook Formation. Hence the Dunn Brook may be of the same age as the Meristina-bearing layers, or of Ordovician age. It cannot be older than Ordovician for it contains crinoidal debris at a few places (Pavlides, 1964).

\section{QUARTZITE AND SLATE}

Sand- and silt-sized clastic rocks and minor amounts of slate crop out only in a few places in the northwest part of the Bridgewater quadrangle, but numerous angular blocks of float suggest that such rocks are relatively widespread here. The available exposures suggest these rocks have a rather uniform northeast strike. They are believed to be in fault contact with the more folded and lithologically diverse rocks of Ordovician and Ordovician(?) or Silurian(?) age which lie southwest of them. The possibility exists, nonetheless, that the contact with the rocks to the southeast, rather than being a fault, is an unconformity.

Rocks of this unit have gray and gray-green colors of different brilliance. They mostly are massive or faintly layered micaceous quartzite and siltstone which may or may not be calcareous. Thin beds and minor amounts of slate float are also present. Load casts (Kuenen, 1953b, p. 23) along mutual bedding plane surfaces between sandy and slaty beds are present locally as small-scale features but are recognizable chiefly on polished surfaces of rock and therefore are not readily observable in natural exposures.

Table 3 lists modal analyses of three clastic rocks from this unit. The scarcity of lithic fragments in these graywackes represents a characteristic difference between this suite of clastic rocks and the other formations in this region.

Lithologic equivalents of these apparently unfossiliferous rocks have not been found elsewhere in the Bridgewater quadrangle, hence at present, they cannot be assigned a stratigraphic position and are

$773-6430-65-5$ 
mapped as an unnamed unit of quartzite and slate (pl. 1). However, to the northeast in the Mars Hill quadrangle (fig. 1) and about on strike with this belt of rocks, fossils have been found in limy siltstone by Mr. William Forbes, amateur paleontologist of Washburn, Maine (USGS loc. 6836-SD). Mr. Forbes' collection was examined by A. J. Boucot who identified the brachiopod Isorthis cf. $I$. arcuaria and who considers this fauna to be of Silurian (early Ludlow) age (written commun., 1963). Within the Bridgewater quadrangle, the quartzite and slate unit is estimated to be more than 4,000 feet thick (table 1).

TABLE 3.-Modal analyses of graywacke from quartzite and slate unit

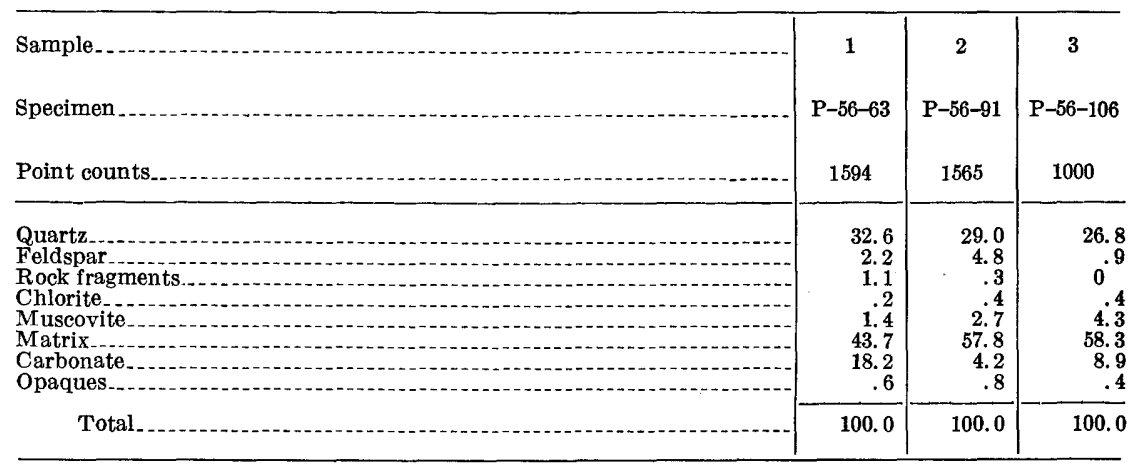

Ternary composition

\begin{tabular}{|c|c|c|c|}
\hline $\begin{array}{l}\text { Quartz... } \\
\text { Feldspar } \\
\text { Rock fragments. }\end{array}$ & $\begin{array}{r}91.0 \\
6.0 \\
3.0\end{array}$ & $\begin{array}{r}85.0 \\
14.1 \\
.9\end{array}$ & $\begin{array}{l}96.8 \\
3.2 \\
0\end{array}$ \\
\hline Total & 100.0 & 100.0 & 100.0 \\
\hline
\end{tabular}

\section{Location of specimens}

1. P-56-63, within the Mars Hill quadrangle about 2.63 miles, N. $19^{\circ} 00^{\prime}$ W. from the northwest corner of Cox Patent.

2. P-56-91, about 2.83 miles N. $70^{\circ} 00^{\prime} \mathrm{W}$. from the northwest corner of Cox Patent.

3. P-56-106, within the Howe Brook quadrangle about 3.41 miles, N. $82^{\circ} 00^{\prime} \mathrm{W}$. from the northwest corner of Cox Patent in the Bridgewater quadrangle.

\section{BELL BROOK FORMATION}

The Bell Brook Formation as herein defined is present in the west-central and southwestern parts of the Bridgewater quadrangle. It is named after Bell Brook in the central part of T.C., R. 2., which contains extensive exposures of this formation from its mouth to about 1 mile upstream. Two units comprise the Bell Brook Formation; the older conglomerate unit crops out in the southwest corner of the Bridgewater quadrangle and is chiefly exposed in a faulted northwest-trending anticline whereas the younger slate unit is more extensive and generally more complexly deformed. 
The relative ages of the conglomerate and slate units of the Bell Brook Formation are based on the apparent structural relationships of the two units along South Brook and nearby areas in the southwest part of the Bridgewater quadrangle. Here the conglomerate member is characterized by gentle dips and appears to underlie the slate member conformably.

The conglomerate member is estimated to be about 5,000 feet thick (table 1). It has been recognized in southern Aroostook County only in the small area in and around the southwest corner of the Bridgewater quadrangle. Like the slate and graywacke member of the Meduxnekeag Formation, it also may be a lenticular unit that wedges out rapidly. The slate member is about 6,000 feet thick (table 1). Hence, the total thickness of the Bell Brook Formation is probably at least 11,000 feet.

\section{CONGLOMERATE MEMBER}

The older unit of the Bell Brook Formation typically is grayishgreen or light-green thick-bedded to massive granule conglomerate locally interbedded with graywacke and slate. The conglomerate generally ranges in grain size from 2 to $4 \mathrm{~mm}$, although there are a few larger sized fragments commonly present and sand- and siltsized grains are present in the matrix. Locally, the granule conglomerate grades to pebble conglomerate in which the bulk of the fragments exceed $4 \mathrm{~mm}$ in size though none are larger than $7 \mathrm{~cm}$. Grains range from well rounded to subangular in shape. Graded beds present in some conglomerate, commonly consist of pebble or granule conglomerate at the base of the layer and grade upward to finer sizes of sand. Such graded beds range from a few inches to several feet in thickness.

Granule and pebble conglomerate beds are composed chiefly of rock fragments and quartz. Black slate and gray or greenish chert and aphanite chips are distinctive in hand specimen. In some beds little matrix is present; under high magnification in thin section, pale-green films of chlorite normally surround individual grains and also separate grains from each other. A great variety of lithic fragments such as slate, altered rhyolite and trachyte, granite, siltstone, quartzite and chert, is generally present. Quartz, both strained and unstrained, is always present; plagioclase is common and is normally scaled with minute chlorite or sericite flakes. Carbonate (iron-stained) occurs in irregular patches throughout the rock or as an alteration on mineral grains. In some rocks muscovite and chlorite occur as distinct flakes larger than the finely divided mica and chlorite of the matrix and are believed to be later minerals formed through metamorphism. Among the minor constituents present are sphene, zircon, and tourmaline. 
Graywacke associated with the conglomerate occurs either as massive or graded interbeds or as the sand-sized portion of graded beds of conglomerate; the latter generally are lithic graywacke and contain more quartz and more matrix than the conglomerate fraction. Graywacke in distinct interbeds within the conglomerate member has a range in composition which includes quartz, lithic, and feldspathic graywacke (fig. 2). Table 4 lists modal analyses from a bed of quartz graywacke and a bed of lithic graywacke. The rock fragments in the graywacke are normally similar to that in the conglomerate.

Green slate, similar to that of the slate member of the Bell Brook Formation (described below), is also present as local interbeds. Dark gray, chloritic and carbonate-bearing siltstone layers also occur locally.

TABLE 4.-Modal analyses of graywacke from the Bell Brook Formation

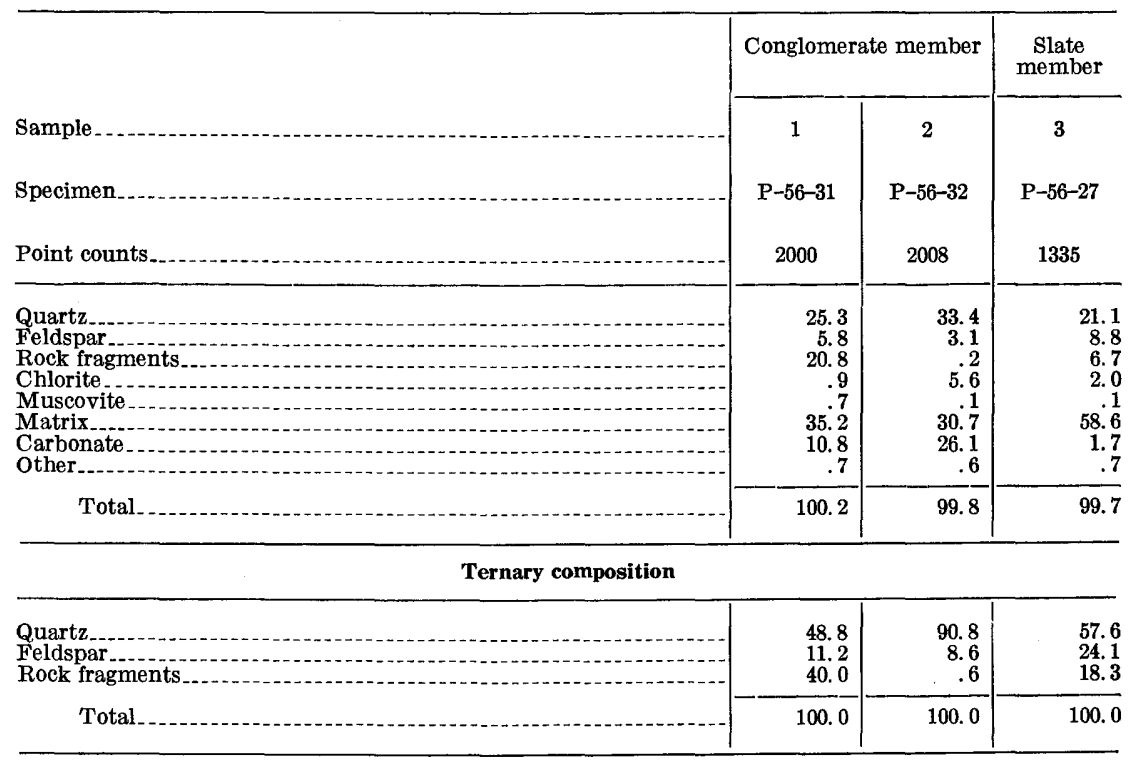

\section{Location of specimens}

1. P-56-31, along the South Brook about 3.72 miles N.72 $30^{\prime} \mathrm{W}$. the southeast corner of T.C., R. 2.

2. P-56-32, along the South Brook about 3.72 miles N.72 $30^{\prime}$ W. the southeast corner of $T$.C., R. 2.

3. P-56-27, along the North Branch Meduxnekeag River about 2.57 miles $\mathrm{S} .24^{\circ} 30^{\prime} \mathrm{W}$. from the northeast corner of T.C., R. 2 .

\section{SLATE MEMBER}

Slate and siltstone, ranging in color from greenish gray to light olive gray and pale olive, characterize much of the slate member of the Bell Brook Formation. Pale-yellowish-brown laminae are minor but relatively common features. Olive-colored slate commonly breaks along subconchoidal fractures. At some places where slaty cleavage 
is strongly formed, the slate breaks into long thin pencillike fragments. Tan- to buff-weathered dolomitic limestone layers, which on fresh surfaces are greenish gray to dark greenish gray, are locally present as interbeds a few inches to a few feet thick within the slate and siltstone unit. Medium-gray to light-medium-gray siltstone and very fine quartzite are also abundant in this unit. Such rocks may or may not be calcareous. Greenish-gray graywacke, ranging in thickness from a few inches to a few feet also is irregularly distributed, generally as local interbeds. Less commonly, conglomerate similar to that of the conglomerate member is also present at a few places. The slate and siltstone are generally unweathered, but are commonly coated with thin films of black manganese oxide and brown iron oxide. Graded bedding in the siltstone is present locally but it is generally difficult to observe because of the fineness of grain size of the rocks. At some places the bedding is recognizable by the refraction that slaty cleavage undergoes in passing from layer to layer. Convolute or curled bedding is present in some siltstone layers, and at one place the convoluted layering is truncated sharply by an even-bedded layer, proving that convolution formed here as a sedimentary feature.

On Wellington Ridge (pl. 1) argillite that locally appears to have been thermally metamorphosed is a less common lithology of the slate member.

The olive-colored slate of the Bell Brook Formation chiefly consists of a matrix of fine chlorite and muscovite flakes and very fine grained quartz. Many of the muscovite and chlorite flakes lie along the original sedimentary layering of the rock.

The siltstone consists chiefly of silt-sized subangular to subround quartz grains cemented by a chloritic and sericitic matrix. Carbonate is generally an abundant very fine grained constituent; its indices of refraction are above that of canada balsam, and X-ray diffraction analyses of bulk rock samples indicates that it is of the dolomite type. The typical buff to tan weathering of these rocks, resulting from oxidation of the carbonate and the optical and X-ray features, indicates that the carbonate is either ferroan dolomite or ankerite. Plagioclase is also present in the siltstone, being recognized both in thin section and in the X-ray diffraction curves of bulk rock samples. Sphene and zircon are minor minerals.

Dolomitic limestone layers are mainly composed of very fine grained ferroan dolomite or ankerite as determined by microscopic and $\mathrm{X}$-ray methods described above. Round to subround quartz silt is a common minor constituent in such limestone, as are fine flakes of muscovite and chlorite that are also present in minor amounts.

The graywacke beds of the slate member show a wide range in 
composition similar to those of the conglomerate member. A modal analysis of a feldspathic graywacke from the slate member is listed in table 4 (No. 3) and is plotted on figure 2. One notable feature of the graywacke beds of the slate member along Howard Brook east of the north-trending fault in T.C., R. 2., (pl. 1) is the presence of bent and broken, partly chloritized biotite. Pyrite is also locally abundant in some of the graywacke beds here.

Slate of the Bell Brook Formation in southwestern Monticello Township and northwestern Littleton Township is dark gray, finely laminated, and noncalcareous and has local silty layers. The slate immediately west of the south end of the dacite-diorite dike locally contains about 400 feet of granule conglomerate and minor graywacke beds. The granule conglomerate is poorly exposed here, and its presence is indicated mostly by large boulders of float.

The Bell Brook Formation may overly the Meduxnekeag Formation unconformably, at least locally. Evidence for such unconformity, however, is sparse and indirect. About half a mile south of Meadowbrook Pond, along the North Branch of the Meduxnekeag River in the northeast part of T.C., R. 2. (pl. 1), ribbon rock of the Meduxnekeag Formation crops out in a small complexly deformed anticline. Slate of the Bell Brook Formation, which has a persistent northeast strike and steep northwest dip, is discontinuously exposed to the southeast and northwest of the ribbon rock at distances ranging from 100 to 500 feet. The marked difference in deformation between the rocks of the Meduxnekeag and Bell Brook Formations here may indicate unconformity. A structural difference between the two formations is also present at the northeast end of the Bell Brook Formation (pl. 1), where ribbon rock of the Meduxnekeag Formation strikes at a markedly large angle to the general strike of Bell Brook Formation beds. Graded bedding within the Bell Brook Formation here also indicates that it overlies the Meduxnekeag Formation.

The age of the Bell Brook Formation is uncertain. Only two fossil localities have been found in this unit in the Bridgewater quadrangle and both are from the slate member. One small dalmanellid brachiopod and an indeterminate fragment of another brachiopod have been found at locality 3 (USGS loc. 6821-SD). The age of these brachiopods is virtually indeterminate, for they have a range from post-Early Ordovician to pre-Mississippian times (R. B. Neuman, written commun., 1960). Ribbonlike and branching gray markings parallel bedding surfaces of finely laminated tan-weathered siltstone at locality 4 (USGS loc. D448). "The ribbonlike forms are about $5 \mathrm{~mm}$ wide; no complete specimens were found but some incomplete specimens are as long as $12 \mathrm{~cm}$. The branching forms 
are about $2 \mathrm{~mm}$ wide, with an irregular but largely radial pattern of two- to five-fold branches. These markings are probably burrows, and do not aid in dating the Bell Brook Formation" (Neuman and Mamay, written commun., 1962).

Lithologically the slate member of the Bell Brook is somewhat similar to the Swanback Formation of the Presque Isle quadrangle which has been dated as of Early Devonian age (Boucot and others, 1964b). In 1960 the writer discovered a limy sequence of fossiliferous rocks in the northwest part of the Houlton quadrangle in an area generally underlain by slate of the Bell Brook Formation. The stratigraphic relationship of these limy rocks to the nearby slate of the Bell Brook is not clear because of the poor exposures; the limy rocks may either be interbedded with the Bell Brook or may overlie it. These limy rocks are of Early Devonian age on the basis of the New Scotland fossils they contain (A. J. Boucot, written commun., 1961).

Although the slate member therefore may be, in part, of Early Devonian age, the precise age of the underlying, structurally conformable conglomerate member is even more uncertain. However, because of its apparent structural conformity with the slate member, the conglomerate member is assumed to be younger than any pulse of the Taconic deformation that may have affected the region. The Taconic disturbance apparently was not synchronous everywhere in New England and the Maritime Provinces of Canada. It was more of a discontinuous orogenic episode characterized by different intensities and times of occurrence at different places. Roughly, it spans Middle Ordovician through Early Silurian time (Boucot and others, 1964 b, p. 88-93).

The conglomerate member of the Bell Brook Formation has certain lithologic similarities to the conglomeratic facies of the socalled "Sheridan" "Sandstone (Williams and Gregory, 1900, p. 133), now renamed the Frenchville Formation and which has a brachiopod fauna that may range from the $\mathrm{C}_{3}$ zone or younger of the upper Llandovery to Wenlock age which is about Middle Silurian (Boucot and others, 1964b).

The age of the Bell Brook, therefore, is herein tentatively designated as of Devonian (?) and Silurian (?) age or both; it may include rocks of post-Taconic age through Early Devonian (New Scotland) age.

\section{COBBLE CONGLOMERATE}

A distinctive local massive cobble conglomerate crops out near and at the crest of two small hills in T.E., R. 2, in the northwestern part of the Bridgewater quadrangle. This conglomerate contains a great

\footnotetext{
${ }^{4}$ Name preempted by earlier use for a Precambrian formation in Yellowstone Park.
} 
variety of rock fragments, such as slate, siltstone, granite, greenschist, and felsite. Quartz is common (including milky quartz) and feldspar is present in small amounts. The mineral and rock grains are characteristically well rounded and range from cobble down to granule sizes. In thin section, the matrix consists of finely comminuted quartzose grains and chlorite.

The conglomerate is unfossiliferous, lacks bedding, and is poorly exposed; thus, its stratigraphic and structural relationship to the surrounding rocks cannot be determined. It is estimated to be about 120 feet thick (table 1). On the lower slopes of the hill where the conglomerate crops out, graywacke boulders are present, but whether such graywacke belongs with this conglomeratic unit or is graywacke of the slate and graywacke member of the Meduxnekeag Formation has not been established. Because of the presence of cobbles of many rock types, some of which appear to have been derived from older units in the region such as the Spruce Top Greenstone of Ordovician(?) to Devonian(?) age, this conglomerate is believed to be relatively younger, possibly of Devonian age, and may overlie the slate and graywacke member of the Meduxnekeag unconformably.

\section{INTRUSIVE ROCKS OF UNCERTAIN AGE}

Intrusive igneous rocks are present as small masses at many places in the Bridgewater quadrangle. Most of these rocks are clearly discordant to the sedimentary rocks they intrude, occurring either as dikes or small plutons. Some of the greenstones, however, appear to be concordant sills within the Dunn Brook Formation. A narrow aureole of hornfels generally surrounds the larger dikes and plutons where they are emplaced in impure limy rocks.

\section{SPRUCE TOP GREENSTONE}

Greenstone crops out along the summits and flanks of Nineteen Mountain and Collins Ridge in the northwestern part of the Bridgewater quadrangle. It is similar to greenstone of the Spruce Top Greenstone in the Howe Brook quadrangle to the west. The greenstone of Collins Ridge was assigned to the Spruce Top earlier (Pavlides, 1962, pl. 1). The general distribution of greenstone in the Bridgewater quadrangle, however, was not well known at that time. Recent road building has furnished additional bedrock exposures that require modification of the geologic interpretation here. The parental rocks of the greenstone on Collins Ridge were originally believed to be emplaced as sills in both the Meduxnekeag and Hovey Formations. In this report, however, the greenstone of Collins Ridge is separated from the Meduxnekeag and along with the greenstone on Nineteen Mountain, is considered to be sills within the Dunn Brook Formation. No evidence was found to indicate 
whether this greenstone was of intrusive or extrusive origin, but it is thought to occur in sills because of its similarity to greenstone which occurs at different stratigraphic levels in the Howe Brook quadrangle to the west and which is provisionally considered to be in sills rather than flows (Pavlides, 1962). Locally, at the north end of Nineteen Mountain ( $\mathrm{pl} .1$ ) volcanic rocks and greenstone appear to interfinger in a complex manner. Because of the scale of the map, the small size of such interfingering, and the generally poor exposures here, the contact is shown in a generalized manner as smpoth. Some volcanic rocks appear to be enclosed within the greenstone mass on Nineteen Mountain and may be country rock interleaved within the greenstone sill. However, the greenstone here may comprise only a few thin sills and the bulk of the rocks may be actually volcanic rocks; hence, the amount of greenstone may be more limited than the generalized mass shown on plate 2. The tabular masses of greenstone in the Bridgewater quadrangle may be as much as 1,500 feet thick (table 1 ).

The Spruce Top greenstones of Nineteen Mountain and of Collins Ridge normally are massive aphanites and phanerites of various shades of dark greenish gray. They may or may not be jointed, but they are not cut by the regional slaty cleavage that characterizes the other rocks of this area.

The age of the Spruce Top Greenstone is uncertain. Originally it was assigned a Silurian(?) age because of its apparent relationship to other rocks in the Howe Brook quadrangle (Pavlides, 1962). However, the Spruce Top Greenstone is now known to be restricted mostly to rocks of Ordovician(?) or Silurian(?) age in the Bridgewater (Dunn Brook Formation of pl. 1) and Howe Brook quadrangles. The Spruce Top Greenstone may be of approximately the same age as these rocks or it may have been intruded into them at any time after they formed. If indeed the Spruce Top Greenstone occurs mostly as sills, it could not have been emplaced as such after the Lower Devonian, because it is folded conformably with the enclosing sediments. This episode of folding (Acadian orogeny) appears to have occurred near the close of the Lower Devonian (Boucot and others, 1964b). Hence, the Spruce Top Greenstone may be of Ordovician(?) to Devonian(?) age.

The mineralogy of the greenstones of the Spruce Top has been described previously (Pavlides, 1962, p. 24-28) and is generally applicable to all the greenstones in the northwestern part of the Bridgewater quadrangle. Table 5 lists modal analyses of eight greenstones from this area. The extensive alteration, and the difficulty of identifying the minerals in these rocks, limits these analyses to orders of magnitude of the mineral composition of the greenstones 
rather than to precisely measured percentages. The counts are listed to the nearest tenth only to maintain internal arithmetic consistency in the table; they have no quantitative significance.

The essential minerals in these rocks are albitic plagioclase, pyroxene, chlorite, and sphene although a wide range exists in the actual content of these minerals in any particular greenstone (table 5).

Sodic plagioclase normally occurs as groundmass laths, and less commonly as large phenocrysts or in glomeroporphyritic habit. Optical properties such as extinction angle against albite twins, optically positive character, and refractive indices (mostly below, or, in a few places, close to or barely above that of canada balsam) indicate that such plagioclase ranges from albite to sodic oligoclase. This plagioclase occurs rarely as nearly clear crystals; more commonly it is scaled by chlorite flakes, or is extensively replaced by chlorite and epidote.

TABLE 5.-Modal analyses of greenstone from the Spruce Top Greenstone from Collins Ridge and Nineteen Mountain

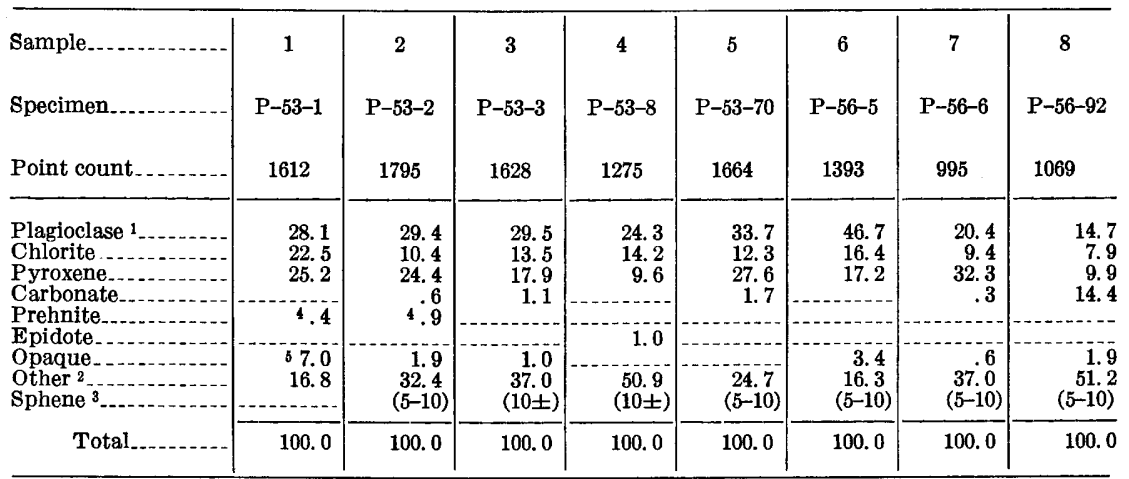

1 Plagioclase is mostly albite, albite-oligoclase or oligoclase.

2 Commonly includes unidentifed material, sphene, minor quartz, zoisite-clinozoisite(?) and actinolite. 2 Commonly includes unidentified material, sphene, minor quartz,
Unidentified material may contain some plagioclase and pyroxene.

3 Sphene is very abundant in most of these rocks but difficult to count separately and is included in the "other" constituents. Ranges of abundance of sphene are parenthetically included but are not counted as

part of the total.
4 Prehnite occurs exclusively in veinlets in these modal analyses; however, it also is present in a few vesicles in $\mathrm{P}-53-2$, but these vesicles did not fall within the point count tabulation.

${ }^{5}$ Mostly ilmenite in various stages of alteration to leucoxene-coated sphene.

\section{Location of specimens}

1. P-53-1, from the southeast hill of Collins Ridge about 2.37 miles $\mathrm{S} .58^{\circ} 30^{\prime} \mathrm{W}$. from the northwest corner of Cox Patent.

2. P-53-2, from the southeast hill of Collins Ridge about 2.33 miles S. $59^{\circ} 00^{\prime} \mathrm{W}$. from the northwest corner of Cox Patent.

3. P-53-3, from the northeast hill of Collins Ridge about 2.16 miles $\mathrm{S}^{-} 62^{\circ} 30^{\prime} \mathrm{W}$. from the northwest corner of Cox Patent.

4. P-53-8, about 2.63 miles S. $82^{\circ} 30^{\prime}$ W. from the northwest corner of Cox Patent.

5. P-53-70, from the south slope of a hill (known locally as Porcupine Hill) about 3.37 miles $\mathrm{S} .62^{\circ} 00^{\prime} \mathrm{W}$.

from the northwest eorner of Cox Patent.
6. P-56-5, from Nineteen Mountain about 1.82 miles N. $76^{\circ} 00^{\prime}$ W. from the northwest corner of Cox Patent.

7. P-56-6, from Nineteen Mountain, about 1.85 miles N. $75^{\circ} 00^{\prime} \mathrm{W}$. from the northwest corner of Cox Patent.

8. P-56-92, about 2.60 miles S. $78^{\circ} 30^{\prime}$ W. from the nortwest corner of Cox Patent. 
Pyroxene normally occurs as short stubby laths but it also ophitically encloses plagioclase, as on the southeast hill of Collins Ridge. Colorless augite is the most common pyroxene present; a colorless pyroxene with small $2 \mathrm{~V}$ and weak to moderate birefringence occurs in a few rocks and may be pigeonite. One of the striking features of the pyroxene of the greenstones on Collins Ridge and Nineteen Mountain is that, except for some minor amphibole alteration at the ends of grains, the pyroxene is all nearly fresh. This freshness contrasts with the pyroxene of some greenstone in the adjoining Howe Brook quadrangle that are considerably altered to chlorite.

Chlorite occurs as a groundmass constituent, in amygdules and veinlets, and as replacement of other minerals. It is pale green and green to yellowish green and commonly has abnormal interference colors. Both optically positive and negative varieties, that typically have small $2 \mathrm{~V}$, characterize such chlorite.

Sphene, an abundant constituent, occurs in some greenstone as pseudomorphs or partial replacement of ilmenite. Typically, however, it occurs in the groundmass, and in chloritic amygdules, as very fine granules characteristically coated with a film of leucoxene. Carbonate may be absent or be locally abundant, either as an alteration on other minerals or a vesicle filling. Prehnite occurs in the greenstone on the southeast hill of Collins Ridge (Nos. 1 and 2 of table 5) as very thin (microscopic) veinlets and in a few vesicles (No. 2 of table 5). Epidote is generally sparse and is in small irregular patches. Magnetite, pyrrhotite, and ilmenite are the common opaque minerals; normally much of the ilmenite is slightly to considerably altered to leucoxene-coated sphene. Quartz, actinolite, and an alteration mineral of plagioclase and pyroxene that may be close to zoisite-clinozoisite are present in variable but minor amounts. The actinolite normally occurs as alteration or replacement growths along the ends of pyroxene laths.

\section{MINOR GREENSTONE DIKES}

A few small, thin dikes are present in the east-central and southeastern parts of the Bridgewater quadrangle and are emplaced entirely in rocks of the Meduxnekeag Formation. The dikes consist of dark greenish-gray greenstone that is mostly massive or poorly foliated locally. Where the dikes cut noncalcareous slate of the Meduxnekeag Formation, few if any thermal effects are visible but, where the dikes intrude ribbon rock, some silicification of the country rocks has taken place. Silicification is best shown near the contacts of the dike that is exposed along the North Branch Meduxnekeag River about 1.5 miles southeast of Monticello. This dike clearly shows crosscutting relationships to the bedding of the sedi- 
mentary rocks. The dike about 4 miles northeast of Monticello appears to strike in the same direction as the cleavage of the intruded slate.

All these dikes are highly altered. Abundant chlorite is present as partial to complete alteration of plagioclase. Composition of the plagioclase cannot be determined optically. Large crystals of opaque minerals are very characteristic and many of these are ilmenite that is partly or completely altered to leucoxene-coated sphene. Quartz is present as a minor constituent and is normally unaltered. It also occurs with carbonate in thin veinlets that cut the rocks. Well-formed elongate crystals of apatite are also present.

This greenstone differs from that of the Spruce Top Greenstone in that it lacks pyroxene and contains somewhat more quartz. The original unaltered rocks of these dikes therefore were more acid than those of the Spruce Top Greenstone.

\section{SERPENTINITE}

Two small masses of antigoritic serpentinite lie along a northtrending fault in the northwest part of the Bridgewater quadrangle. The few exposures of serpentinite here are small and the outline and shape of the bodies is necessarily generalized (pl. 1). One mass lies along the crest of a hill locally known as Porcupine Hill. The other mass lies southeast of the hill and is exposed, in part, at one place along the stream that drains Ketchum Lake, along Number Nine Stream, and also immediately to the south of it. Magnesite rock is present along Number Nine Stream and at one place on Porcupine Hill. Carbonate-talc schist is exposed at a few places along the gully of the stream draining Ketchum Lake. The serpentinite "is typically composed of fine-grained fibrolamellar antigorite. Original tabular crystals of the groundmass are now generally outlined by fine-grained magnetite. $* * *$ Chrysotile is in late veinlets that crosscut the antigorite. A minor amount of euhedral to subhedral chromite is found in the antigoritic groundmass. Carbonate is common in most of the serpentinite." (Pavlides, 1962, p. 28-30, fig. 15.) The serpentinite was probably formed from the alteration of an olivine-bearing rock.

The age relationship of these rocks is not closely known. The serpentinite intrudes both the Meduxnekeag Formation of Ordovician age and the Spruce Top Greenstone of Ordovician(?) to Devonian (?) age.

\section{METAGABBRO}

Coarse-grained (locally pegmatitic) altered gabbro crops out in a few places immediately to the north of the serpentinite on Porcupine Hill. Here again the few exposures permit only a generalized 
outline of this gabbroic mass to be shown (pl. 1); it may be smaller or larger than indicated. The gabbroic rocks are chiefly composed of pyroxene and plagioclase that have an ophitic texture. Chlorite, coarse-grained sphene, carbonate, and antigorite are additional constituents. The pyroxene may be fresh, but commonly is partly to completely altered uralitically or is replaced by actinolite, by chlorite, or by both. The plagioclase normally is highly altered and the sphene is coated with leucoxene. Green chlorite may occur in the groundmass or as a replacement of pyroxene and plagioclase. Antigorite is locally present and may replace pyroxene.

The general relationships of the altered gabbroic rocks and the serpentinite are not known although they may be genetically related.

\section{GARNET PORPHYRY}

Two small bodies of garnet porphyry are present in the west-central and central parts of the Bridgewater quadrangle. The larger body, on Estabrook Hill, is intrusive into typical ribbon rock of the Meduxnekeag Formation and contains a halo of baked rocks. Hornfels is present in only minor amounts around the smaller garnet porphyry intrusive to the west; and slate that has been intruded by it has not been thermally metamorphosed.

Garnet porphyry is a coarse-grained rock; feldspar phenocrysts $10 \mathrm{~mm}$ long and red to reddish-brown garnet crystals $8 \mathrm{~mm}$ in diameter are present at a few places. Inclusions of country rock, baked to garnet-biotite hornfels, are abundant in the porphyry on Estabrook Hill, particularly along the northwest side of the pluton.

The features of garnet porphyry in thin section have been described for the smaller body of this rock (Pavlides, 1962, p. 30) :

*** The porphyry generally has a fine-grained quartzose and feldspathic groundmass with minor mica. Large phenocrysts of rounded, subspherical to irregular grains of quartz, feldspar, and probable quartz-feldspar rock fragments are the chief constituents of this rock. Commonly these constituents and particularly quartz are marginally embayed or corroded by fine-grained groundmass minerals.

The feldspars are highly altered to sericite and muscovite or clouded by kaolinite. Muscovite is a well-crystallized constituent but in many places it has altered pseudomorphously to chlorite. Commonly, the altered muscovite contains granular leucoxene-coated sphene along cleavage **** Reddishbrown biotite, generally associated with garnet, is commonly altered to pseudomorphs of chlorite. The garnet forms poikilitic grains. The margins of some of these garnets have retrogressed to chlorite; sharp dodecahedral corners of the original garnets are preserved by the chlorite rim. Carbonate is another common groundmass accessory of the porphyry, and also an alteration mineral on such minerals as feldspar. At one place pyrite is an abundant accessory both in the groundmass as well as within a muscovite mat that is pseudomorphous after a large feldspar crystal. 
The pluton on Estabrook Hill is similar in most respects to the smaller garnet porphyry mass described above. Additional features in thin section of garnet porphyry from this larger pluton are potassium-feldspar phenocrysts (with Carlsbad twins and slightly clouded by a kaolinitic and sericitic alteration) and plagioclase. Colorless phlogopite(?), characterized by a practically uniaxial negative interference figure and by positive elongation and extinction parallel to its cleavage, is also present in rocks of this pluton. Red biotite is commonly rutilated, and apatite and zircon are present as minor accessories.

The occurrence of garnet, hornfels fragments, and partially digested xenoliths in the garnet porphyry of Estabrook Hill indicates that the parent magma had assimilated aluminous country rock.

The garnet porphyry masses are undeformed and hence were formed after the regional folding and regional metamorphism. Like the rhyodacitic rocks described below they are believed to have been emplaced at some time after Early Devonian time.

Biotite from the Estabrook Hill garnet porphyry has a K-Ar age of 394 million years whereas the Pb-alpha age of zircon from this rock is 410 million years (Faul and others, 1963, Me 27 of table 1, p. 8).

\section{RHYODACITIC ROCKS}

DACITE-DIORITE DIKE

A dike about 5 miles long is present along the western side of Monticello Township (pl. 1) immediately south of Sugar Loaf. It is about 800 feet wide at its north end, about 2,000 feet wide approximately 2 miles to the south, and becomes progressively narrower to the south until it apparently wedges out. Thin and probably discontinuous masses of this dike may extend south into the Houlton quadrangle (fig. 1) because boulders of similar rock have been found along the projected strike at several places. It is unlikely that these boulders were glacially transported from the dike in the Bridgewater quadrangle, for ice movement was southeasterly and these boulders are slightly west of the main trend of the dike. At its north end, the dike probably is covered in part by the felsite of Sugar Loaf. The dike, or stringers from it, may also be present locally on the east side of Sugar Loaf, inasmuch as angular boulders of dacite have been found at a few places between the two masses of felsite.

In general, the dike is made up of a medium-grained leucocratic to mesocratic dacite, quartz dacite, and diorite, which are altered in varying degrees. The least altered rock typically consists of abundant plagioclase which, on the basis of the extinction of twin lamellae, is not more calcic than andesine. Much of the plagioclase is 
zoned and some is thinly mantled with clear untwinned albite. Quartz is present in most places, and potassium-feldspar is present in subordinate amounts.

Red and brown biotite is commonly the most abundant dark mineral of these rocks. Pyroxene is present at a few places and poikilitic garnet has been recognized in dike rocks south of the North Branch Meduxnekeag River (pl. 1). Muscovite is locally present and is generally intergrown with biotite. Accessory minerals include carbonate, sphene, apatite, tremolite(?), and ore minerals.

Alteration in the dike rocks grades from only mild sericitization of feldspar and incipient chloritization of biotite to complete sericitization of all the feldspar and alteration of nearly all the biotite and much of the garnet to pale-green penninite (anomolous Berlin blue interference colors, small $2 \mathrm{~V}$, and biaxial positive). The most highly altered rocks are those exposed along the North Branch Meduxnekeag River.

Biotite from this rock has been dated 384 million years old by the K-Ar method (Faul and others, 1963, Me 26 of table 1, p. 8).

\section{FELSITES}

Light-gray to medium-gray fragmental volcanic rocks and felsites crop out on and near Sugar Loaf in the central part of the Bridgewater quadrangle. The most widespread of the felsites of the Sugar Loaf area is rhyolite. In thin section, fluidal texture may be very pronounced, only poorly formed, or absent. Quartz phenocrysts are very abundant and under the petrographic microscope they appear embayed and corroded. Phenocrysts of potassium feldspar, including sanidine, are present, as well as andesine. Small phenocrysts of green hornblende are common but brown biotite is a minor constituent. In one rock, muscovite flakes are locally intergrown with chlorite; the rock contains biotite but no hornblende. Calcite, and most of the chlorite, typically occurs as alterations of other mineral grains. Epidote and a zeolitelike mineral are locally present.

The fragmental volcanic rocks generally contain quartz, potassium feldspar, plagioclase, and volcanic rock fragments. Biotite is locally present. Carbonate commonly replaces the groundmass as well as the crystal and lithic fragments.

The dacite-diorite dike and the felsites of Sugar Loaf are probably closely related. Along the east side of the dike about three-fourths of a mile north of the North Branch Meduxnekeag River, the contact of the dike with the baked limy rocks of the ribbon rock member of the Meduxnekeag Formation is exposed at two places. At the southernmost exposure, the dike has a rhyolitic selvage in immediate contact with the country rock and this salvage grades westward within a few feet from the contact into mesocratic crystalline diorite. 
The felsites on Sugar Loaf may be a fine-grained part of the dike. The associated fragmental felsic rocks on Sugar Loaf may be brecciated parts of the felsite mantle of the dike, or may be in part truly effusive. They may represent local rhyolitic outpouring of the rhyodacitic magma that elsewhere formed the dacite-diorite rocks of the dike and the associated selvages of rhyolite.

The rhyodacitic rocks are probably among the youngest intrusive units in the area. The dike and felsites are undeformed and not regionally metamorphosed; however, the dike cuts folded rocks of the Bell Brook Formation of Silurian(?) or Devonian(?) age or both. Because rocks of this age are post-Taconic they must have been folded by the Acadian orogeny, which has extensively deformed rocks of Silurian and Devonian age elsewhere in Maine. The first intensive phase of the Acadian orogeny in northern Maine is now believed to have started in uppermost Early Devonian time (Boucot and others, 1964b) ; therefore, the rhyodacitic rocks of the Bridgewater quadrangle could have been emplaced at any later time.

\section{ALTERNATIVE STRATIGRAPHIC POSSIBILITIES}

The absence of fossils in many stratigraphic units of the Bridgewater quadrangle makes most age assignments largely dependent on indirect evidence and therefore of a tentative nature. Furthermore, at many places there is a lack of clear-cut evidence from structural features that unequivocally establish the relationship of different units to each other. Thus, interpretations of the stratigraphy are possible other than the sequence just described. For example, all the rock units of the Meduxnekeag Formation are tentatively considered to be of similar age because they appear to enclose conformably or to interfinger with the ribbon rock member of Ordovician age. However, the slate and graywacke member of the Meduxnekeag Formation may be distinctly older than the ribbon rock member and the two may be separated by a disconformity. It is also possible that the volcanic rocks of Nineteen Mountain and Collins Ridge herein assigned to the Dunn Brook Formation are not coeval with similar rocks in the Howe Brook quadrangle (Pavlides, 1962, p. 17-21), but rather are a volcanic unit within the slate and graywacke member of the Meduxnekeag Formation. This, of course, would change the structural interpretation of the volcanic rocks from synclinal to anticlinal, but the evidence for the structural relationship between the volcanic rocks and the sedimentary rocks here is not firmly established inasmuch as all the layered rocks dip steeply or are vertical, and only a few top-facing directions are known.

Some of the lenses of slate believed to be enclosed by ribbon rock of the Meduxnekeag Formation may actually occur at the top of this 
member and may be equivalent to the slate member that overlies the ribbon rock member in T.D., R. 2. Furthermore, the slate member at the top of the Meduxnekeag may disconformably overlie the ribbon rock member and may be younger than Ordovician or may even be time transgressing from Ordovician to a younger age.

Another alternative stratigraphic interpretation is possible for the rocks on Wellington Ridge that have been considered as part of the Bell Brook Formation, although they are not lithologically identical with typical Bell Brook rocks. Part of this dissimilarity results from the thermal metamorphism that appears to have affected the rocks on Wellington Ridge (pl. 1). However, these rocks may be a separate lenticular facies of argillite within the Bell Brook Formation. They may even be older rocks, coeval with the Pyle Mountain Argillite of Late Ordovician (Ashgillian) age in the Presque Isle quadrangle (Boucot and others, 1964b).

\section{QUATERNARY DEPOSITS}

Surficial deposits within the Bridgewater quadrangle were examined generally incidental to the mapping of the bedrock geology. Consequently, no attempt was made to map contacts between different types of surficial deposits, except insofar as such contacts could be discerned directly from the topographic base map and aerial photographs, or distinguished in the field from obvious features of land forms and their distribution. The position of some of the surficial deposits shown on figure 2 obviously is not in harmony with the topography of the base map. For example, the arcuate icecontact deposit (esker) in the eastern part of T.C., R. 2, as mapped by the writer, lies north of the eskerlike ridge shown in this area on the topographic map. Also, many swamp deposits, such as those near the central part of the quadrangle along Advent Brook and South Branch Whitney Brook and at the south end of the quadrangle along Larry Brook, irregularly cross topographic contours even though these swamps actually cover flat lowlands. At all places where the base map is incorrect, the surficial deposits are shown in their natural position and areal extent irrespective of topographic inconsistencies.

Glacial drift blankets the Bridgewater quadrangle in uneven but generally thin amounts. Vertical sections through the drift are available mostly in the eastern, agricultural part of the area, where pits have been dug at various places to obtain sand and gravel. Glacial drift can be observed in natural vertical sections in the western part of the quadrangle at fewer places, as in the steep banks of incised streams and at a few scattered sand and gravel pits. 


\section{GLACIAL DEPOSITS}

\section{UNDIFFERENTIATED DRIFT}

Undifferentiated drift as used herein includes (1) rudely stratified to well-stratified sand and pebbly gravel, commonly in a silty clay or sand matrix, and (2) rudely stratified to unstratified, poorly sorted till.

\section{TILI}

In general, till covers uplands, approximately above 700 feet, in the western part of the region (pl. 2). Typically, the till is poorly sorted, contains many boulders, and has a somewhat more clayey matrix than the modified stratified drift. Vertical sections of till were observed only in shallow holes where large trees had been uprooted by wind or in bulldozer cuts along tote roads. Till has a maximum thickness of about 40 feet, but is commonly thinner. It is absent, or merely a veneer about 1 foot thick, in many places on or near the tops of highlands, such as Nineteen Mountain in the northwest part of the quadrangle; at such places small outcrops of bedrock are common.

Till also makes certain characteristic land-form deposits. Till ridges similar in form to those described by Hanley (1959) are present at several places in the western part of the area. Normally these ridges are narrow, rounded at the ends, and have their long axes oriented S. $15^{\circ}$ E. to S. $25^{\circ}$ E. parallel with the regional trend of glacial striations and grooves (pl. 2). One drumlinlike, elongate hill is near the northwest corner of Cox Patent, another is about 3.5 miles west of Bridgewater, and a third is approximately 4.5 miles southwest of Bridgewater (pl. 2). The ridge west of Bridgewater has numerous bedrock exposures, and whether or not it is a drumlin, it has a bedrock core.

\section{OUTWASH}

Stratified sand and pebbly gravel, commonly with well-formed crossbedding, underlie most of the lowlands in the eastern part of the quadrangle and much of the land below 700 feet altitude in the western part. They are believed to be outwash. Typically, a complete vertical section through outwash consists, from top to bottom, of 1 to 3 feet of modified outwash (or till-like appearance), layered and crossbedded sand and pebbly gravel of different thicknesses at different places, and, wherever complete vertical sections are available (borrow pits 5, 6, and 14 in pl. 2), bedrock. Till has not been observed to underlie outwash anywhere in the quadrangle. Some of the stratified sand and pebbly gravel occurs in characteristic land forms, such as a pitted outwash plain in the northeastern part of the quadrangle and an outwash fan near Alerton Lake in the southcentral part of the map. Depressions in the pitted outwash plain, 
some of which are occupied by lakes, probably formed when ice blocks separated from the main ice sheet during the wasting of the glacier and became enclosed below, within, or on the outwash. When these ice blocks eventually melted, the outwash slumped or rimmed the sites. The outwash fan also contains local depressions formerly occupied by ice blocks. One of these is the small swamp between borrow pits 12 and 13 (pl. 2), which is surrounded by stratified and crossbedded sand and gravel.

\section{ICE-CONTACT DEPOSITS}

Stratified drift, although found mostly as outwash, occurs also in numerous ice-contact deposits. These deposits include ice-channel fillings such as the narrow and somewhat sinuous interrupted ridges (eskers) in the south-central part of the quadrangle (pl. 2). Isolated, small narrow ridges which may be crevasse fillings occur at and near sand and gravel pits 7, 9, and 10 and in the southwestern part of the quadrangle. Rudely to well-stratified sand and pebble and cobble gravel in a sandy and silty matrix characterize icechannel fillings. Such deposits may range in thickness from about 10 feet to a little more than 60 feet.

Sand and pebbly gravel that have rude to well-formed stratification also underlie the kame fields and associated kettles in the southcentral part of the map (pl. 2). The thickness of stratified drift in the kame fields ranges from slightly more than 60 feet at a few places to about 10 feet at other places. Where complete exposures through the kame fields are available, as in pits 15 and 16 (pl. 2), the drift rests directly on glacially smoothed bedrock.

Two conical hills in the northeastern part of the quadrangle, at sand and gravel pits 1-2 and 8 (pl. 2), have the form typical of kames and are composed of stratified sand and pebble and cobble gravel. The northernmost kame (pits 1 and 2, pl. 2) contains some contorted layers resembling slump features, which may have formed when a block of entrapped ice within the kame melted. The isolated occurrence of these two well formed kames, in contrast to the many small, subdued knobs in the region, suggests that they may have formed in a special way, perhaps as moulin kames. When last visited in August 1959, much of these deposits had been removed for local road building.

\section{POSTGLACIAL FEATURES MODIFIED STRATIFIED DRIFT}

Unstratified and poorly sorted drift is typically present within about 2 to 3 feet of the surface and looks like till. In all the sand and gravel pits in the quadrangle, however, stratified drift underlies this till-like drift and its layering can, in many places, be observed 
to extend irregularly into the unsorted, unstratified near-surface drift. In a few places, vague outlines of the layering of the subjacent drift can be traced through the near-surface, poorly sorted drift almost to the surface. The till-like drift is, therefore, modified stratified drift, formed through reworking of the original drift fabric by frost action, wedging by roots, and peridoic upturning of trees and their root systems since the stratified drift was deposited.

\section{SWAMP DEPOSITS}

Swamp deposits shown on plate 2 consist of muck and silt covered by a vegetal layer; they occupy flat lowlands which normally lack trees. They may overlie either till, outwash, or rest in part on bedrock. Typically, these swamps are located along streams or are drained by streams that commonly have beaver dams along their courses and at their downstream ends. Water in the streams is normally very sluggish, and such areas of arrested drainage are locally referred to as "deadwaters." Characteristically, the trees along the edge of such swamps are cedars, commonly mixed with small amounts of other conifers, such as spruce, hemlock, larch, or fir.

\section{STREAM PATTERNS}

Present-day stream patterns began to emerge following deglaciation. Preexisting drainage was modified at various places. For example, a preglacial valley bounded on its east and west sides by ridges of bedrock is about 2 miles west of Monticello Station in the south-central part of the area (pl. 2). Kame fields and an esker now occupy part of the valley and effectively block off the north end of it; the North Branch Meduxnekeag River has been thus diverted from a generally southerly direction of flow to an easterly one where it has encountered these deposits. Since the present drainage pattern became established, many of the streams have been incised through the drift down to bedrock (note outcrops along streams on pl. 2). The Prestile Stream, where it crosses the international boundary line in the northeast part of the quadrangle, occupies a V-shaped valley about 280 feet deep through a ridge composed of slate. The streams in the region have not attained their base level; they are characterized by rapidly flowing water and many minor rapids throughout their course. A small amount of incipient lateral planing at a few places along some major streams has produced minor stream terraces such as those along the North Branch Meduxnekeag River 2.3 miles west of Monticello and approximately 1 mile southeast of it.

Alluvium is confined to the stream beds and consists mostly of reworked drift boulders. At some places where the stream has cut down to bedrock, the alluvium may locally contain numerous boulders and pebbles of the bedrock. 


\section{WEATHERING PROFILE}

A shallow weathered profile, presumably formed in postglacial time, is present in the upper part of all the drift. Typically it consists of three zones, separated by gradational boundaries, which from top to bottom are (1) buff to brown loamy to stony soil and roots, abut 0.5 to 1 foot thick, (2) brown to reddish-brown silty and sandy clay approximately 1 to 2 feet thick that encloses weathered, punky rock fragments, and (3) gray gravel and sand, about 1 to 2 feet thick, that has minor iron stains and weathered rock fragments which grade imperceptibly down into unweathered drift. Zones 1 and 2 and the upper part of 3 are modified drift (p. 45). At a few places, such as at pits 4 and 14 (pl. 2), little or no weathered drift is present, but a stony soil about 6 inches thick is underlain by fresh, gray sand and pebble gravel. Commonly the soil in the cultivated areas is stony, but where the underlying drift is mainly silt and sand the soil may locally be relatively free of stones.

\section{SUMMARY OF GLACIAL AND POSTGLACIAL EVENTS}

Glacially polished outcrops (some etched with grooves and striations), the mantle of till, and the widespread distribution of icecontact deposits clearly indicate that all of the Bridgewater quadrangle was at one time covered by an extensive ice sheet. Apparently very little plucking was done by the ice; rather, it appears mostly to have shaped and smoothed preglacial topography. Any preglacial soils or surficial deposits that may have been present were undoubtedly scraped away by the ice sheet. Certainly, none has been found in the sand and gravel pits that expose complete vertical sections through the drift. A thin blanket of till may have been deposited by the ice over the entire region, but till has not been recognized in the lowlands of the eastern part of the quadrangle and presumably was removed from there before glacial outwash was deposited.

Local stagnation of thin ice may have occurred at different places as the ice sheet retreated. The esker and the small kames in the south-central part of the quadrangle could not have formed and been preserved in ice that was actively moving.

As the glacier retreated, it not only thinned but apparently also wasted by having blocks of ice become detached from the main mass. Such ice blocks eventually were covered or enclosed by outwash and when they melted small depressions were formed. Sand and gravel pit exposures indicate that glaciofluvial reworking and removal of till in lowland areas was quite thorough at this stage of deglaciation in the eastern part of the area, because all till has been removed and only outwash, resting directly on bedrock, is present. Till is present, however, on many slopes and tops of hills in this 
region. Possibly glaciofluvial erosion of till was also active under parts of the ice sheet in the central part of the region, inasmuch as stratified drift in the kames at sand and gravel pits 15 and 16 (pl. 2) also rests directly on glacially polished bedrock. Alternatively, these places may have had the till removed by proglacial action or perhaps till was never deposited there.

Characteristically, drift covering the Bridgewater quadrangle has a shallow, poorly formed weathering profile in which the character of the original material of the drift is readily identifiable. Such relatively fresh drift is typical of Wisconsin drift deposited elsewhere in North America. Pollen studies by Deevey (1951) of stratigraphic sections from three lakes and one bog in Aroostook County, Maine (about 20 miles northwest of the Bridgewater quadrangle), suggest a sequence of climatic events similar to those of Scandinavia. Near the base, the Aroostook sections have a pollen horizon of Alleröd character above a tundra horizon, which in turn rests on drift. If Deevy is correct, and if the most recent dates for the end of the Alleröd are accepted (Tauber, 1960a, b), the Bridgewater quadrangle and nearby areas were deglaciated more than 11,000 years ago.

\section{STRUCTURAL GEOLOGY}

Layered rocks in the Bridgewater quadrangle are highly folded, some units more so than others. Although the stratigraphy recognized in the area permits defining of gross anticlinal and synclinal structures, the recognition of smaller folds and faults is more difficult because of the absence of distinctive marker beds. Nonetheless such smaller folds are abundant and characterize the regional style of deformation.

\section{ForDs}

Because of the limited stratigraphic control available, most folds mapped in the Bridgewater quadrangle are based on structural features such as the attitude and top-facing direction of bedding. Known top-facing directions in bedding are not abundant, however, and consequently only the trend of bedding. and its dip direction frequently have been used to outline folds, especially in terranes with little contrast in lithology such as areas underlain by ribbon rock of the Meduxnekeag Formation. The shapes of the folds on plate 1 are somewhat generalized. Smooth rounded noses and relatively uncontorted limbs are shown wherever information was insufficient to determine the amount of crenulation, if any, that may be present.

Throughout the region, the dips of layered rocks are steep or vertical, except for parts of the Bell Brook Formation in the south- 
west corner of the Bridgewater quadrangle. Here the conglomerate member, being a competent unit, is only gently folded, and dips from a few degrees to about $30^{\circ}$ are typical of exposures along Howard Brook (pl. 1). The conglomerate member also acted as a stiffening horizon for the less competent rocks of the slate member of the Bell Brook Formation which overlie it in this area. Thus, slate of this unit to the north of the conglomerate member along South Brook have gentle or moderate dips in contrast to the rocks of the slate member elsewhere in the region which have steep or vertical dips (pl. 1).

The geometry of the folds in many of the incompetent rocks of the region is complex. Reversals in the plunge of folds are common and may occur over short distances along the trend of a fold. An example occurs in the slate lens of the ribbon rock member on the hill immediately north of the elevation 539 feet, along Ames Road in the northeast part of Monticello Township (pl. 1).

At a few places the axial portion of folds appear to be inverted and plunge directions are overturned. This feature can be seen at the road-metal quarry on the west side of U.S. Highway 1, about 1.6 miles north of Jewells Corner in the north-central part of Monticello Township (pl. 1, no. 11). Here, ribbon rock occurs as part of the northeast end of an antiformal ${ }^{5}$ flexure that plunges steeply northeast and is broken by a minor fault (fig. 8). The beds of the northeast limb of the antiform dip $70^{\circ}$ or more toward the east, but graded bedding in some of the ribbon rock at different places along this limb indicates that tops of the beds face westward and that the beds are overturned. Similar overturning is present near the nose of the fold but at the hinge area, mullion structure apparently has obscured any graded bedding that may have been present. Nonetheless, it is clear that, although the axial portion of the fold exposed in this quarry is structurally an antiform, in reality it is a part of the axial portion of a stratigraphic syncline with an inverted plunge. Similar examples of inversion of plunge near the nose of folds have been recognized in the Maple-Hovey manganese deposit west of here (Pavlides, 1962, p. 45 and pl. 2).

Two culminations separated by a depression are present along the southeast flank of the anticline that trends approximately parallel with the North Branch Meduxnekeag River in the west-central part of the quadrangle. Aside from these, the only other flexures that appear to be athwart the regional trend of the major folds are the

\footnotetext{
5 "Antiform" is used here as a descriptive term for an upfold or structural anticline. "Synform" is a similar term for a downfold or structural syncline. Thus, an antiform may be a stratigraphic anticline or an overturned stratigraphic syncline. Similarly, a synform may be a stratigraphic syncline or an inverted stratigraphic anticline.
} 


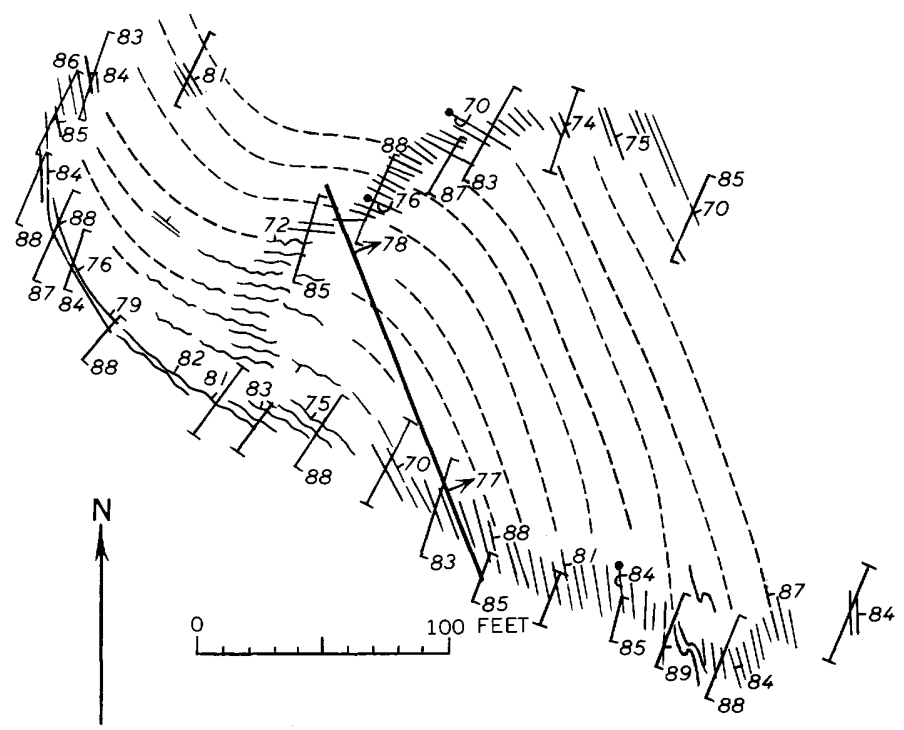

EXPLANATION

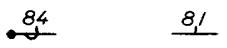

Strike and dip of bedding Dot indicates top facing direction, determined from sedimentary structures

Inferred trend of bedding

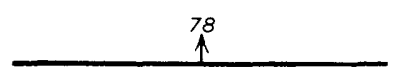

Fault, showing dip
85

Strike and dip of cleavage

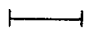

Strike of vertical cleavage

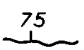

Mullion structure

Showing dip of surface

\section{Drag fold}

FIGURE 8.-Geologic sketch map of the road-metal quarry along U.S. Highway 1, Monticello Township, Maine. (Mapped by Louis Pavlides and W. S. White, 1949, and modified by Pavlides.)

small northwest-trending cross folds about 1.5 miles northwest of Monticello (pl. 1).

A marked feature of the folds in the Bridgewater quadrangle is their change in trend directions. In the northern part of the quadrangle, the folds trend in a north to northeast direction. In the central and southwestern parts of the quadrangle some of the folds trend northwest (pl. 1). Apparently the fold axes are sinuously warped from a northeasterly trend through a northerly trend and into a northwesterly trend in progressing from north to south across the quadrangle. In the northern parts of the Houlton quadrangle (immediately south of the Bridgewater quadrangle), fold axes change trend from northwest, to north, to northeast and eventually, in the central part of this quadrangle, to an almost due west trend. 
Hence, the trend of the folds in the Bridgewater and Houlton quadrangles forms a large sigmoidal flexure (Pavlides and others, 1964, fig. 1, p. C30).

In addition to the larger folds of the region, there are many minor folds that have a wavelength of a few feet or less. These are shown schematically in plate 1. Minor folds are generally restricted to the ribbon rock member of the Meduxnekeag Formation. They are characterized by steep plunges that rarely are less than $60^{\circ}$ and more commonly are nearly vertical. Nearly all these folds appear to be formed along the strike direction rather than along the dip direction of bedding; drag folds or related flexures in vertical bedrock exposures are absent or rare. Such exposures admittedly are few in number; they are available in some roadcuts and in the road-metal quarry near Monticello.

Minor folds include normal anticlinal and synclinal flexures and sinistral and dextral folds. The anticlinal and synclinal folds at the axial part of plunging folds may be relatively smooth flexures or they may be highly crumpled or even sheared owing to differential slip along cleavage. Sinistral and dextral folds, which probably are drag folds along the limbs of larger folds, more commonly are smooth flexures rather than broken by slip cleavage.

Some shear folds are also present, however; they were formed by slight differential movements along closely spaced cleavage planes that transect bedding at a large angle (fig. 9).

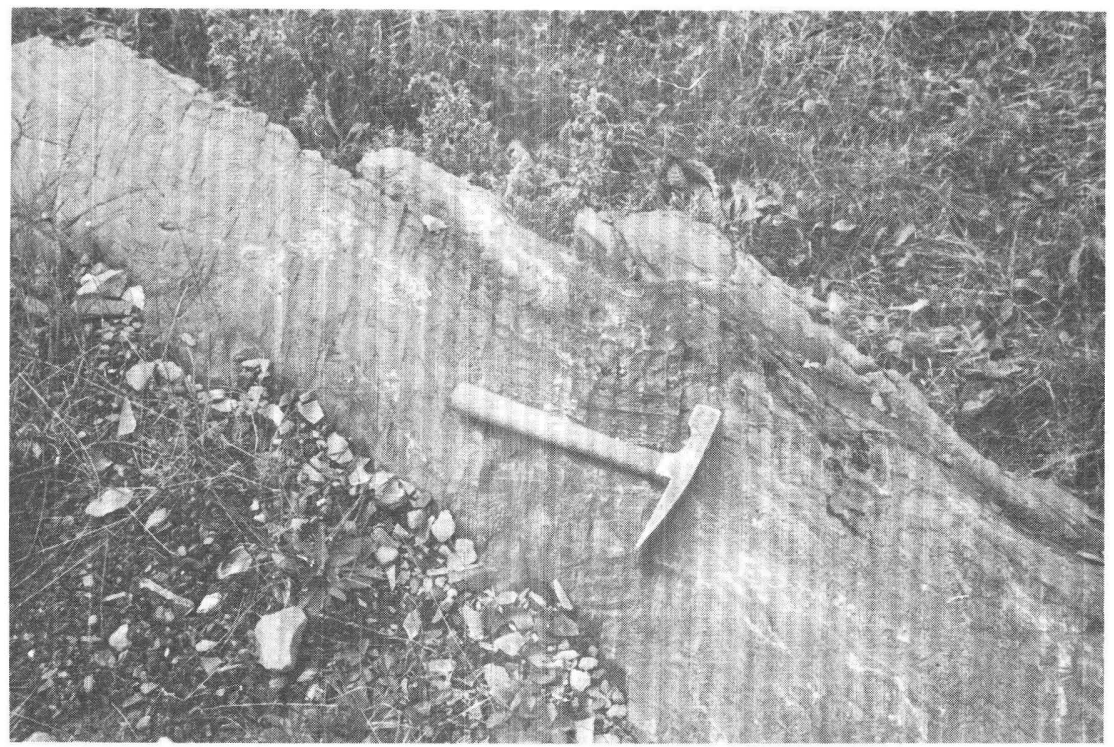

Figure 9.-Small shear fold formed by differential slip of rock slices along cleavage planes. Sinistral pattern of this shear fold corresponds to the sinistral drag fold a few feet away from it. 


\section{CLEAVAGE}

Well-formed, steeply dipping or vertical fracture cleavage is commonly present in many of the sedimentary and in some of the volcanic rocks of the Bridgewater quadrangle. Fracture cleavage is used in this report purely as a descriptive term. It is a secondary structure consisting of planes of parting that are commonly spaced less than a few inches apart and, generally, only a small fraction of a millimeter apart.

Such parting planes are fractures that generally cut across the plane in which platy minerals lie in layered rocks in most folds. However, they may be parallel to platy minerals on the limbs of some isoclinal folds, although they cut across planes in which the platy minerals lie at the fold axes.

Fracture cleavage apparently formed as a late structural feature in the region, after the rocks had been folded. It parallels the axes of many northeast-trending folds or cuts across their axes at a small angle (pl. 1). North- and northwest-trending fold axes are transected at a greater angle by cleavage. Many fold axes are curved or sinuous and in such folds the cleavage may parallel the fold axes at one place along the fold and cut across it at different angles at other places.

Commonly, small-scale movement along fracture cleavage planes has offset bedding and either accentuated existing flexures or formed shear folds on a small scale. Such slip movement in some places is readily visible in outcrop (fig. 9). Slip along cleavage at other places is incipient and can be seen only in thin section (fig. 10). It is also apparent in thin sections, both of cleaved and of uncleaved rocks, that the micas mostly lie in planes parallel to bedding (fig. 10). Some of the micas in the cleaved rocks have been rotated by slip movements along cleavages and dragged into crude chevron patterns. A subordinate amount of mica is also alined in the cleavage planes, but mostly the cleavage planes are closely spaced fractures containing a dark film of unidentifiable matter.

Cleavage is present in all the sedimentary units of the region except the conglomerate member of the Bell Brook Formation (pl. 1). This unit consists of heavy bedded rocks that apparently were too brittle to develop cleavage. For similar reasons, cleavage is absent in heavy bedded layers that occur at various places in most of the other sedimentary units. It commonly is present, however, in sandy beds less than a few feet thick that occur as interbeds in dominately slaty rocks. Cleavage is refracted and is more widely spaced in such sandy interbeds than is the slaty cleavage of the enclosing rocks. At the noses of minor folds it is normally refracted into a 
cleavage fan (fig. 11A), which is confined entirely to the thin sandy layers.

Cleavage refraction also occurs within layers having graded bedding; the grading in grain size may be visible megascopically or only in thin section. This type of refracted cleavage characteristically intersects bedding at a rather large angle in the coarser part of the graded bed and at progressively more acute angles in the finer grained parts. The result is a series of parallel curved fractures (fig. 12A) that in casual observation may be mistaken for crossbedding. Sigmoidally curved cleavage is a rare type of cleavage that is present at only a few places (fig. 12B). It is believed to have formed from an originally planar cleavage that was rotated by differential shear of a bed enclosed by more competent layers. If such differential slip occurs only along one side of a layer, it may form an intrastratally refracted cleavage outwardly similar to that caused by graded bedding.

Cleavage cracks are filled by calcite at some places; less commonly, argillaceous matter apparently has been injected from the structurally underlying slate layers into the cleavage cracks of the more brittle sandier beds. This filling has produced a cleavage banding at a few places that closely resembles sedimentary layering.

Differential slip movement along fracture cleavage planes also has locally sheared and disrupted many small folds (fig. 11B). Sandy layers, at a few places, have been sliced into cleavage mullions (fig. $11 C)$.

Vertical to nearly vertical fracture cleavage spaced 1 to 2 inches apart and trending $\mathrm{N} .80^{\circ} \mathrm{W}$. or due west is rare and occurs only at a few places. Commonly, it offsets the regional northeast-trending fracture cleavage a few millimeters and rudely plicates it into smallscale chevrons.

\section{LINEATION}

The most pronounced regional lineation in the Bridgewater quadrangle is the trend of the fold axes of the larger folds; a similar, smaller scale lineation is formed by axes of minor folds (pl. 1).

Most conspicuous of all lineations in the region on an outcrop scale, however, is that resulting from the intersections of bedding and cleavage planes. This lineation is particularly apparent on cleavage planes, where the bedding appears as fine lines or bands; its plunge is generally steep to vertical. Bedding-cleavage intersection lineation is shown at a few places in plate 1 and only where the cleavage is vertical.

Mullion structure is another form of lineation in the area. Cleavage mullions involve differential slip of the corrugated noses of folds 


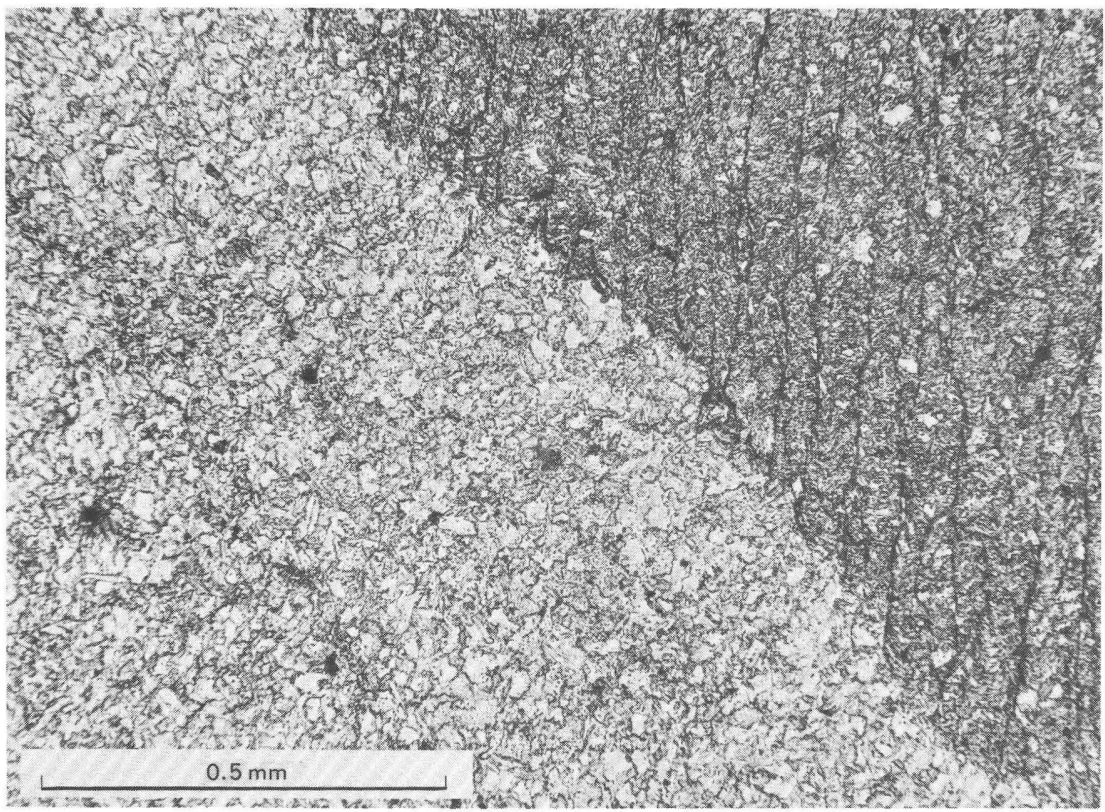

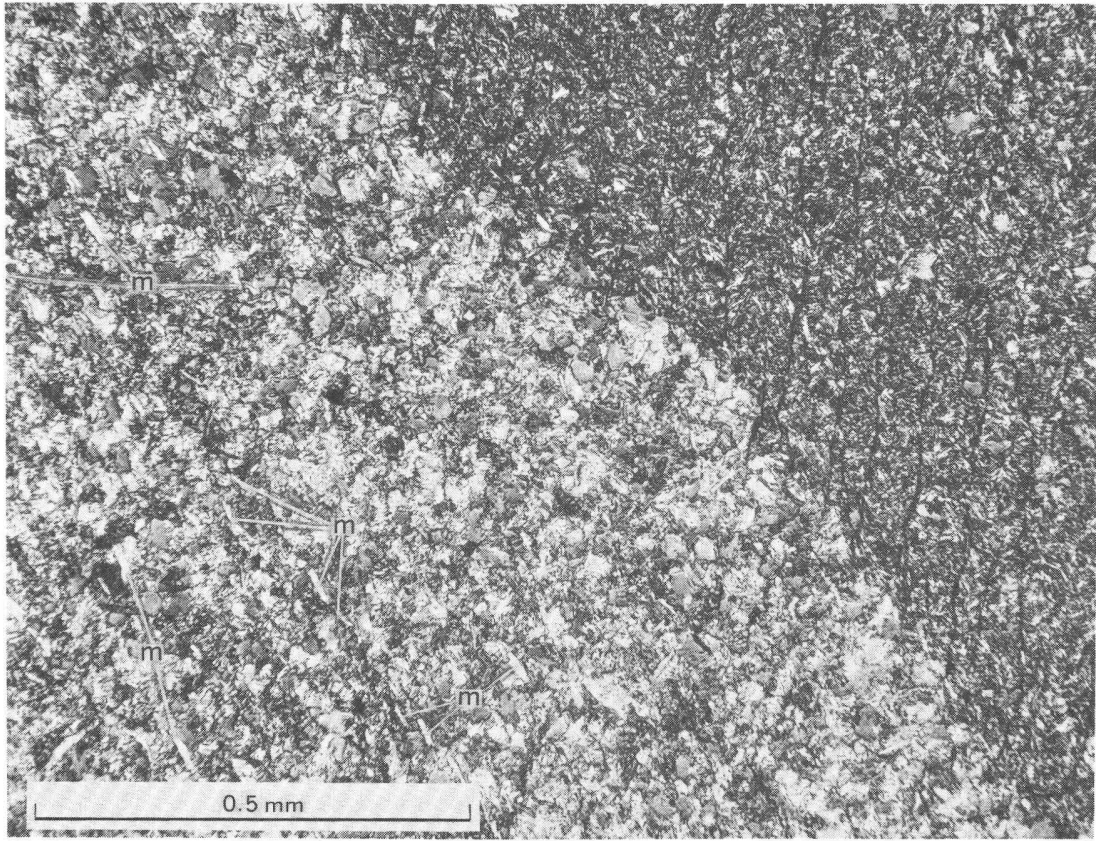

\section{$B$}

Figure 10.-Incipient slip cleavage. 
(fig. 11C). Mullions having the form simply of grooves and corrugations near the axial portion of folds are also prevalent. Pencil lineation, characterized by pencillike to rulerlike rock slivers, has formed (fig. 13) at a few places where cleavage and bedding intersect at a large angle.

Lineation in the form of gently dipping to subhorizontal bands 1 to 3 inches wide are present in a few steep or vertical exposures (fig. 14). Typically, these lineation bands result from a slight offset of a steeply dipping or vertical planar surface, such as bedding. The band in which slight offset takes place has a slightly gentler dip than does the planar surface it transects. Consequently, it reflects light differently and is thus made noticeable, generally as a band striking across the planar surface. The origin of this lineation is not clear; it may result from differential movement along subhorizontal or gently dipping incipient shear zones. A similar feature on cleavage surfaces in the western Appalachians of southern Quebec has been described as "knick fold layers" (Eakins, 1962, p. 84 and 88 ).

Lineation resulting from mineral alinement is rare. Normally, in micaceous impure quartzitic rocks, mica flakes are arranged with their platy surfaces in the plane of bedding, but the long axes of the mica plates are not alined in any particular direction. Mineral orientation that has been noted results from growth of new minerals. Notable of such lineation is the pressure-shadow growths of quartz in the plane of cleavage along the sides of pyrite crystals (fig. 15).

Elongate lithic clasts alined in the plane of cleavage are evident in some of the volcanic conglomerate and breccia on Nineteen Mountain in the northwest part of the Bridgewater quadrangle (pl. 1). Because such exposures are mostly pavement outcrops, only a two-dimensional view of the alined clasts is visible and their shape down dip in the cleavage direction is not known.

Boudinage occurs incipiently only at a few places in quartzitic beds enclosed by slate in the Meduxnekeag Formation.

\section{JOINTS}

Joints are best formed in competent rocks such as quartzite, greenstone, or garnet porphyry.

The principal strike directions of these joints are northwest, northeast, and east. Dips are generally vertical or steep.

\section{EXPLANATION OF FIGURE 10}

$A$, Incipient slip cleavage formed in slate layer that does not extend into quartzose carbonate layer; plane-polarized light. $B$, Same as $A$, but under crossed nicols. Note alinement of mica flakes $(\mathrm{m})$ parallel with bedding. Similarly alined mica flakes in the slate layer have been locally rotated into crude chevron patterns between the slip cleavage planes. 

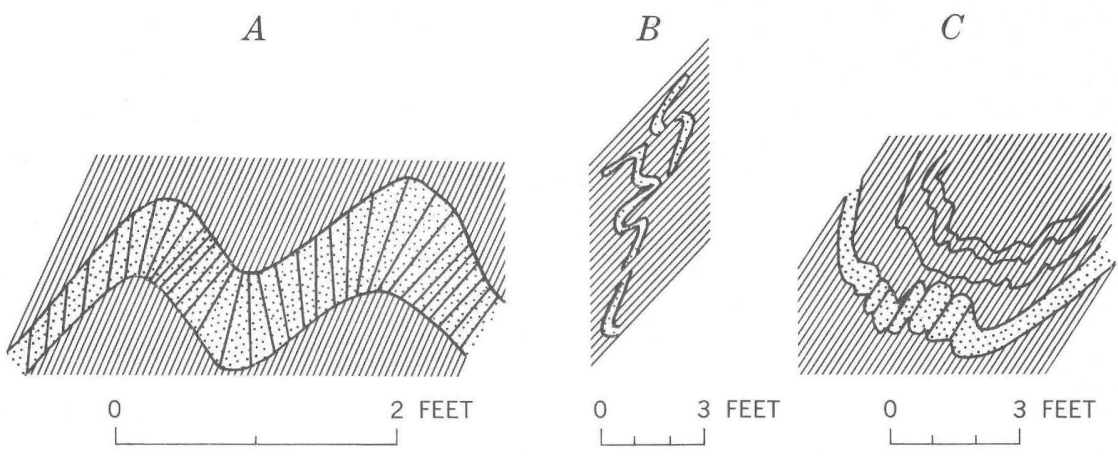

FIGURE 11.-Horizontal view of generalized sketches of fracture cleavage and fold relationships in ribbon rock of the Meduxnekeag Formation. Stippled pattern is of quartzose limestone; closely ruled pattern is slate. All folds have essentially vertical plunges. $A$, Fan cleavage formed in quartzose limestone layers enclosed by slate. $B$, Small folds sheared and disrupted by differential slip along fracture cleavage. $C$, Cleavage mullions formed in quartzose limestone layer by differential slip along fracture cleavage.

A

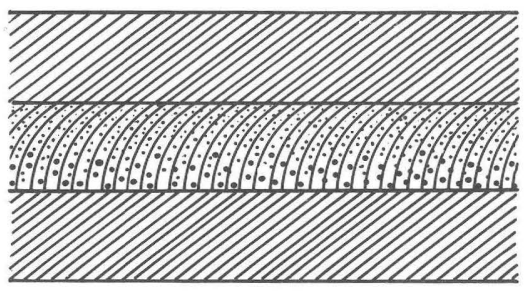

$B$

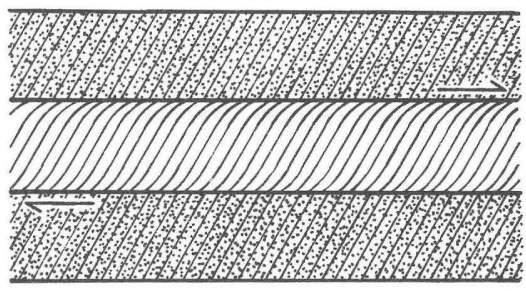

FIGURE 12.-Schematic diagrams of intrastratally refracted cleavage. $A, \operatorname{Re}-$ fracted cleavage in a graded sandstone enclosed in slate. $B$, Sigmoidal cleavage in an incompetent layer; formed by slip along bedding planes of the enclosing, more competent rocks.

Joints are not well formed in incompetent rocks, such as much of the Meduxnekeag Formation or the slate member of the Bell Brook Formation. At a few places, gently dipping tension joints cut across mullion structure or occur in thin competent beds enclosed between less competent beds (fig. 16).

\section{FAULTS}

Faults are difficult to recognize in the Bridgewater quadrangle. Those that have been mapped generally strike northeast or north. The movement directions along these faults is not known.

Regional aeromagnetic data can be interpreted to suggest the presence of a low-angle fault in the subsurface of the western part of the Bridgewater quadrangle. The gentle east-sloping magnetic 


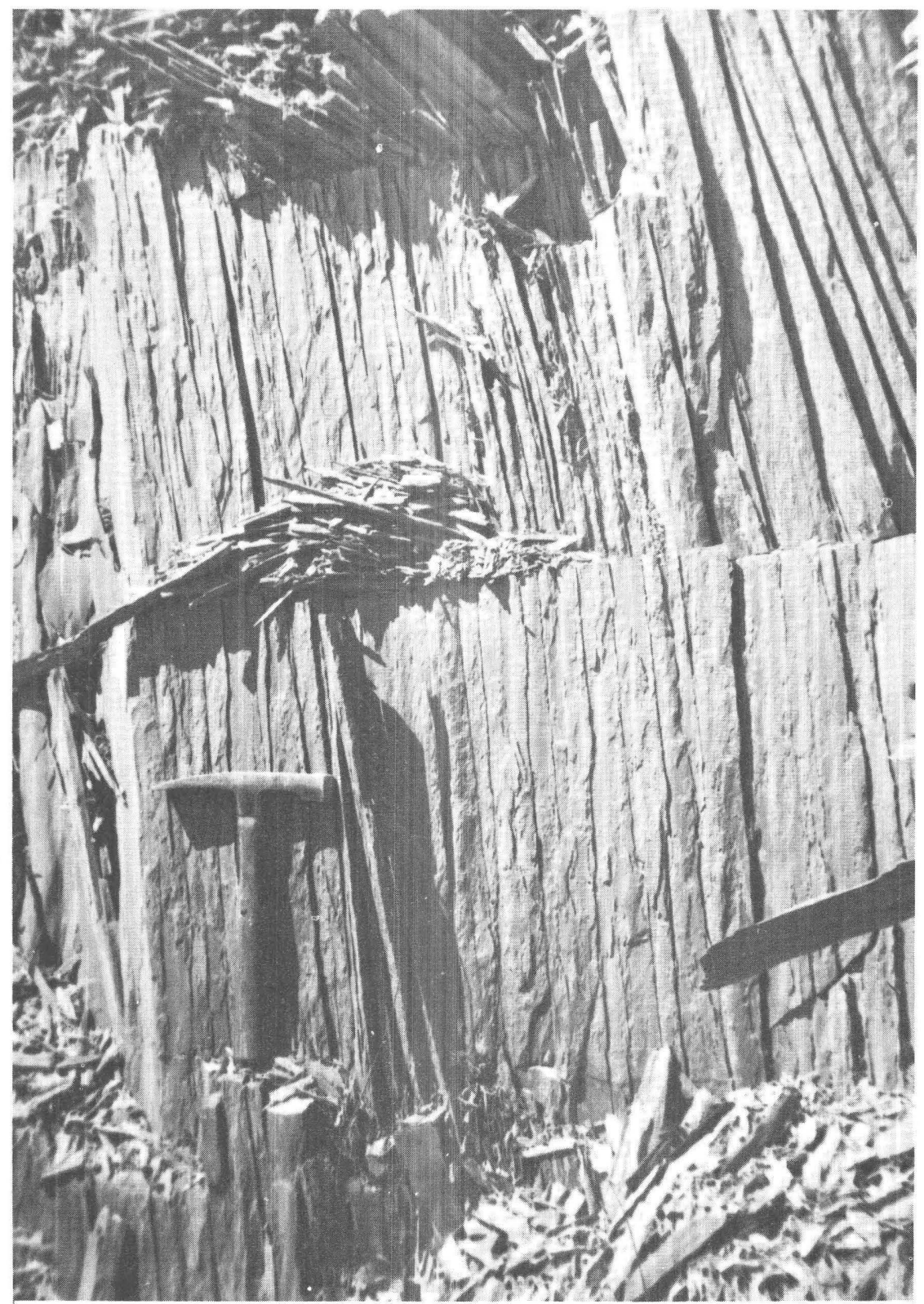

FigUre 13.-Pencil lineation in calcareous rocks of the Meduxnekeag Formation. Exposure is in roadcut along U.S. Highway 1.

gradient along the west side of the quadrangle (pl. 3) actually extends westward into the Howe Brook quadrangle and merges with a large anomalous magnetic pattern that covers a mass of volcanic rocks of the Dunn Brook Formation. Griscom's analysis of this magnetic feature (see p. 66) suggests that the volcanic rocks (Dunn 


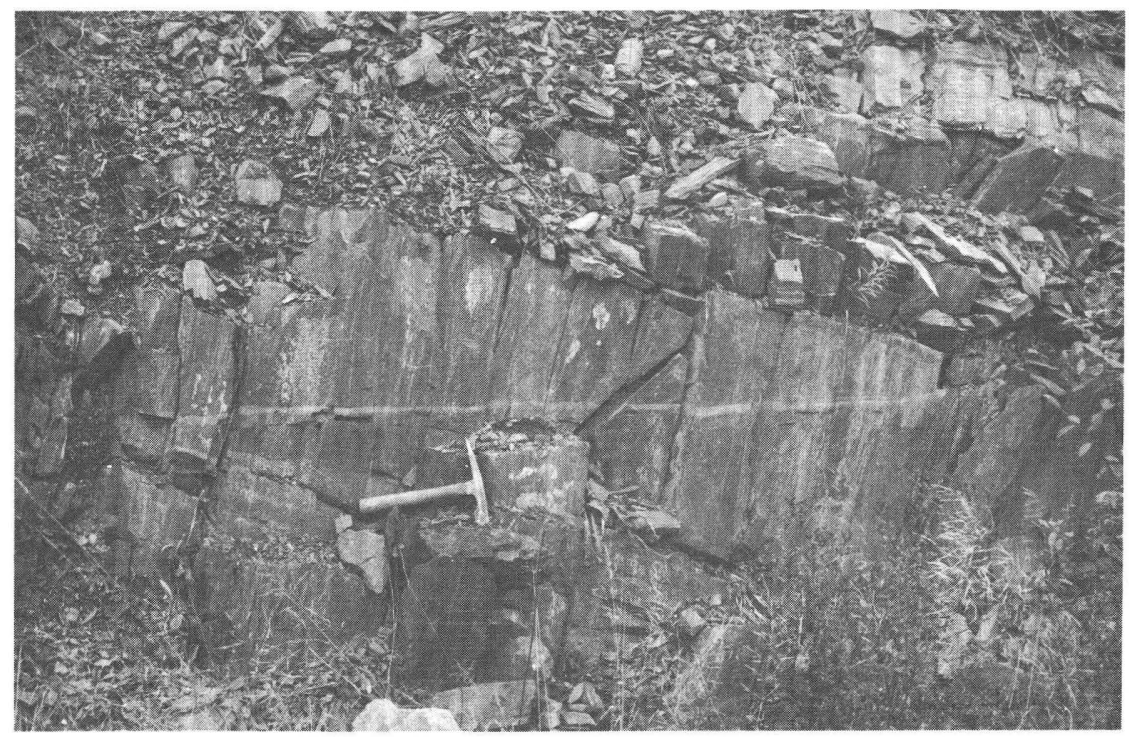

FIG URE 14.-Lineation band in nearly vertical exposure of slaty calcareous rock of the Meduxnekeag Formation. One-inch-wide lineation band in horizontal attitude immediately above hammer point strikes across the face of almost vertical bedding cut by fracture cleavage that dips steeply to the left. Exposure occurs along U.S. Highway 1.

Brook Formation) extend to the east beneath the Meduxnekeag Formation and that the surface of the volcanic rocks probably dips about $20^{\circ}$ to the southeast. If the Dunn Brook Formation is younger than the Meduxnekeag Formation (Middle to Upper(?) Ordovician), then the surface separating the volcanic rocks of the Dunn Brook Formation from the overlying rocks is a thrust fault and the rocks on the east are the overriding rocks. The uncertain age of the Dunn Brook Formation makes this interpretation a speculation at this time. It is known, however, that Silurian rocks occur at the top of the Dunn Brook, but they do not necessarily date the formation. If the Dunn Brook actually is considerably older than Silurian (possibly equivalent to the Early Ordovician Shin Brook Formation to the southwest (Neuman, 1964)), then the thrust fault interpretation is not necessarily valid.

\section{METAMORPHISM}

\section{REGIONAL METAMORPHISM}

Greenschist facies regional metamorphism has affected most of the rocks of the Bridgewater quadrangle. Greenstone, such as is found in small dikes or in the Spruce Top Greenstone (pl. 1) generally is the most modified by regional metamorphism. The modal analyses of greenstone in table 3 are typical of the assemblage nor- 


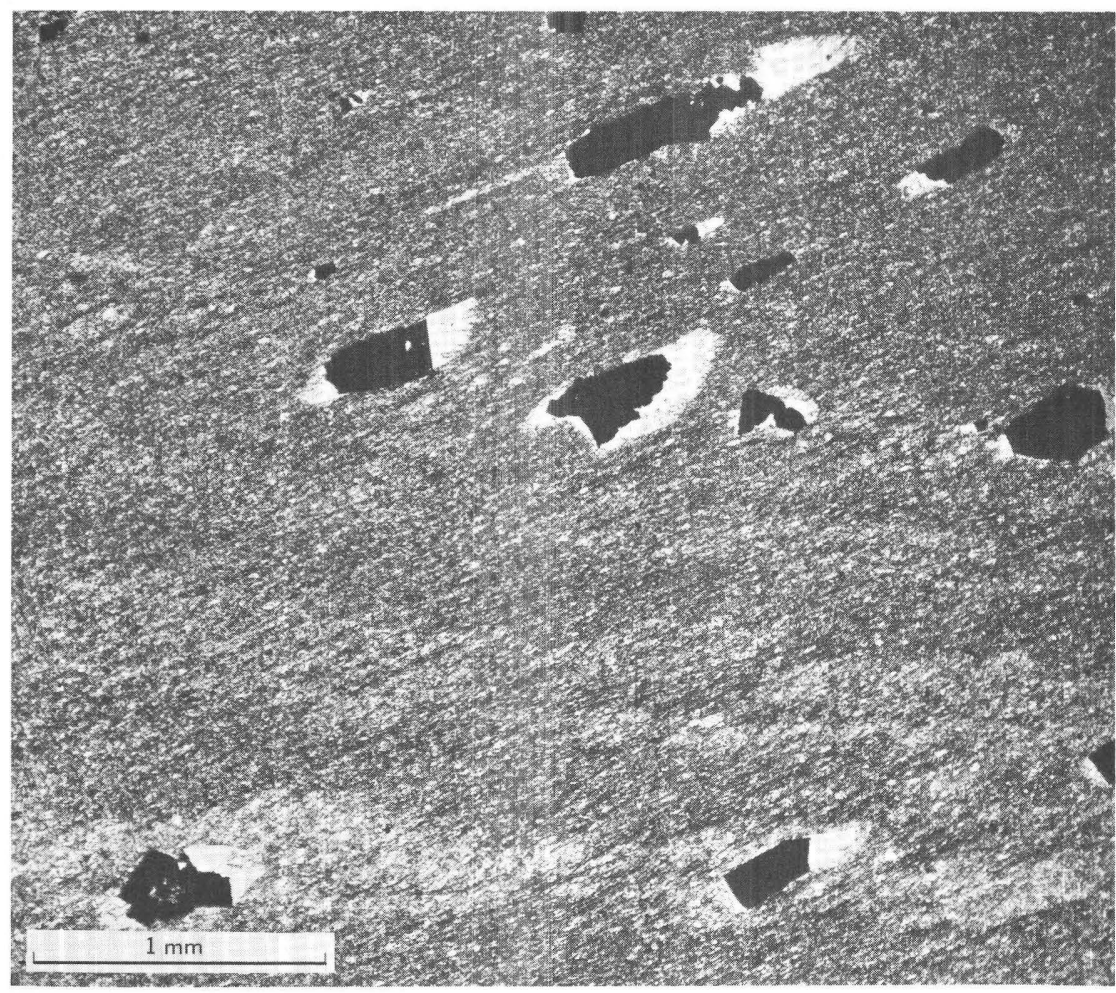

FIgURE 15.-Photomicrograph of feathery quartz growths at the ends of pyrite crystals in calcareous slate. Pyrite occurs mostly along bedding, whereas quartz growths have formed in the cleavage plane. Pyrite crystals in photograph have long dimensions alined in cleavage plane although elsewhere in the slide cubic crystals are also present. Ordinary light.

mally found in the greenschist facies. Regional metamorphism of the greenstone in the Bridgewater quadrangle and the adjoining Howe Brook quadrangle to the west has been previously described (Pavlides, 1962, p. 32-33). It is not clear whether the albite of some of the greenstone formed through regional metamorphism or as a pyrogenic or even deuteric mineral. The fact that the greenstone from Collins Ridge, for example, contains albite ophitically enclosed in pyroxene (Pavlides, 1962, fig. 12) suggests that the albite here is possibly primary. Some minerals in the greenstone are definitely of metamorphic origin. Actinolite is commonly peripheral to some pyroxene crystals or occurs in the groundmass. Stilpnomelane is more common in the small greenstone dikes of the area than in the greenstone of the Spruce Top Formation. The small amount of prehnite in the greenstone from Collins Ridge (Nos. 1, 2, table 5) occurs mostly in veinlets and less commonly in vesicles; prehnite has not been recognized in the groundmass of the greenstone. Hence, it 


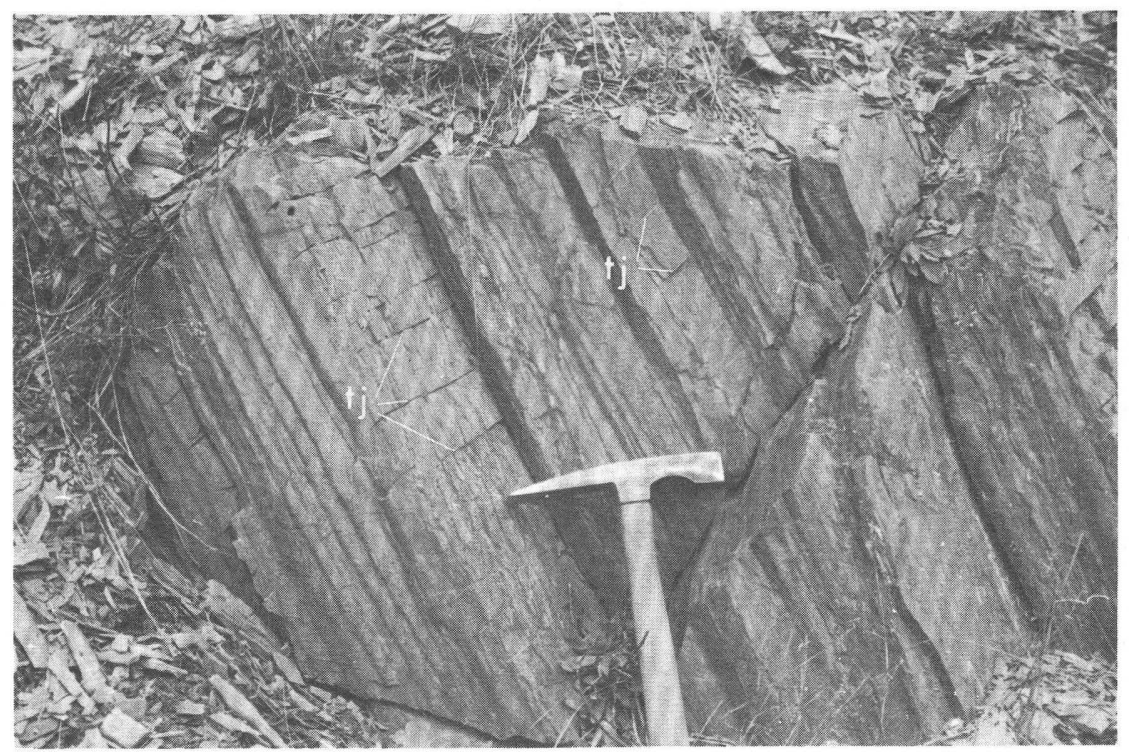

FIGURE 16.-Tension joints (tj) in steeply dipping quartzose limestone layer enclosed between less brittle limy beds of the Meduxnekeag Formation.

is difficult to determine whether prehnite represents a local lower grade zeolite facies of metamorphism or whether it is an original mineral of the rocks.

Chlorite is the chief metamorphic mineral in the volcanic rocks of the Dunn Brook Formation. Commonly these rocks have a slaty cleavage that is absent in the associated, but more competent, greenstone of the Spruce Top Greenstone.

Mineral changes induced by regional metamorphism in the metasedimentary rocks of the area are not very marked. Chiefly the changes are indicated by chlorite and muscovite which occur as fine-grained flakes that are at least several times the size of the more finely divided muscovite (sericite) and chlorite that comprise the bulk of the micaceous matter in the matrix of the slate and the other clastic rocks. Carbonate also has undergone some local textural modification; carbonate "porphyroblasts," several times the size of the carbonate in the matrix are visible in thin section in some of the carbonate rocks. The pressure shadow growths that bound some opaque minerals (fig. 15) also probably formed at some stage of the regional metamorphism of these rocks. In general, therefore, the detrital rocks of the area are normally characterized by a regional metamorphic mineral assemblage no higher than the chlorite zone.

Usually, greenschist facies metamorphism is considered to take place at a temperature of about $400^{\circ} \mathrm{C}$, or roughly under a stratigraphic load of about 40,000 feet. The low-grade limit is about 
$300^{\circ} \mathrm{C}$, which corresponds to about 30,000 feet of burial (Fyfe, Turner, and Verhoogen, 1958, p. 173). The low-grade to moderate greenschist mineral assemblages present in the regionally metamorphosed rocks of the Bridgewater quadrangle indicate that metamorphism here possibly took place under 30,000 to 40,000 feet of rock. The estimated aggregate thickness of the stratigraphic units in the Bridgewater quadrangle (table 1) is, in general, consistent with this supposition.

The dacite-diorite dike and its associated rhyolitic rocks on Sugar Loaf and the garnet porphyry do not show any evidence of regional metamorphism and are believed to have been emplaced after metamorphism. These rocks, particularly in the small garnet porphyry plutons and the dacite-diorite dike, have highly sericitized feldspar and chloritized biotite and garnet that probably resulted from a latestage hydrothermal alteration. The chloritization of the biotite and some of the garnet in these rocks is considered to be a result of a late-stage retrogressive metamorphism possibly associated with the sericitic alteration of the associated feldspar.

\section{CONTACT METAMORPHISM}

The dike of dacite-diorite and the two small plutons of garnet porphyry have baked, or thermally metamorphosed, some of the sedimentary rocks that they have intruded (pl. 1). Consequently, thin zones, generally ranging from a few hundred feet to about 1,500 feet in width, bound the contacts of these intrusions at most places. The contacts of these intrusions appear to be very steep or nearly vertical. The border zones of baked rocks, therefore, may approximately represent the actual extent of thermal metamorphism outward from the intrusions.

Although zones of hornfels surround the intrusions that have been emplaced in ribbon rock of the Meduxnekeag Formation, such zones are either absent or of restricted extent where the intrusions have invaded noncalcareous slate. Thus, the pluton on Estabrook Hill, emplaced entirely in ribbon rock, seems to have a complete aureole of hornfels. However, only minor amounts of hornfels, and of a different type (see below), are associated with the smaller pluton to the southwest that is emplaced in the noncalcareous slate member of the Meduxnekeag Formation. Similarly, the dacite-diorite dike is bounded by well-formed zones of hornfels where it cuts ribbon rock, but it has not caused any visible thermal metamorphism in the noncalcareous slates that it has intruded at its south end (pl. 1).

\section{TREMOLITE-DIOPSDDE HORNFELS}

Thermally metamorphosed ribbon rock, the most abundant hornfels, characteristically is a very fine grained dense flinty rock in 
which original sedimentary layering and lamination are well preserved. A few layers are nearly porcelaneous. Slaty cleavage, normally present in ribbon rock, is locally obliterated in some of the hornfels. The characteristic medium bluish gray of ribbon rock is also changed; different tones of grayish pink or pale red are interlayered with light-gray or nearly black layers. Some rocks have been converted completely to light-gray or dark-gray hornfels.

The minerals in this fine-grained hornfels are difficult to identify. Thin-section examination and X-ray analyses of bulk rock samples indicate that many of these rocks contain tremolite or diopside or both. The diopside mostly occurs as small granular aggregates, which commonly extinguish in thin section as crudely tabular or elongate grains. In general, the long dimension of both the tremolite and the "aggregate grains" of diopside is parallel with the original layering of the ribbon rock.

\section{BIOTITE-GARNET HORNFELS}

Finely granular spotted hornfels crops out at the west end of the garnet porphyry exposed along the North Branch Meduxnekeag River and occurs chiefly as small xenoliths within the porphyry on Estabrook Hill. The spotted hornfels associated with the smaller pluton has been described by Pavlides (1962, p. 33) as:

*** a finely granular gray-green rock. Some rocks have a distinct purplish cast but in others this color is barely perceptible. Small round spots, normally of a dark dull-purplish color, are a common megascopic feature. Small grains of porphyroblastic garnets and aggregates of garnet are chiefly responsible for the spotted appearance of the rock.

Thin sections show spotted hornfels consists of rounded to angular quartz grains, small amounts of feldspar, and fine grains of muscovite and reddishbrown biotite. Some of the quartz grains contain small flakes of biotite as inclusions. Large poikilitic garnets containing inclusions of biotite and quartz form conspicuous porphyroblasts. The garnet porphyroblasts normally have dodecahedral outlines but some garnet occurs in subhedral to anhedral habit in subspherical knots or clusters. The garnet is commonly highly fractured and its fractures are generally filled by muscovite. Other minerals are also present as fracture-filling constituents, but these are too fine-grained and ill-defined to be resolved in thin section.

Biotite and muscovite, in some of the spotted hornfels, have a decussate groundmass structure. In such rocks small garnets are intimately associated with reddish-brown biotite and quartz in small knots and clusters. A small amount of green biotite is present in one such garnetiferous knot. Much of the reddish-brown biotite has finely granular aggregates resembling leucoxenecoated sphene along cleavage. Randomly distributed rutilelike needles are common inclusions in reddish-brown biotite. In some garnetiferous clusters, biotite has altered to penninite(?) and to muscovite in places.

Spotted hornfels xenoliths, in the garnet porphyry pluton on Estabrook Hill, usually are petrographically similar to those described above. An additional feature of this spotted hornfels is 
the rather sugary, uniform size of the quartz grains that normally contain small inclusions, the most common of which are flakes of biotite (fig. 17). Some of these poikilitic grains may be cordierite.

Biotite-garnet hornfels probably formed from thermal metamorphism of graywacke or closely similar clastic rocks, which are very common in the Meduxnekeag Formation. The large proportion of biotite-garnet hornfels xenoliths in the Estabrook Hill pluton contrasts with the virtual absence of tremolite-diopside hornfels xenoliths here, and suggests that the ribbon rock member was not the immediate source from which the biotite-garnet hornfels formed. A more likely source may be, in part, the slate and graywacke member of the Meduxnekeag Formation, through which the pluton had to be emplaced in order to reach its present position within the ribbon rock member.

\section{ROCKS OF WELLINGTON RIDGE}

The greenish-gray to dark-greenish-gray massive argillite that crops out along the top of Wellington Ridge (pl. 1) is composed mainly of quartz, chlorite, muscovite, and carbonate (locally). Prehnite veinlets, enclosing zoisite(?) laths, cut these rocks at a few

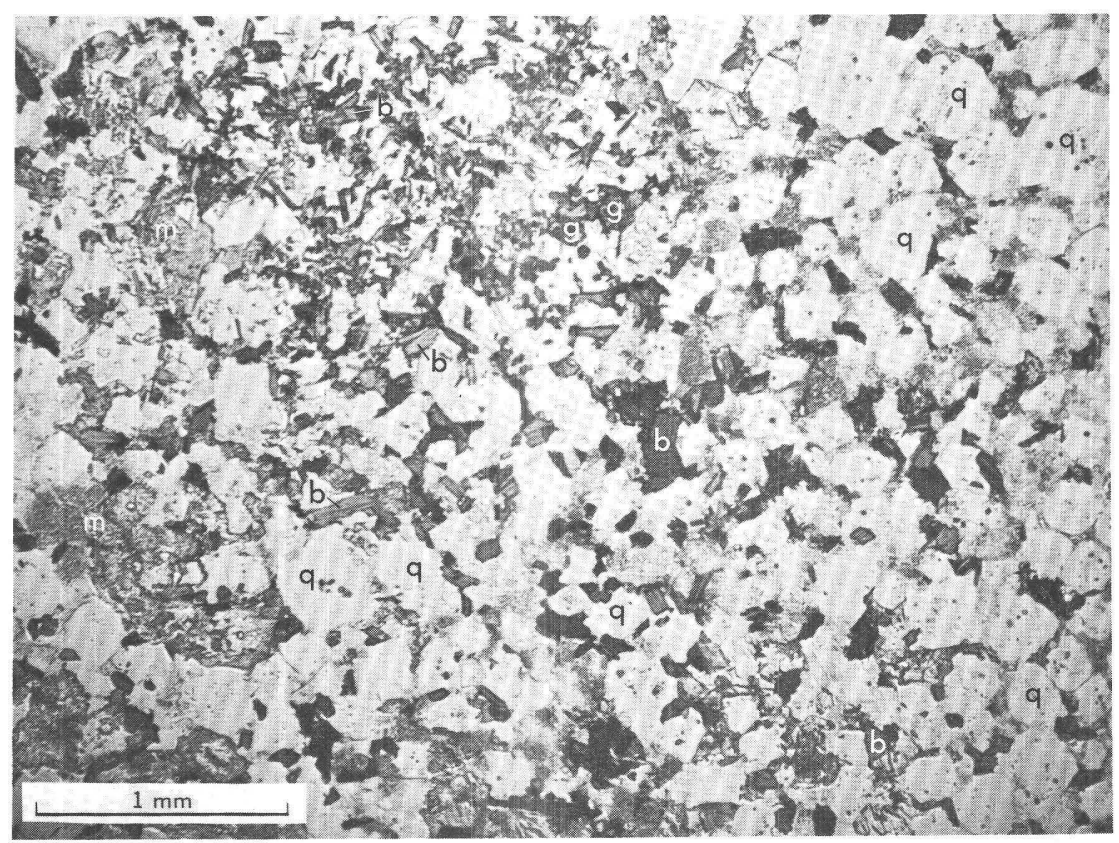

FIGURE 17.-Photomicrograph of spotted hornfels from Estabrook Hill. Note poikilitic habit of quartz (q). Some of these grains may be cordierite. Biotite (b) and garnet (g) occur in a small cluster or knot in upper left. Patchy intergrowths of fine flakes of micaceous minerals (chiefly sericite-muscovite) are present at several places $(m)$. Ordinary light. 
places. Large muscovite flakes occur with inclusions in a few rocks. These rocks are believed to have been thermally metamorphosed, possibly by an unexposed pluton.

\section{ECONOMIC GEOLOGY}

Raw materials obtained from bedrock and surficial deposits in the Bridgewater quadrangle are used only locally and on a small scale. In the past, quartzose limestone of the ribbon rock member of the Meduxnekeag Formation, about 3.8 miles north of Monticello (pl. 2 ), has been quarried and crushed for use as road metal. Sand and gravel have a wider local use in the building and maintaining of county and town roads and access roads on farms. The materials are obtained from glacial outwash, kames, and eskers that underlie the eastern and south-central parts of the region (pl. 2). Similar deposits, as well as glacial till, are used to construct the tote roads in the wooded western part of the quadrangle. Sand and gravel used on county and town roads is generally screened to a desired size whereas farm-access roads and tote roads commonly are constructed of unscreened material taken directly from a pit. Sized sand of local origin is also used on roads in the winter months.

The Maine Geological Survey sampled and analyzed limestone of the ribbon rock member of the Meduxnekeag Formation from three localities in the Bridgewater quadrangle (Bither, 1947, p. 75-76, 86-87) as a possible source for agricultural limestone. None of these samples had neutralizing values in excess of 80 (Trefethen, 1947 , table 6, p. 72) and hence they are not usable even as low-grade agricultural limestone. In parts of northern Maine and in New Brunswick, Canada, marl underlies bogs and swamps that were once the site of glacial lakes. Similar deposits may underlie some of the bogs in the Bridgewater quadrangle and may perhaps be of sufficient purity and quantity for use as agricultural limestone. The costs of prospecting for such deposits are probably high in relation to the possibility of finding any that would be economically exploitable.

Metallic ore minerals have been observed in the Bridgewater quadrangle only in very small quantities. For example, chromite is sparse in the antigoritic serpentine that occurs along the northtrending fault in the northwestern part of the quadrangle. However, a north-trending magnetic anomaly that has a maximum local value of about 3,000 gammas appears to be closely associated with the fault along which the small serpentine masses are found; it may indicate a larger mass of the serpentinite and related rocks at depth.

A small amount of pyrite and a few grains of sphalerite were found in a silicified zone a few feet thick in limy rocks on the north- 
west side of the small greenstone dike exposed along the North Branch Meduxnekeag River southeast of Monticello. A similar silicified zone, but without any visible mineralization, occurs along the west side of the large dacite-diorite dike immediately south of West Road in Monticello Township and along the north wall of a small U-shaped gully locally known as the "Cellar-hole."

\section{GEOPHYSICAL SURVEYS}

By Andrew Griscom and Martin F. Kane

\section{FIELDWORK AND DATA RHDUCTION}

The aeromagnetic survey was made in 1950,1951 , and 1958 as part of a program of aeromagnetic mapping in Maine. Total-intensity aeromagnetic measurements were made with a continuously recording AN/ASQ-3A airborne magnetometer towed about 75 feet below a DC-3 aircraft. Traverse lines were flown approximately 500 feet above the ground at quarter-mile intervals. Both aerial photographs and topographic maps were used for pilot guidance, and the flight path of the aircraft was recorded by a gyrostabilized $35-\mathrm{mm}$ continuous-strip-film camera. The distance from the aircraft to the ground was measured with a continuously recording radar altimeter. The gradient of the earth's normal total magnetic intensity has not been removed from the aeromagnetic map and amounts to an increase of approximately 5 gammas per mile in a northwesterly direction.

Nearly 100 gravity measurements were made in the quadrangle as part of a regional gravity survey of northern Maine (M. F. Kane, D. L. Peterson, and, Howard Sherman, unpub. data). The measurements were made using a Worden gravity meter with a scale factor of about 0.5 milligal per dial division. The gravity values are referred to the base at the Dominion Observatory in Ottawa, Ontario, through a network of gravity bases. The stations were set by standard looping procedures where readings are repeated at a base station within a four-hour interval.

The gravity data are corrected for latitude, elevation, and changes in base readings. A density of $2.67 \mathrm{~g}$ per $\mathrm{cm}^{3}$ was assumed for the elevation correction. The maximum error in the gravity values is caused by a combination of terrain effects and elevation inaccuracies. The maximum error for a single reduced gravity measurement is \pm 2 milligals; however most stations are probably accurate within \pm 1 milligal.

\section{AEROMAGNETIC INTERPRETATION}

The most pronounced magnetic anomaly has an amplitude of nearly 1,000 gammas and is associated with the serpentinite and metagabbro near Collins Ridge in the northwest corner of the 
Bridgewater quadrangle (pl. 3). The anomaly indicates that these intrusions may coalesce at shallow depth and that the concealed intrusive mass trends north-south and is about 1.5 miles long and 0.5 mile wide.

A mile and a half to the south of the serpentinite anomaly is a magnetic high of which only a part lies in the Bridgewater quadrangle. The aeromagnetic map of the Howe Brook quadrangle (Boucot and others, 1964a), indicates that this high may be caused by volcanic rocks in the vicinity of Number Nine Mountain a mile to the west of the Bridgewater quadrangle boundary. Because this anomaly extends more than a mile east of the rock causing the anomaly, it is concluded that the upper surface of the volcanic rock unit probably dips to the east beneath the Meduxnekeag Formation.

A few small anomalies are associated with some of the other igneous rocks of the Bridgewater quadrangle. Minor anomalies are associated with the sills(?) of the Spruce Top Greenstone although some of these may be caused by the volcanic rocks of the Dunn Brook Formation. An extremely small magnetic low is observed over the western garnet porphyry pluton. This anomaly shows as a step on the gentle, east-sloping magnetic gradient in this area. Two 20-gamma anomalies can be correlated with the volcanic rocks on Sugar Loaf in the center of the quadrangle, yet the associated dacite-diorite dike exhibits no anomaly. Very commonly the extrusive equivalents of intrusive rocks possess the higher magnetization.

A gentle, east-sloping magnetic gradient extends roughly along the wetern edge of the quadrangle. To the west, in the Howe Brook quadrangle, this gradient becomes progressively steeper until it ends at the eastern margin of an anomalous pattern (Boucot and others, 1964a) which, according to Pavlides is associated with volcanic rocks. The average width of this gradient is about 7 miles. It very possibly is caused by the volcanic rocks that dip east beneath the Meduxnekeag Formation. A calculation based on an assumed uniform magnetic susceptibility indicates that the surface of the volcanic rocks would have to dip approximately $20^{\circ}$ to the southeast to cause this gradient. This calculated dip in turn indicates that 12,000 to 15,000 feet of sedimentary rocks overlie the vicinity of the 2,000 gamma contour line where it crosses the contact between the Bell Brook and Meduxnekeag Formations.

In the southwest corner of the quadrangle is a broad east trending magnetic high. This feature continues west into the Howe Brook quadrangle where it merges in the central part of that quadrangle with irregular magnetic highs associated with the volcanic rocks mentioned above. The pattern suggests that these volcanic rocks extend out beneath the sedimentary rocks into the Bridgewater 
quadrangle and may here be uplifted slightly by an east trending structure. Owing to some local anomalous structure, the major fold axes of the sedimentary rocks trend northwest only in this part of the quadrangle. Elsewhere a pronounced northeast trend of the magnetic contours generally parallels the trends of the fold axes of the sedimentary rocks.

\section{GRAVITY INTERPRETATION}

Density measurements were made on about 100 typical rock samples (pl. 3) to determine whether the gravity anomalies might be caused by changes in the lithology of the bedrock. The densities of the rocks of the Meduxnekeag Formation, except the slate and graywacke member, averaged about $2.68 \mathrm{~g}$ per $\mathrm{cm}^{3}$. The same average density was measured for the slate member of the Bell Brook Formation. Together these rocks underlie most of the mapped area and their densities may be considered to represent a typical density for the bedrock. The slate and graywacke member of the Meduxnekeag Formation has a measured average density of about $2.63 \mathrm{~g} \mathrm{per} \mathrm{cm}^{3}$. The density difference between this and the other members of the Meduxnekeag Formation is probably caused by the graywacke sandstone. The increase of the feldspar and quartz content $(2.65 \mathrm{~g}$ per $\mathrm{cm}^{3}$ ) implied by the sandstone lithology probably is responsible for the lower density. The quartzite and slate unit of Silurian age in the northwest part of the map also has a density of about $2.63 \mathrm{~g}$ per $\mathrm{cm}^{3}$, and again the quartzite content indicates a relatively high percentage of lower density minerals. The highest densities in the area were measured from rock samples of greenstone from the Spruce Top Greenstone $\left(2.75 \mathrm{~g}\right.$ per $\left.\mathrm{cm}^{3}\right)$ and the metagabbro $\left(2.77 \mathrm{~g} \mathrm{per} \mathrm{cm}^{3}\right)$. The dacite-diorite $\left(2.72 \mathrm{~g}\right.$ per $\left.\mathrm{cm}^{3}\right)$ and the garnet porphyry $(2.69 \mathrm{~g}$ per $\mathrm{cm}^{3}$ ) seem to be only slightly higher in density than the bulk of the sedimentary rocks. Measured rock densities are probably slightly lower than the true densities of rock units because of weathering and porosity effects, but the relative order of densities is believed to be correct.

The gravity features correlate in general with the geologic features; this correlation sugests that the gravity anomalies are caused at least in part by the contrast in densities of the different bedrock lithologies. The trends of the contour lines tend to follow the structural trends of the rock units. The most conspicuous feature of the gravity field is a low which extends from the south along the west edge of the Bridgewater quadrangle and then trends northeast into the north-central part of the quadrangle. The maximum amplitude of this feature is greater than 10 milligals. The trends 
of the contour lines on the west side of the low are determined in part from data obtained in the Howe Brook quadrangle.

In the southwestern part of the quadrangle, the major gravity low correlates most closely with the slate member of the Bell Brook Formation. The measured average density of this rock unit is $2.68 \mathrm{~g}$ per $\mathrm{cm}^{3}$, however, the same as that of the average bedrock; hence, the anomaly seems to be caused by a buried rock mass. Two possible causes for the anomaly are: (1) a thick quartzite section (density about $2.65 \mathrm{~g}$ per $\mathrm{cm}^{3}$ ) which would have to have a thickness in excess of 10,000 feet or, (2) a felsic intrusion (density about $2.65 \mathrm{~g}$ per $\mathrm{cm}^{3}$ ). A thick section of low-density sedimentary rocks is unlikely in this area and there is no other evidence for it. The correlation of gravity lows and felsic intrusions is well established (Bott, 1956), and it has been shown to hold true in west-central Maine (Kane and Peterson, 1961). In addition, the low in the Bridgewater quadrangle is the northward extension of an anomaly which originates to the south in the Smyrna Mills quadrangle over the felsic Hunt Ridge pluton of Devonian age that crops out at the surface (Pavlides and Canney, 1964). Gravity gradients (Bott, 1956) show that the gravity anomaly in the Smyrna Mills quadrangle is caused by the felsic intrusion. In the Bridgewater quadrangle two garnet porphyry plutons and the metamorphosed area at Wellington Ridge occur along the gravity low. Another garnet porphyry pluton crops out in the Howe Brook quadrangle, according to Pavlides, at lat $46^{\circ} 20^{\prime}$ N. 1 mile west of the Bridgewater quadrangle boundary.

The combined evidence suggests the presence of a felsic intrusion at depth along the western part of the Bridgewater quadrangle. The gravity gradients of the anomaly are low, and indicate that the mass is deeply buried or that its contacts are gently dipping. The intrusion presumably lies deeper than the 12,000-to-15,000-foot depth inferred from the magnetic gradient, inasmuch as it would interfere with the gradient if present at a shallower depth.

The northern extension of the gravity low lies over the eastern margin of the slate and graywacke member of the Meduxnekeag For-

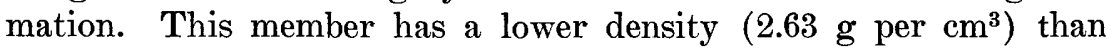
the ribbon rock member $\left(2.68 \mathrm{~g}\right.$ per $\left.\mathrm{cm}^{3}\right)$ which adjoins it to the east. Part of the gravity low may be caused by this contrast in densities. Similarly the gravity high to the northwest is located near the eastern margin of the block containing the denser greenstone of the Spruce Top Greenstone $\left(2.75 \mathrm{~g}\right.$ per $\left.\mathrm{cm}^{3}\right)$. If these anomalies were assumed to be caused entirely by the contrasting densities of other rock units described above, the easterly offset of the anomaly peaks would imply eastern or southeastern dips for the contacts of 
the units. However, the gravity anomaly caused by an intrusion at depth makes any such implication highly uncertain.

The low gravity values in the extreme northwest are probably caused by the low density of the quartzite and slate unit of Silurian age. A very small gravity high (less than a milligal) is present over the dacite-diorite dike near Harvey. The anomaly suggests, as did the measured densities, that the dike rock has a slightly higher density than the ribbon rock member of the Meduxnekeag Formation.

\section{REFERENCES}

Béland, Jacques, 1958, Preliminary report on the Oak Bay area : Quebec Dept. Mines Prelim. Rept. 375, 12 p.

Bither, R. A., 1947, Notes on Aroostook limestone locations: Maine Devel. Comm. State Geologists Rept. 1945-46, p. 73-98.

Bott, M. H. P., 1956, A geophysical study of the granite problem: Geol. Soc. London Quart. Jour., v. 112, pt. 1, no. 445, p. 45-67.

Boucot, A. J., Griscom, Andrew, Allingham, J. W., and Dempsey, W. J., 1964a, Geologic and aeromagnetic map of Maine: U.S. Geol. Survey Geophys. Inv. Map GP-312.

Boucot, A. J., Field, M. T., Fletcher, Raymond, Forbes, W. A., Naylor, R. S., and Pavlides, Louis, 1964b, Reconnaissance bedrock geology of the Presque Isle quadrangle, Maine: Maine Geol. Survey Quad. Mapping Ser., no. 2, $123 \mathrm{p}$.

Deevey, E. S., Jr., 1951, Late-glacial and postglacial pollen diagrams from Maine: Am. Jour. Sci., v. 249, p. 177-207.

Eakins, P. R., 1962, The western Appalachians of southern Quebec, in New England Intercollegiate Geol. Conf. Guidebook, 54th Ann. Meeting, Montreal: Montreal, Quebec, McGill Univ., p. 81-94.

Ekren, E. B., 1961, Volcanic rocks of Ordovician age in the Mount Chase ridge, Island Falls quadrangle, Maine: U.S. Geol. Survey Prof. Paper 424-D, art. 309, p. D43-D46.

Faul, Henry, Stern, T. W., Thomas, H. H., and Elmore, P. L. D., 1963, Ages of intrusion and metamorphism in the northern Appalachians: Am. Jour. Sci., v. 261, p. 1-19.

Flint, R. F., 1953, Probable Wisconsin substages and Late-Wisconsin events in northeastern United States and southeastern Canada: Geol. Soc. America Bull., v. 64, p. 897-920.

Fyfe, W. S., Turner, F. J., and Verhoogen, Jean, 1958, Metamorphic reactions and metamorphic facies: Geol. Soc. America Mem. 73, $259 \mathrm{p}$.

Groom, Theodore, 1902, The sequence of the Cambrian and associated beds of the Malvern Hills: Geol. Soc. London Quart. Jour., v. 58, p. 89-135.

Haaf, E. ten, 1956, Significance of convolute laminations: Geologie en Mijnbouw, v. 18, p. 188-194.

Hanley, J. B., 1959, Surficial geology of the Poland quadrangle, Maine: U.S. Geol. Survey Geol. Quad. Map GQ-120.

Henderson, J. R., 1962, Aeromagnetic map of the Bridgewater quadrangle, Maine: U.S. Geol. Survey Geophys. Inv. Map GP-291.

Kane, M. F., and Peterson, D. L., 1961, Preliminary interpretation of gravity data in west-central Maine: U.S. Geol. Survey open-file report.

Kuenen, Ph. H., 1953a, Significant features of graded bedding: Am. Assoc. Petroleum Geologists Bull., v. 37, no. 5, p. 1044-1066. 
Kuenen, Ph. H., 1953b, Graded bedding, with observations on Lower Paleozoic rocks of Britain: Koninkl. Nederlandse Akad. Wetensch., Afd Natuurk. Verh., 'ser. 1, pt. 20, no. 3, p. 1-47.

Miller, R J., 1947, Manganese deposits of Aroostook County, Maine: Maine Geol. Survey Bull. 4, p. 1-77.

Neuman, R. B., 1964, Fossils in Ordovician tuff, northeastern Maine: U.S. Geol. Survey Bull. 1181-E, p. E1-E38.

Pavlides, Louis, 1962, Geology and manganese deposits of the Maple and Hovey Mountains area, Aroostook County, Maine, with a section on Lithology and mineralogy of the deposits, by Louis Pavlides and Charles Milton: U.S. Geol. Survey Prof. Paper 362, 116 p. [1963].

1964, The Hovey Group in northeastern Maine: U.S. Geol. Survey Bull. 1194-B, p. B1-B6.

Pavlides, Louis, and Canney, F. C., 1964, Geological and geochemical reconnaissance, southern part of the Smyrna Mills quadrangle, Aroostook County, Maine: U.S. Geol. Survey Prof. Paper 475-D, p. D96-D99.

Pavlides, Louis, Mencher, Ely, Naylor, R. G., and Boucot, A. J., 1964, Tectonic features of eastern Aroostook County, Maine: U.S. Geol. Survey Prof. Paper 501-C, p. C28-C38.

Pavlides, Louis, Neuman, R. B., and Berry, W. B. N., 1961, Age of the ribbon rock of Aroostook County, Maine: U.S. Geol. Survey Prof. Paper 424-B, p. B65-B67.

Penau, Joseph, 1941, Die Anwesenheit von Tomaculum problematicum im Ordovicium West-Frankreichs: Senckenbergiana, v. 23, p. 127-132.

Rich, J. L., 1950, Flow markings, groovings, and intrastratal crumplings as criteria for recognition of slope deposits, with illustrations from the Silurian rocks of Wales: Am. Assoc. Petroleum Geologists Bull., v. 34, p. 717741.

Ross, C. S., and Smith, R L., 1961, Ash-flow tuffs: their origin, geologic relations, and identification: U.S. Geol. Survey Prof. Paper 366, 81 p.

Tauber, Henrik, 1960a, Copenhagen natural radiocarbon measurements III, correction to radiocarbon dates made with the solid carbon technique: Radiocarbon, v. 2, p. 5-11.

1960b, Copenhagen radiocarbon dates IV: Radiocarbon, v. 2, p. 12-25.

Trefethen, J. M., 1947, Limestone: Maine Devel. Comm. State Geologist Rept. 1945-46, p. 66-72.

White, W. S., 1943, Occurrence of manganese in eastern Aroostook County, Maine: U.S. Geol. Survey Bull. 940-E, p. 126-161.

White, W. S., and Jahns, R. H., 1950, Structure of central and east-central Vermont: Jour. Geology, v. 58, p. 179-220.

Williams, H. S., and Gregory, H. E., 1900, Contributions to the geology of Maine; U.S. Geol. Survey Bull. 165, p. 1-212.

Williams, Howell, Turner, F. J., and Gilbert, C. M., 1954, Petrography: San Francisco, Calif., W. H. Freeman and Company, p. 1-406. 


\section{INDEX}

[Italic page numbers indicate major references]

\begin{tabular}{|c|c|}
\hline Page & age \\
\hline Abstract_. & Geophysical fieldwork. \\
\hline eromagnetic & Alacial drift. \\
\hline 46 & undifferentiated. \\
\hline & Wi \\
\hline on Ridge..- & $\begin{array}{l}\text { Glacial events, summary } \\
\text { Glacial outwash... }\end{array}$ \\
\hline ell Broc & lding, Bell Brook Formation.....- \\
\hline 29 & 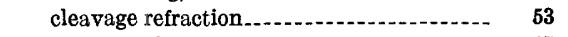 \\
\hline 28 & ne...... \\
\hline 68 & Grap \\
\hline 30,67 & 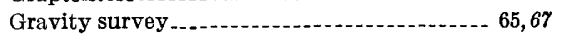 \\
\hline 62 & Brook Formation... \\
\hline ekeag Formation & Formation.... $7,9,12$ \\
\hline$\cdots$ & 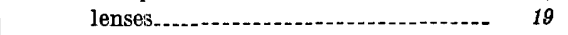 \\
\hline$-\cdots$ & - \\
\hline$\cdots$ & alyses_..-.....-. \\
\hline$\cdots$ & 58,60 \\
\hline - & \\
\hline nstone & $-61,62$ \\
\hline - & - \\
\hline$\ldots$ & e Lake I \\
\hline of Bell Brook Forma- & $\ldots$ \\
\hline$-\cdots$ & 45 \\
\hline 16 & 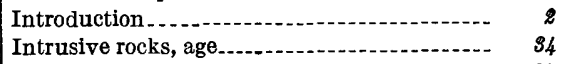 \\
\hline 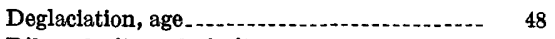 & a \\
\hline rite_............ & \\
\hline 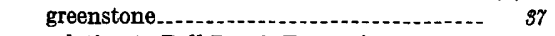 & 49 \\
\hline ion.......... & (n) \\
\hline 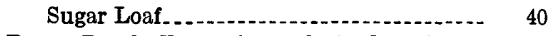 & \\
\hline tion, admixed sedimen- & 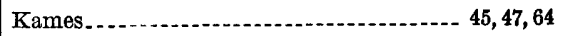 \\
\hline 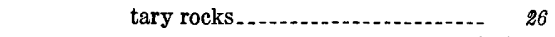 & 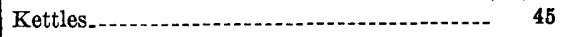 \\
\hline-8 & \\
\hline$\cdots-$ & bi \\
\hline 26 & $\mathrm{n}$ \\
\hline 34 & n \\
\hline s, fine-graine & Q Top Greenstone....................... \\
\hline 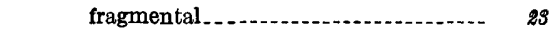 & \\
\hline 57,66 & \\
\hline & \\
\hline 64 & $-\cdots$ \\
\hline & rmation, age..... 21, 58 \\
\hline (n) & 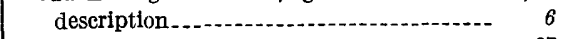 \\
\hline$\ldots 43,45,4$ & tures...... \\
\hline$-62,63$ & nber \\
\hline & $\begin{array}{lr}\text { imestone } & 15 \\
\text { vacke member } & \end{array}$ \\
\hline 56 & \\
\hline & Meduxnekeag River, North Branch, diver- \\
\hline ........ & eristina. \\
\hline
\end{tabular}




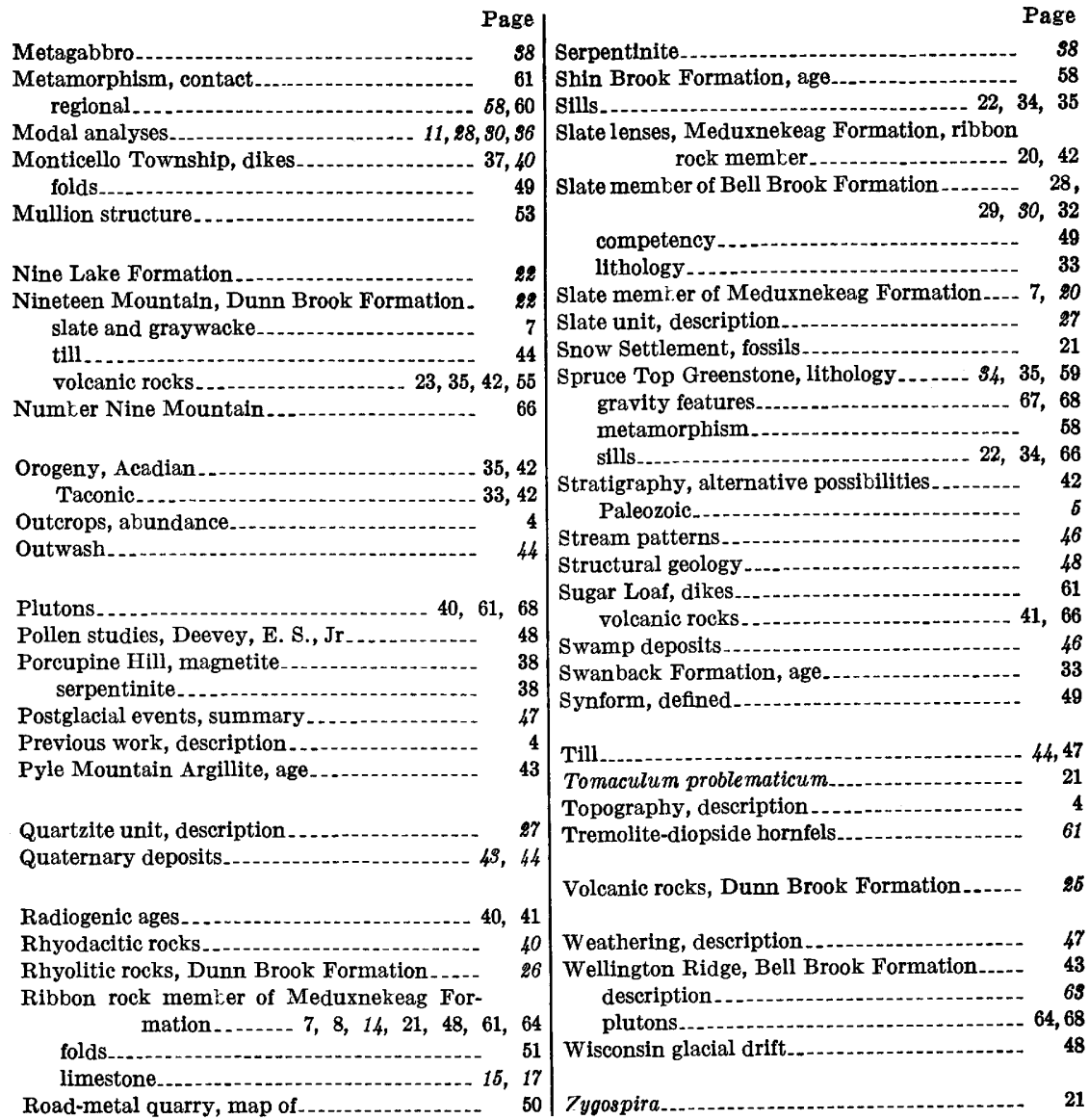



